\title{
WATER-QUALITY ASSESSMENT OF THE OZARK PLATEAUS STUDY UNIT, ARKANSAS, KANSAS, MISSOURI, AND OKLAHOMA - SUMMARY OF INFORMATION ON PESTICIDES, 1970-90
}

U.S. GEOLOGICAL SURVEY

Water-Resources Investigations Report 96-4003

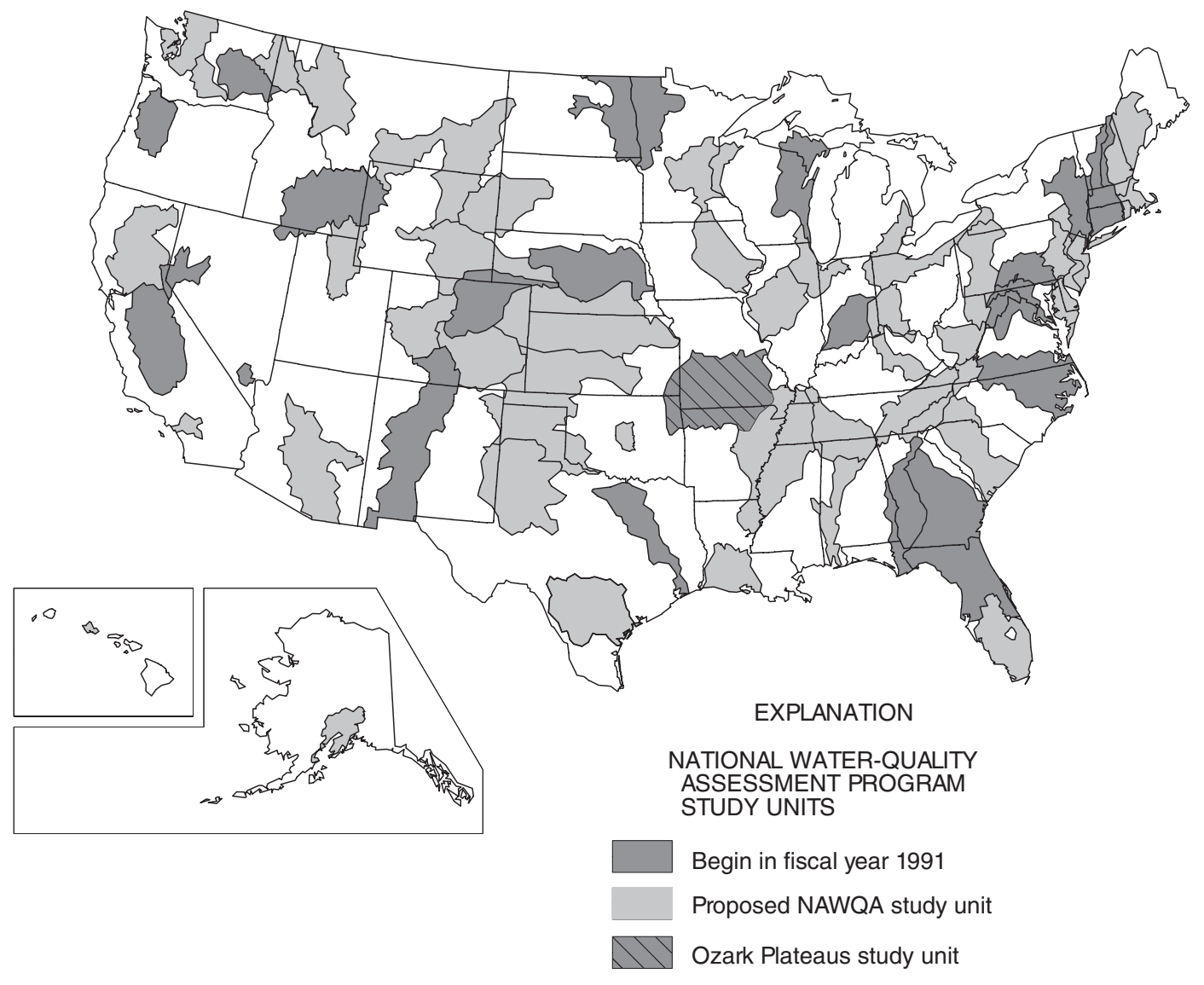

National Water-Quality Assessment Program 


\section{WATER-QUALITY ASSESSMENT OF THE OZARK PLATEAUS STUDY UNIT, ARKANSAS, KANSAS, MISSOURI, AND OKLAHOMA-SUMMARY OF INFORMATION ON PESTICIDES, 1970-90}

By Richard W. Bell, Robert L. Joseph, and David A. Freiwald

U.S. GEOLOGICAL SURVEY

Water-Resources Investigations Report 96-4003

National Water-Quality Assessment Program 


\section{U.S. DEPARTMENT OF THE INTERIOR}

BRUCE BABBITT, Secretary

\section{U.S. GEOLOGICAL SURVEY}

Gordon P. Eaton, Director

For additional information write to:

\section{District Chief}

U.S. Geological Survey, WRD

401 Hardin Road

Little Rock, Arkansas 72211
Copies of this report can be purchased from:

U.S. Geological Survey

Branch of Information Services

Box 25286

Denver Colorado 80225

Information regarding the National Water-Quality Assessment (NAWQA) Program is available on the Internet via the World Wide Web. You may connect to the NAWQA Home Page using the Universal Resource Locator (URL) at:

<URL:http://wwwrvares.er.usgs.gov/nawqa_home.html> 


\section{FOREWORD}

The mission of the U.S. Geological Survey (USGS) is to assess the quantity and quality of the earth resources of the Nation and to provide information that will assist resource managers and policymakers at Federal, State, and local levels in making sound decisions. Assessment of water-quality conditions and trends is an important part of this overall mission.

One of the greatest challenges faced by waterresources scientists is acquiring reliable information that will guide the use and protection of the Nation's water resources. That challenge is being addressed by Federal, State, interstate, and local water-resource agencies and by many academic institutions. These organizations are collecting water-quality data for a host of purposes that include: compliance with permits and water-supply standards; development of remediation plans for a specific contamination problem; operational decisions on industrial, wastewater, or watersupply facilities; and research on factors that affect water quality. An additional need for water-quality information is to provide a basis on which regional and national-level policy decisions can be based. Wise decisions must be based on sound information. As a society we need to know whether certain types of water-quality problems are isolated or ubiquitous, whether there are significant differences in conditions among regions, whether the conditions are changing over time, and why these conditions change from place to place and over time. The information can be used to help determine the efficacy of existing waterquality policies and to help analysts determine the need for and likely consequences of new policies.

To address these needs, the Congress appropriated funds in 1986 for the USGS to begin a pilot program in seven project areas to develop and refine the National Water-Quality Assessment (NAWQA) Program. In 1991, the USGS began full implementation of the program. The NAWQA Program builds upon an existing base of water-quality studies of the USGS, as well as those of other Federal, State, and local agencies. The objectives of the NAWQA Program are to:

-Describe current water-quality conditions for a large part of the Nation's freshwater streams, rivers, and aquifers.

-Describe how water quality is changing over time.
-Improve understanding of the primary natural and human factors that affect water-quality conditions.

This information will help support the development and evaluation of management, regulatory, and monitoring decisions by other Federal, State, and local agencies to protect, use, and enhance water resources.

The goals of the NAWQA Program are being achieved through ongoing and proposed investigations of 60 of the Nation's most important river basins and aquifer systems, which are referred to as study units. These study units are distributed throughout the Nation and cover a diversity of hydrogeologic settings. More than two-thirds of the Nation's freshwater use occurs within the 60 study units and more than twothirds of the people served by public water-supply systems live within their boundaries.

National synthesis of data analysis, based on aggregation of comparable information obtained from the study units, is a major component of the program. This effort focuses on selected water-quality topics using nationally consistent information. Comparative studies will explain differences and similarities in observed water-quality conditions among study areas and will identify changes and trends and their causes. The first topics addressed by the national synthesis are pesticides, nutrients, volatile organic compounds, and aquatic biology. Discussions on these and other waterquality topics will be published in periodic summaries of the quality of the Nation's ground and surface water as the information becomes available.

This report is an element of the comprehensive body of information developed as part of the NAWQA Program. The program depends heavily on the advice, cooperation, and information from many Federal, State, interstate, Tribal, and local agencies and the public. The assistance and suggestions of all are greatly appreciated. 


\section{CONTENTS}

Abstract

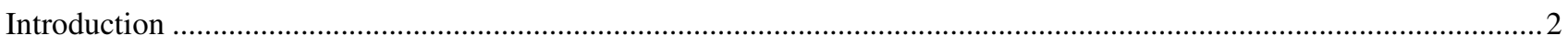

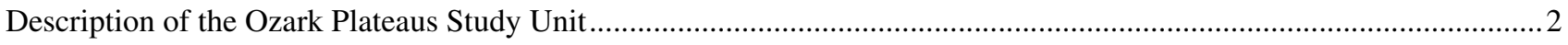

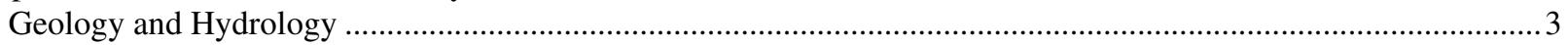

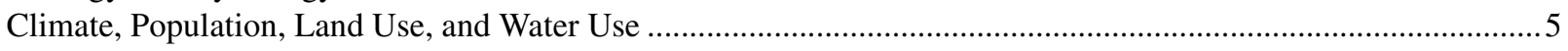

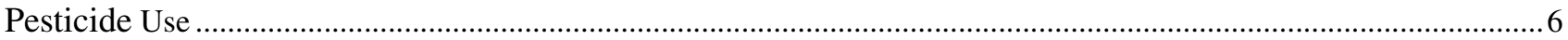

Sources of Water-Quality, Bed-Sediment, and Biological-Tissue Data ...................................................................

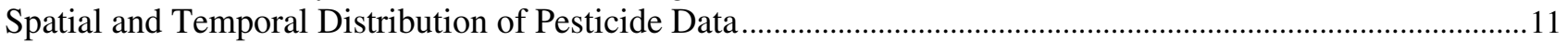

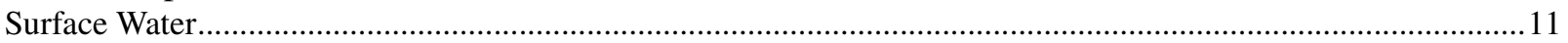

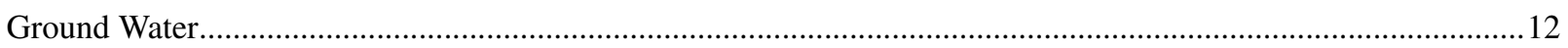

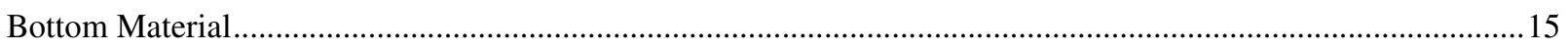

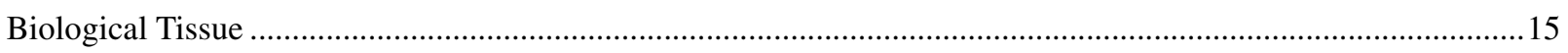

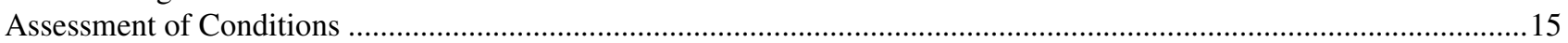

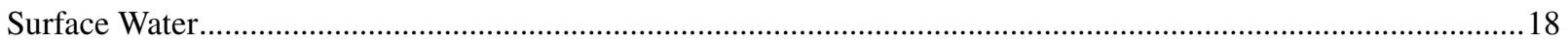

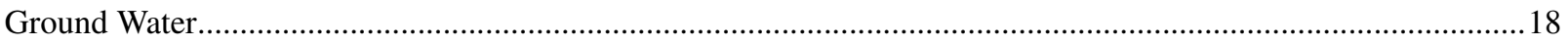

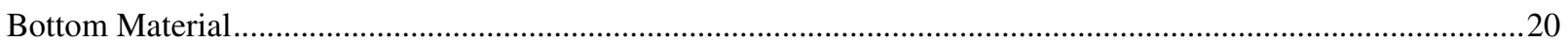

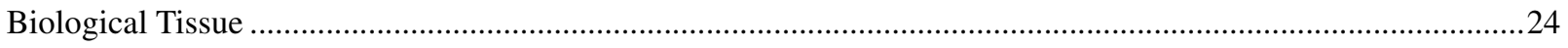

Comparison of Pesticide Data with Selected Quality Criteria .......................................................................26

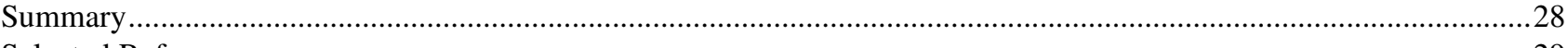

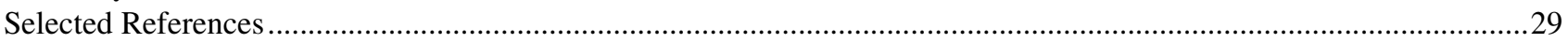

\section{ILLUSTRATIONS}

1-8. Maps showing:

1. Location of Ozark Plateaus study unit, major river basins, physiographic areas, and surface extent

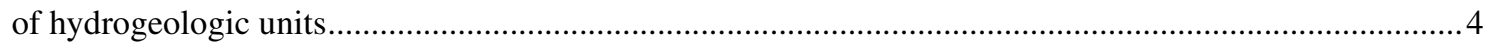

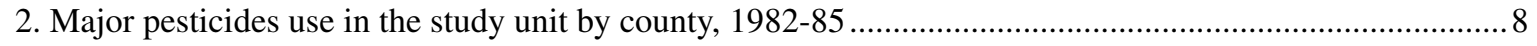

3. Pesticide application rate for counties within in the study unit .............................................................

4. Crop types receiving the largest pesticide applications for counties within the study unit ........................10

5. Location of surface-water pesticide sampling sites and sites where pesticides were detected....................13

6. Location of ground-water pesticide sampling sites and sites where pesticides were detected .....................14

7. Location of bed-sediment pesticide sampling sites and sites where pesticides were detected ....................16

8. Location of biological-tissue pesticide sampling sites and sites where pesticides were detected ................17

\section{TABLES}

1. Land-use percentage by physiographic area …....................................................................................

2. Estimated pesticide applications in the study unit, 1982-85, and description of pesticide type and use..............7

3. Major pesticide data sources available for the study unit ...........................................................................11

4. Summary of number of pesticide sampling sites and samples collected for each sample type, by agency........12

5. Site and basin characteristics of surface-water sampling sites .......................................................................... 
6. Site characteristics of ground-water sampling sites 39

7. Site and basin characteristics of bed-sediment sampling sites ............................................................... 43

8. Site and basin characteristics of biological-tissue sampling sites .................................................................46

9. Statistical summary of pesticide data from surface-water sampling sites for water years $1970-90 \ldots \ldots \ldots \ldots \ldots . . . . .19$

10. Statistical summary of pesticide data from ground-water sampling sites for water years $1970-90 \ldots \ldots \ldots \ldots \ldots . . . .21$

11. Statistical summary of pesticide data from bed-sediment sampling sites for water years $1970-90 \ldots \ldots \ldots \ldots \ldots \ldots . . . . . .23$

12. Statistical summary of pesticide data from biological-tissue sampling sites for water years $1970-90 \ldots \ldots \ldots \ldots . . .25$

13. Comparison of selected quality criteria and standards with maximum detected concentrations in surface-water, ground-water, bed-sediment, and biological-tissue samples 


\section{WATER-QUALITY ASSESSMENT OF THE OZARK PLATEAUS STUDY UNIT, ARKANSAS, KANSAS, MISSOURI, AND OKLAHOMA — SUMMARY OF INFORMATION ON PESTICIDES, 1970-90}

By Richard W. Bell, Robert L. Joseph, and David A. Freiwald

\begin{abstract}
Historical pesticide data from 1970-90 were compiled for 140 surface-water, 92 groundwater, 55 streambed- sediment, and 120 biological-tissue sampling sites within the Ozark Plateaus National Water Quality Assessment Program study unit. Surface-water, bed-sediment, and biological-tissue sites have drainage basins predominantly in the Springfield and Salem Plateaus; ground-water sites are predominantly located in the Osage Plains and Mississippi Alluvial Plain. Many sites were sampled only once or twice during this period. A large percentage of the samples was collected in the mid-1970's and early 1980's for surface-water, 1990 for ground water, the late 1980 's for bed sediment, and the early 1980's for biological tissue.
\end{abstract}

Pesticide use was approximately 4.2 million pounds per year of active ingredients from 198285 in the study unit and was generally greatest in the Salem and Springfield Plateaus pasturelands and in the Osage Plains and Mississippi Alluvial Plain cropland areas. The most frequently applied pesticide in the study unit was 2,4-D. Alachlor was the second most applied pesticide. Corn, pasture, rice, sorghum, and soybeans received approximately 90 percent of the pesticides applied within the study unit. The highest pesticide application rate per acre occurred on these crops in the Mississippi Alluvial and Osage Plains. Pastureland was the predominant crop type in 50 of the 94 counties in the study unit.

Toxaphene, the pesticide having the most number of detections in surface water, was found in 17 of 866 samples from 5 of 112 sites. Concentrations ranged from 0.1 to 6.0 micrograms per liter. Six other pesticides or pesticide metabolites were detected in 12 or more surface-water samples: DDE, dieldrin, DDT, aldrin, 2,4-D, and lindane. The maximum concentration for these pesticides was less than 1.0 micrograms per liter.

Atrazine, the pesticide having the most number of detections in ground water, was found in 15 of 95 samples from 15 of 79 wells with concentrations ranging from 0.1 to 8.2 micrograms per liter. Metolachlor, alachlor, and prometon were detected more than once with maximum concentrations less than 1.0 micrograms per liter, except for prometon (2.4 micrograms per liter).

Chlordane was the pesticide having the most number of detections in bed sediment and biological tissue. Chlordane was detected in 12 of 73 samples from 10 of 45 bed-sediment sites with concentrations ranging from 2.0 to 240 micrograms per kilogram. In biological tissue, chlordane was found in 93 of 151 samples from 39 of 53 sites with concentrations ranging from 0.009 to 8.6 milligrams per kilogram. Other pesticides or pesticide metabolites detected more than once in bed sediment include DDT, DDD, p,p'-DDE, DDE, 
and hexachlorobenzene and in biological tissue include DDT, p,p'-DDE, and hexachlorobenzene.

Quality criteria or standards have been established for 15 of the pesticides detected in the study unit. For surface-water samples, the drinking water maximum contaminant level for alachlor was exceeded in one sample from one site in 1982. For ground-water samples, the drinking water maximum contaminant level for atrazine was exceeded in four samples from four wells in 1990. For biological-tissue samples collected during the years 1982-89, the fish tissue action levels for chlordane (26 samples, 19 sites), heptachlor epoxide ( 3 sites; 3 samples), p,p'-DDE (2 sites; 2 samples), dieldrin (2 sites; 2 samples), and mirex (1 site; 1 sample) were exceeded. For bed-sediment samples, quality criteria or standards were not exceeded for any pesticide. Pesticides do not pose any widespread or persistent problems in the study unit, based on the limited number of samples that exceeded quality criteria and standards.

\section{INTRODUCTION}

In 1991, the U.S. Geological Survey (USGS) began full implementation of the National WaterQuality Assessment (NAWQA) Program to provide a nationally consistent description of water-quality conditions for a large part of the Nation's water resources. The long-term goals of the NAWQA Program are to describe the status and trends in the quality of the Nation's surface- and ground-water resources and to provide a better understanding of the natural and human factors that affect the quality of these resources. Investigations will be conducted on a rotational basis in 60 river basins or aquifer systems (referred to as study units) throughout the Nation.

Regional and national synthesis of information from the study units will be the foundation for the comprehensive assessment of the Nation's water quality. Information on water quality, and factors such as climate, geology, hydrology, land use, and agricultural practices, will be integrated to focus on specific water-quality issues that affect large contiguous hydrologic regions. For example, a concern addressed first in the program is the retrospective analysis of existing data on pesticides, nutrients, and suspended sediment as part of the national synthesis activities, which contribute to answering fundamental waterquality questions facing the Nation.

In 1991, the Ozark Plateaus NAWQA study unit was among the first 20 study units selected for assessment under the full implementation plan. The complex, mostly karst aquifer system of the Ozark Plateaus study unit, coupled with the influx of people and the probability of future population and agricultural growth, makes this area extremely susceptible to water-resources degradation. The study unit investigation will consist of 5 years (1991-95) of intensive assessment, followed by 5 years (1996-2000) of lowlevel monitoring, and then the cycle will be repeated. Each 5-year assessment period will include about 2 years of retrospective analysis and planning and 3 years of intensive-data collection.

The purpose of this report is to summarize several types of pesticide information for the study unit: pesticide- use data, spatial and temporal availability of pesticide data, and an assessment of recent (1970-90) conditions. This information will be used as a guide for additional data-collection activities. Also, information provided in this report will contribute to national synthesis activities that will compare and contrast water quality in similar and different environments throughout the Nation.

This report includes (1) a brief overview of the environmental setting of the study unit; (2) a summary of pesticide-use data for 1982-85; (3) a description of the sources of available pesticide data; (4) a description of the spatial and temporal distribution of pesticides and pesticide metabolites in surface-water, ground-water, streambed- sediment, and biologicaltissue samples; and (5) an assessment of conditions using statistical summaries of pesticide and pesticide metabolite data collected during water years (October 1 through September 30) 1970-90.

\section{DESCRIPTION OF THE OZARK PLATEAUS STUDY UNIT}

This section of the report describes the environmental setting of the study unit. The environmental setting characteristics from Davis and others (1995) that are most important to the discussion of pesticides will be discussed here. For more detail, the reader is referred to the environmental setting report for the study unit (Adamski and others, 1995). 
The Ozark Plateaus study unit area encompasses approximately 48,000 square miles $\left(\mathrm{mi}^{2}\right)$ and includes parts of northern Arkansas, southeastern Kansas, southern Missouri, and northeastern Oklahoma (fig. 1). The study unit includes most of the Ozark Plateaus Province as well as parts of the surrounding Central Lowland Province known as the Osage Plains section, and a small portion of the Mississippi Alluvial Plain section of the Coastal Plain Province (Fenneman, 1938).

The Ozark Plateaus Province consists of a structural dome of sedimentary and igneous rocks. Sedimentary rocks gently dip away from the igneous core of the St. Francois Mountains in southeastern Missouri to form three distinct physiographic sections (Fenneman, 1938)--the Salem Plateau (includes the St. Francois Mountains), the Springfield Plateau, and the Boston Mountains (fig. 1). Topography varies from mostly gently rolling hills in the Springfield Plateau, to rugged with relief up to 500 feet $(\mathrm{ft})$ in the Salem Plateau, to extremely rugged with relief as much as $1,000 \mathrm{ft}$ in the Boston Mountains. The Osage Plains of the Central Lowland Province in the westnorthwestern part of the study unit has gently rolling topography with relief rarely exceeding $250 \mathrm{ft}$. The Mississippi Alluvial Plain of the Coastal Plain Province along the extreme southeastern boundary of the study unit has flat to gently rolling topography with little relief.

The St. Francois Mountains area is not a separate physiographic section as defined by Fenneman (1938), but will be discussed in this report separately because of its unique hydrogeologic features. For the purposes of this report, the physiographic sections described above and the St. Francois Mountains will hereinafter be referred to as physiographic areas.

\section{Geology and Hydrology}

The Ozark Plateaus study unit consists of basement igneous rocks of Precambrian age overlain by as much as 5,000 ft of gently-dipping sedimentary rocks of Paleozoic age (Imes and Emmett, 1994). The igneous rocks include granite, rhyolite, and diabase and form the core of the St. Francois Mountains. In the Salem Plateau, sedimentary rocks of Cambrian and Ordovician age consist of dolomite, sandstone, and limestone with minor amounts of shale. Most of the rocks of Mississippian age in the Springfield Plateau are cherty limestones. Sedimentary rocks of Pennsylvanian age in the Osage Plains and Boston Mountains consist of shale, sandstone, and limestone. Lead-zinc deposits are present in the rocks of Cambrian through Mississippian age near the St. Francois Mountains and in the tri-State area of Kansas, Missouri, and Oklahoma. Coal deposits are present in the rocks of Pennsylvanian age along the northwestern study unit boundary. The rocks in the study unit have been fractured and faulted as a result of uplifting.

The study unit is divided into seven hydrogeologic units consisting of three major aquifers and four confining units (Imes and Emmett, 1994) (fig. 1). These units, from youngest to oldest, are: the Western Interior Plains confining system, the Springfield Plateau aquifer, the Ozark confining unit, the Ozark aquifer, the St. Francois confining unit, the St. Francois aquifer, and the Basement confining unit. The unconsolidated sediments of the Mississippi River Valley alluvial aquifer form an eighth aquifer, of limited areal extent within the study unit.

The Springfield Plateau and Ozark aquifers are thick sequences of limestones and dolomites with secondary permeability resulting from the fracture and dissolution of the carbonate rocks. Where the Springfield Plateau aquifer is unconfined (coincident with the Springfield Plateau physiographic area) it is extensively used as a source of water for domestic supplies, with well yields averaging less than 20 gallons per minute ( $\mathrm{gal} / \mathrm{min}$ ). The Ozark aquifer is used where it is both unconfined (coincident with the Salem Plateau physiographic area) and confined for public supply and domestic use, with well yields generally ranging from 50 to $100 \mathrm{gal} / \mathrm{min}$ but which can be as much as $600 \mathrm{gal} / \mathrm{min}$. The St. Francois aquifer consists of sandstones and dolomites, with well yields as much as $500 \mathrm{gal} / \mathrm{min}$, although the aquifer is rarely used where overlain by the thicker Ozark aquifer.

The Western Interior Plains confining system (coincident with the Boston Mountains and Osage Plains physiographic areas) consists of relatively permeable sandstone and limestone beds separated by thick layers of impermeable shale beds. The confining system has low permeability relative to the Springfield Plateau and Ozark aquifers, but is used locally as a source of water for domestic supplies with well yields ranging from 1 to $40 \mathrm{gal} / \mathrm{min}$. The Ozark and St. Francois confining units consist mostly of shales and dense limestones or dolomites. These confining units hydraulically separate the overlying and underlying aquifers. The Basement confining unit underlies the study unit and consists mostly of igneous rocks. 


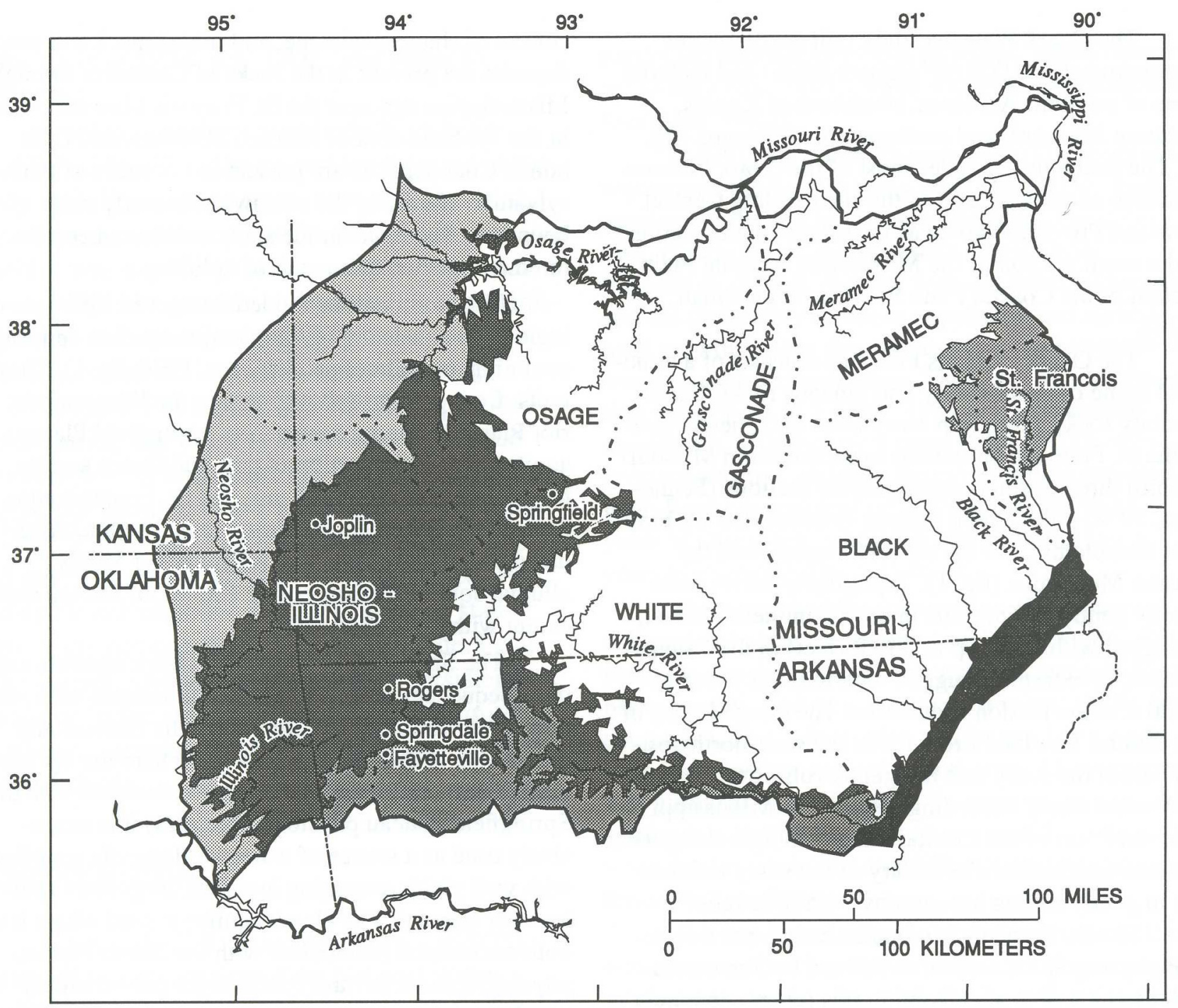

EXPLANATION

PHYSIOGRAPHIC AREA HYDROGEOLOGIC UNIT

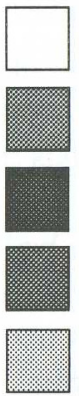

-
Salem Plateau/Ozark confining unit and aquifer

St. Francois Mountains/St. Francois confining unit and aquifer

Springfield Plateau/Springfield Plateau aquifer

Boston Mountains/Westem Interior Plains confining system

Osage Plains/Westem Interior Plains confining system

Mississippi Aluvial Plain/Mississippi River Valley alluvial aquifer

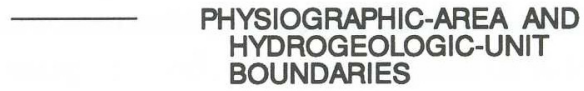

$\ldots . . . \quad$ BASIN BOUNDARY

STUDY-UNIT BOUNDARY

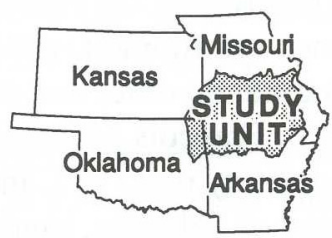


The Ozark Plateaus study unit is drained by seven major rivers--the White, Neosho-Illinois, Osage, Gasconade, Meramec, Black, and St. Francis Rivers (fig. 1)--which flow directly or indirectly into the Mississippi River. Many large reservoirs have been constructed on the White, Osage, and Neosho Rivers.

Stream gradients are steepest in the Boston and St. Francois Mountains and flattest in the Osage Plains and Mississippi Alluvial Plain. Channel-bed material ranges from clay and silt in the Osage Plains to sand, gravel, boulders, and bedrock in most of the Ozark Plateaus Province. Streams in the Osage Plains are turbid, with long pools separated by poorly defined riffles. Streams in the Ozark Plateaus Province are mostly clear, with pools separated by riffles, and in places, cascading waterfalls.

Mean annual runoff generally increases from the north to the south (Gebert and others, 1985). Mean annual runoff is least in the northern Osage Plains, ranging from 9 to 10 inches (in.); increases in the Springfield and Salem Plateaus, ranging from 10 to 16 in.; and is greatest in the Boston Mountains, ranging from 14 to $20 \mathrm{in.}$

Minimum monthly streamflows generally occur in the summer and early fall and maximum monthly streamflows typically occur in the late winter and spring. Maximum monthly streamflows generally coincide with the period of maximum precipitation and minimum evapotranspiration.

\section{Climate, Population, Land Use, and Water Use}

The Ozark Plateaus study unit has a temperate climate with average annual precipitation ranging from about 38 inches per year (in/yr) in the north to about $48 \mathrm{in} / \mathrm{yr}$ near the southern edge of the study unit (Dugan and Peckenpaugh, 1985). Average monthly precipitation is greatest in the spring, about 3 to 5 inches per month (in/mo), and least in the late fall and winter, about 1 to $3 \mathrm{in} / \mathrm{mo}$. Mean annual air temperature ranges from about $56^{\circ} \mathrm{F}$ in the northeastern part of the study unit to about $60^{\circ} \mathrm{F}$ in the southwestern part of the study unit (Dugan and Peckenpaugh, 1985). Estimated mean annual evapotranspiration in the study unit is 30 to 35 in. (Hanson, 1991).

Population within the study unit in 1990 was approximately 2.3 million people (U.S. Department of Commerce, Bureau of Census, 1990). Population increased by about 28 percent between 1970 and 1990 with the largest increases occurring in northwestern Arkansas and southwestern Missouri. Springfield, Mo., with a population of about 140,000 residents (1990), is the largest city in the study unit. Joplin, Mo., and Fayetteville, Rogers, and Springdale, Ark., are the only other cities within the study unit with populations exceeding 20,000 (1990).

Land use in the study unit (table 1) is predominantly forest and agriculture (includes pasture and cropland) (U.S. Geological Survey, 1990). Deciduous

Table 1. Land-use percentage by physiographic area

[<, less than; 1978-83 land-use data from U.S. Geological Survey (1990)]

\begin{tabular}{|c|c|c|c|c|c|}
\hline \multirow{2}{*}{ Physiographic area } & \multicolumn{5}{|c|}{ Percent land use } \\
\hline & Urban & Agriculture $^{1}$ & Forest & Water & Barren $^{2}$ \\
\hline Osage Plains & 1 & 82 & 14 & 1 & 2 \\
\hline Springfield Plateau & 3 & 58 & 38 & 1 & $<1$ \\
\hline Salem Plateau & 1 & 27 & 71 & 1 & $<1$ \\
\hline Boston Mountains & 1 & 29 & 70 & $<1$ & $<1$ \\
\hline Mississippi Alluvial Plain & 1 & 83 & 8 & ${ }^{3} 8$ & $<1$ \\
\hline
\end{tabular}


forest is predominant in the Salem Plateau and Boston Mountains, although this is commonly mixed with evergreen forest. Some pasture also occurs in the Salem Plateau where livestock (beef and dairy cattle) are raised, mostly in the southern part. The Springfield Plateau is predominantly pasture, although this is mixed with cropland in the north and forest in the south. Intensive poultry farming occurs in pastures of the Springfield Plateau in northwestern Arkansas, southwestern Missouri, and northeastern Oklahoma. Cropland dominates in the Osage Plains and Mississippi Alluvial Plain. Major crops grown in the Osage Plains are soybeans and sorghum with some corn, wheat, grains, and field crops. Rice is the dominant crop grown in the Mississippi Alluvial Plain.

Total water use from both surface- and groundwater sources in the study unit was 1,053 million gallons per day (Mgal/d) in 1990 (Adamski and others, 1995). Of this, $614 \mathrm{Mgal} / \mathrm{d}$ was from ground-water sources and $439 \mathrm{Mgal} / \mathrm{d}$ was from surface-water sources. About 67 percent of the total ground-water use is for irrigation; however, most of this use is in counties along the extreme southeastern part of the study unit in the Mississippi Alluvial Plain. Domestic and public supply accounts for about 22 percent of the ground-water use. About 47 percent of the total surface-water use is for public supply and almost 30 percent is for commercial and industrial use. About 6 percent of the total water used in the study unit is for nonirrigation agricultural purposes.

\section{PESTICIDE USE}

Pesticide-use data are available for 24 pesticides and 20 crop types for the period 1982-85 (Gianessi and Puffer, 1988). Pesticide use (table 2) was estimated from county-level totals; for counties located along the study unit boundary, a correction factor was applied based on the percentage of the county within the study unit.

Approximately 4.2 million pounds per year of active ingredients from 24 pesticides were applied on 20 crop types within the study unit from 1982-85. Only 6 of the 24 pesticides were used extensively throughout the study unit and these account for approximately 88 percent of the total pesticides applied (table 2). Pesticide use generally was greatest in areas where the dominant land use was pastureland in the Springfield and Salem Plateaus and in cropland areas in the Osage Plains and Mississippi Alluvial Plain (fig. 2).

The most frequently applied pesticide in the study unit was 2,4-D (table 2, fig. 2). A selective herbicide, 2,4-D was most often applied to control weeds in pasture and cropland. Within the study unit, 2,4-D was applied most heavily in areas where pasture was the dominant crop type in the Springfield and Salem Plateaus. An estimated 912,583 pounds per year (lbs/ yr) of 2,4-D were applied in all 94 counties in the study unit. Usage per county varied from a minimum of $54 \mathrm{lbs} / \mathrm{yr}$ in Johnson County, Ark. to a maximum of 40,286 lbs/yr in Craig County, Okla.; the median usage was $8,085 \mathrm{lbs} / \mathrm{yr}$.

Alachlor, atrazine, propanil, trifluralin, and metolachlor were the other most frequently used pesticides in the study unit (table 2, fig. 2). All of these pesticides are herbicides used to control various weeds and grasses primarily in cropland areas. Usage for each of these pesticides ranges from $1 \mathrm{lb} / \mathrm{yr}$ to about 175,600 lbs/yr in individual counties, with median county application rates ranging from $834 \mathrm{lbs} /$ yr to $48,300 \mathrm{lbs} / \mathrm{yr}$. Propanil, a herbicide used on rice in a few counties in the extreme southeastern part of the study unit in the Mississippi Alluvial Plain, has the highest application rate per county.

To gain another perspective on pesticide use in the study unit, the total pesticide application rates by county (pounds per year) were converted to pounds per acre (within the entire county) per year. For counties located along the study unit boundary, a correction factor was applied based on the percentage of the county within the study unit. The Mississippi Alluvial Plain, located in the southeastern part of the study unit, had the highest application rate per acre (fig. 3). Application rates ranged from 0.1 to greater than 1.0 pounds per acre per year (lbs/acre/yr) in counties in this part of the study unit. The Osage Plains, in the northwestern part of the study unit, also had relatively high application rates, ranging from 0.05 to 1.0 lbs/acre/yr. The application rates in the Springfield and Salem Plateaus ranged from less than 0.01 to 1.0 $\mathrm{lbs} / \mathrm{acre} / \mathrm{yr}$. The application rates in the Boston and St. Francois Mountains ranged from less than 0.01 to $0.05 \mathrm{lbs} / \mathrm{acre} / \mathrm{yr}$.

Five crop types - corn, pasture, rice, sorghum, and soybeans-received approximately 90 percent of the pesticides applied within the study unit. Corn, sorghum, and soybeans were grown primarily in the Osage Plains; rice and soybeans were grown primarily 
Table 2. Estimated pesticide applications in the study unit, 1982-85, and description of pesticide type and use [Source: amount applied from Gianessi and Puffer (1988); description of use modified from Baldwin and others (1994), Becker and others (1992), Johnson and Jones (1994), Sine (1991), Spradley (1991; 1992)]

\begin{tabular}{|c|c|c|c|}
\hline \multirow[b]{2}{*}{ Pesticide } & \multirow{2}{*}{$\begin{array}{l}\text { Amount applied } \\
\text { (pounds per year of } \\
\text { active ingredient) }\end{array}$} & \multicolumn{2}{|r|}{ Pesticide } \\
\hline & & Type & Use \\
\hline $2,4-\mathrm{D}$ & 912,583 & Herbicide & Grasses, grains, pasture, and vegetables \\
\hline Alachlor & 739,730 & Herbicide & Vegetables, cotton, and nuts \\
\hline Atrazine & 565,808 & Herbicide & Corn and sorghum \\
\hline Propanil & 517,980 & Herbicide & Rice \\
\hline Trifluralin & 494,921 & Herbicide & Grains, vegetables, and nuts \\
\hline Metolachlor & 458,846 & Herbicide & Vegetables, nuts, and cotton \\
\hline Carbofuran & 129,228 & Insecticide, nematicide & Fruits, vegetables, grains, and cotton \\
\hline Cyanazine & 103,951 & Herbicide & Corn and fallow cropland \\
\hline Thiobencarb & 61,285 & Herbicide & Rice \\
\hline Carbaryl & 56,730 & Insecticide & Fruits, forests, and field crops \\
\hline Acifluorfen & 43,859 & Herbicide & Soybeans, peanuts, and rice \\
\hline Parathion & 32,522 & Insecticide & Fruits and alfalfa \\
\hline Methyl Parathion & 26,946 & Insecticide & Vegetables and alfalfa \\
\hline Malathion & 25,334 & Insecticide & Fruits and vegetables \\
\hline Disulfoton & 9,232 & Insecticide, acaricide & Grains and vegetables \\
\hline Phorate & 4,968 & Insecticide & Grains and grasses \\
\hline Vernolate & 3,572 & Herbicide & Turf \\
\hline Fluometuron & 2,883 & Herbicide & Cotton \\
\hline Enthoprop & 1,443 & Nematicide, insecticide & Fruits, vegetables, and grasses \\
\hline Metiram & 868 & Fungicide & Fruits, vegetables, and field crops \\
\hline PCNB & 716 & Fungicide, seed dressing & Vegetables, grains, and cotton \\
\hline Bensulide & 561 & Herbicide & Vegetables and lawns \\
\hline Chlorothalonil & 498 & Fungicide & Fruits and vegetables \\
\hline Diazinon & 408 & Insecticide, nematicide & Fruits, vegetables, field crops, and pasture \\
\hline TOTAL & $4,194,872$ & & \\
\hline
\end{tabular}



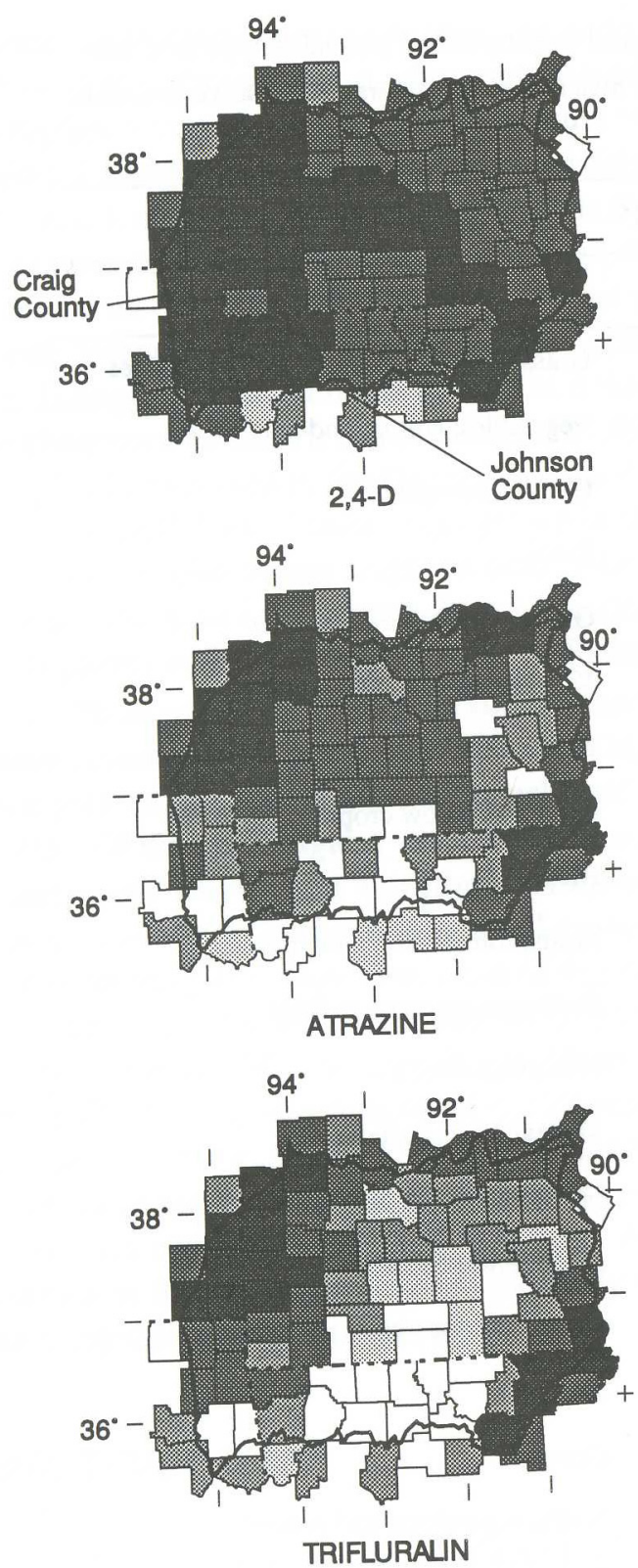

EXPLANATION

PESTICIDE USE, IN POUNDS PER YEAR

Less than 10

$10-100$

$100-1,000$

$1,000-10,000$

Greater than 10,000

— STUDY UNIT BOUNDARY

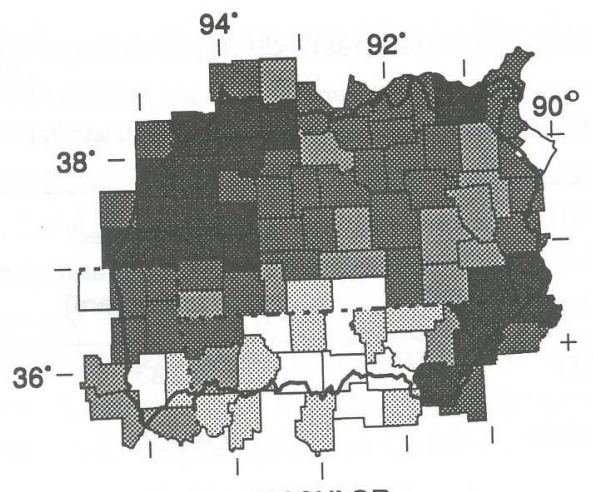

ALACHLOR
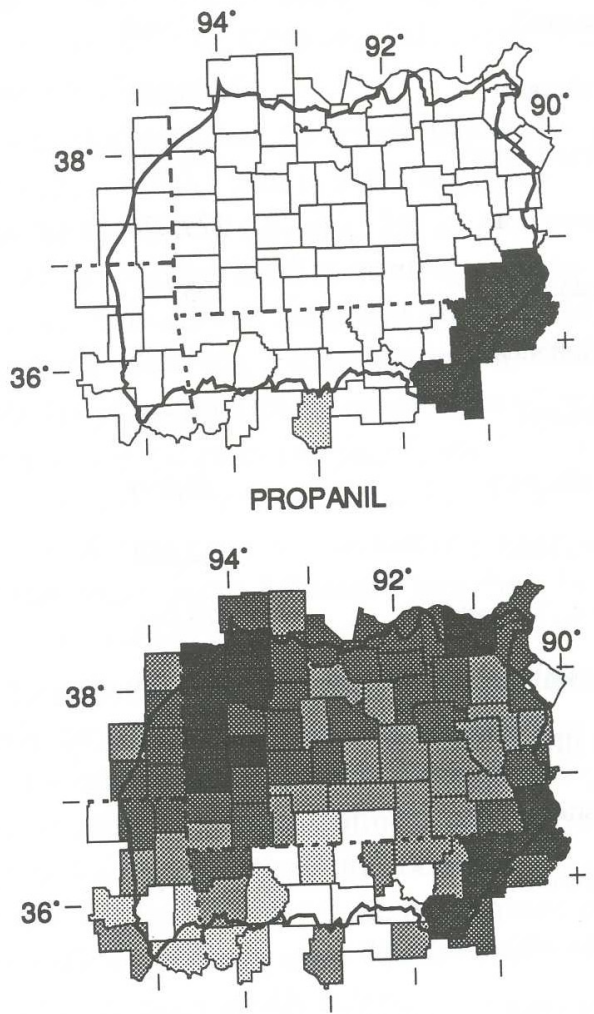

METOLACHLOR
O $50 \quad 100$ MILES

$0 \quad 50100$ KILOMETERS

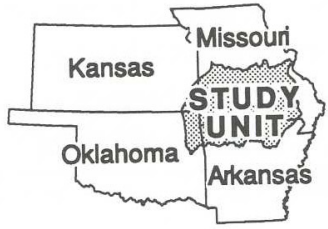




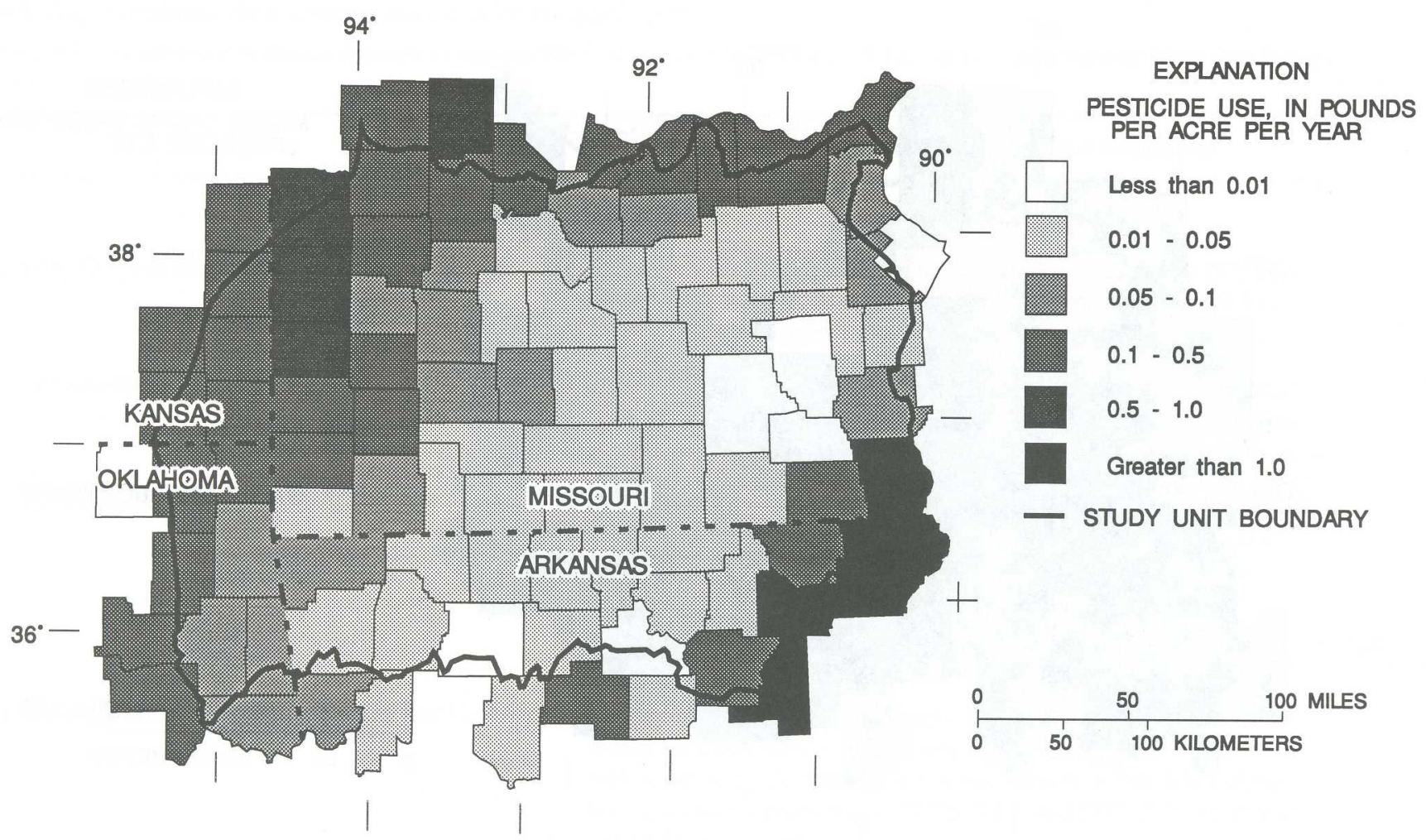

Figure 3. Pesticide application rate for counties within the study unit (calculated from data in Gianessi and Puffer, 1988).

in the Mississippi Alluvial Plain. Pastureland located in the Springfield and Salem Plateaus received moderate amounts of pesticides. Forestland and pastureland in the Boston and St. Francois Mountains received the least amounts of pesticides.

Pastureland was the predominate crop type in 50 of the 94 counties in the study unit based on crop estimates accompanying the pesticide-use data (fig.4). Pastureland dominated the Boston Mountains, St. Francois Mountains, and throughout most of the Springfield and Salem Plateaus. Corn, sorghum, and soybeans dominated the Osage Plains, and rice dominated the Mississippi Alluvial Plain.

\section{SOURCES OF WATER-QUALITY, BED- SEDIMENT, AND BIOLOGICAL-TISSUE DATA}

Pesticide-concentration data (the term "pesticide" hereinafter is used to refer to both pesticides and pesticide metabolites) and other water-quality data are collected by many Federal, State, and local govern- mental agencies for a variety of purposes. Industrial, wastewater, and water-supply facilities need waterquality information in order to make operational decisions. Regulatory agencies monitor water quality to determine compliance with permits and water-quality standards. Nonregulatory agencies monitor ambient water quality for the purposes of resource characterization and water-quality research. Depending on the purpose of data collection, samples may be collected employing various sample collection, processing, preservation, and analytical techniques and with various quality-assurance and quality-control requirements, resulting in different levels of detection and precision.

Numerous sources of pesticide data were available for the study unit, but only data collected by Federal or State governmental agencies and stored in computerized data bases were used in this report. Three Federal and three State agencies collected and maintained records of pesticide data for the majority of the surface-water, ground-water, bed-sediment, and biological-tissue sampling sites located within the study unit during the period of record (water year 


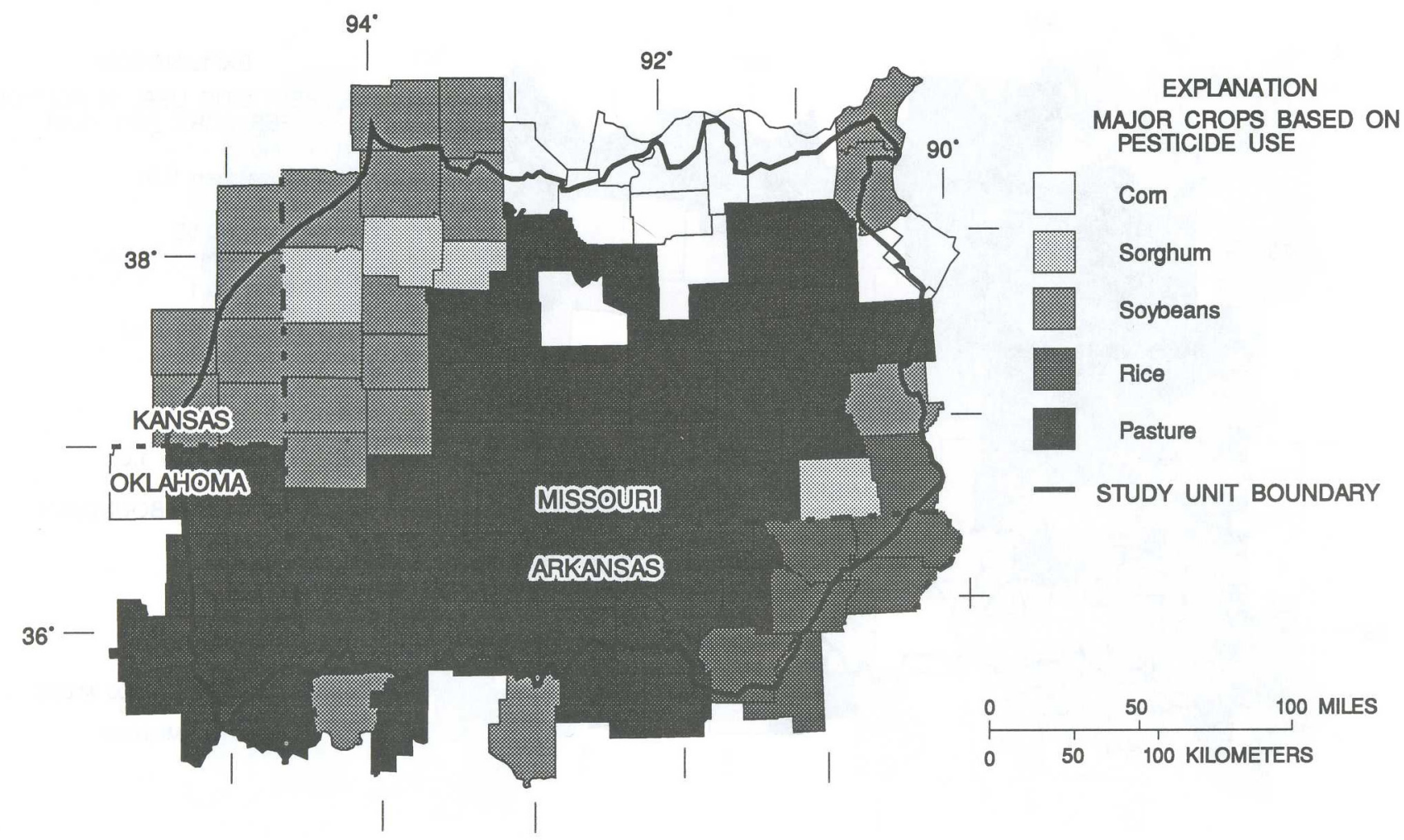

Figure 4. Crop types receiving the largest pesticide applications for counties within the study unit (calculated from data in Gianessi and Puffer, 1988).

1970-90) for this report (table 3). Each agency has different objectives for collecting pesticide data and these objectives affect the spatial, temporal, and hydrologic distribution of the data. No long-term pesticide monitoring networks were in operation in the study unit during the period of record.

Most of the computerized pesticide data available for the study unit resides in two national data bases: (1) USGS National Water Data Storage and Retrieval System (WATSTORE), and (2) U.S. Environmental Protection Agency's Storage and Retrieval system (STORET). WATSTORE was implemented in 1971 to provide processing, storage, and retrieval of water (and other media) data, and is capable of producing tables, graphs, and statistical analysis of these data (Hutchison, 1975). STORET is a data-management information system consisting of several software modules that allow the user to store and retrieve data, use analytical programs to access and analyze data, and pass data to user-written software or statistical packages (Hoelman, 1989).
The initial retrieval from WATSTORE and STORET located about 70,000 samples from 2,500 sample sites in the study unit for the period of record 1970-90. These 70,000 samples were searched for pesticide data, using more than 700 pesticide names.

About 2,200 samples from about 450 sample sites had pesticide data to which several additional screening techniques were applied: (1) for cases in which more than one agency collected samples at sites that are in close proximity to each other, these sites were combined to represent a single site; (2) for cases in which more than one sample was collected at a particular site on a single day, only data from the first sample of the day was used so as not to cause a bias in the statistical analysis; and (3) an individual pesticide with fewer than five samples was excluded from the final data set. The final data set for this report contains 1,623 samples from 407 sites (140 surface water, 92 ground water, 55 bed sediment, and 120 biological tissue). The number of pesticide sampling sites and samples 
Table 3. Major pesticide data sources available for the study unit

[STORET, U.S. Environmental Protection Agency's Storage and Retrieval system; WATSTORE, U.S. Geological Survey National Water Data Storage and Retrieval System]

\begin{tabular}{|c|c|}
\hline Agency & Data collection purpose, type, and accessibility \\
\hline \multicolumn{2}{|r|}{ Federal agencies } \\
\hline U.S. Army Corps of Engineers & $\begin{array}{l}\text { Resource assessment on Corps-developed projects; variety of water- } \\
\text { quality data, sometimes collected in cooperation with other Federal } \\
\text { agencies; data available from STORET and WATSTORE. }\end{array}$ \\
\hline U.S. Environmental Protection Agency & $\begin{array}{l}\text { Regulatory; wide variety of water-quality data, sometimes collected in } \\
\text { cooperation with State agencies; all data in STORET; information on } \\
\text { well construction and streamflow available. }\end{array}$ \\
\hline \multirow[t]{2}{*}{ U.S. Geological Survey } & $\begin{array}{l}\text { Water-resources assessment and research; limited monitoring network } \\
\text { for ground- and surface-water quality; all data are computerized in } \\
\text { WATSTORE including some State agency data; information on } \\
\text { streamflow and well construction available. }\end{array}$ \\
\hline & State agencies \\
\hline Arkansas Department of Pollution Control and Ecology & $\begin{array}{l}\text { Regulatory monitoring of } 110 \text { surface-water sites statewide, } 46 \text { sites } \\
\text { within the study unit; samples analyzed for inorganic constituents, } \\
\text { with some pesticide data and fish-tissue analysis for metals and organ- } \\
\text { ics; data are computerized in WATSTORE and STORET; information } \\
\text { available on streamflow. }\end{array}$ \\
\hline Kansas Department of Health and Environment & $\begin{array}{l}\text { Monitoring network of surface- and ground-water quality originally in } \\
\text { cooperation with the U.S. Geological Survey, but independently since } \\
\text { 1990; } 20 \text { years of records, virtually all data in STORET; chemical and } \\
\text { biological analyses for approximately } 240 \text { surface-water sites state- } \\
\text { wide, } 15 \text { sites within the study unit; about } 30-40 \text { percent have stream- } \\
\text { flow data. }\end{array}$ \\
\hline Oklahoma Department of Environmental Quality & $\begin{array}{l}\text { Monitoring ambient water quality and assessment of hazardous waste } \\
\text { sites; most data in STORET or other computerized data base; some fish- } \\
\text { tissue and bed-sediment data available, some pesticide data available; } \\
\text { some streamflow information available. }\end{array}$ \\
\hline
\end{tabular}

collected for each sample type, by agency, is summarized in table 4.

\section{SPATIAL AND TEMPORAL DISTRIBUTION OF PESTICIDE DATA}

The spatial and temporal distribution of pesticide data is an important factor when evaluating the significance of that data. Spatial and temporal distribution, site and basin characteristics, land use, and ground-water site type and well depth are all important factors when assessing the representativeness and suitability of data for statistical analysis.

\section{Surface Water}

Pesticide data are available for 1,002 samples from 140 surface-water sampling sites within the study unit (fig. 5; table 5, at the back of this report). Spatial distribution of the surface-water sampling sites is not uniform. The density of sampling sites is greatest in the Springfield Plateau and Osage Plains and least for the St. Francois Mountains and western part of the Salem Plateau. Most surface-water sampling sites have drainage basins in the Springfield (45 sites) and Salem (43 sites) Plateaus; fewer have drainage basins in the Osage Plains (18 sites), and Boston Mountains (3 sites). Thirty-one surface-water sites 
Table 4. Summary of number of pesticide sampling sites and samples collected for each sample type, by agency

\begin{tabular}{|c|c|c|c|c|c|c|c|c|}
\hline \multirow[b]{2}{*}{ Agency } & \multicolumn{2}{|c|}{ Surface water } & \multicolumn{2}{|c|}{ Ground water } & \multicolumn{2}{|c|}{ Bed sediment } & \multicolumn{2}{|c|}{ Biological tissue } \\
\hline & $\begin{array}{l}\text { Number } \\
\text { of } \\
\text { sampling } \\
\text { sites }\end{array}$ & $\begin{array}{c}\text { Number } \\
\text { of } \\
\text { samples }\end{array}$ & $\begin{array}{l}\text { Number } \\
\text { of } \\
\text { sampling } \\
\text { sites }\end{array}$ & $\begin{array}{l}\text { Number } \\
\text { of } \\
\text { samples }\end{array}$ & $\begin{array}{l}\text { Number } \\
\text { of } \\
\text { sampling } \\
\text { sites }\end{array}$ & $\begin{array}{l}\text { Number } \\
\text { of } \\
\text { samples }\end{array}$ & $\begin{array}{l}\text { Number } \\
\text { of } \\
\text { sampling } \\
\text { sites }\end{array}$ & $\begin{array}{c}\text { Number } \\
\text { of } \\
\text { samples }\end{array}$ \\
\hline $\begin{array}{l}\text { U.S. Army Corps of } \\
\text { Engineers }\end{array}$ & 1 & 2 & - & - & - & - & 1 & 1 \\
\hline $\begin{array}{l}\text { U.S. Environmental } \\
\text { Protection Agency }\end{array}$ & 39 & 70 & - & - & 31 & 31 & 78 & 179 \\
\hline U.S. Geological Survey & 30 & 158 & 92 & 103 & 6 & 21 & - & - \\
\hline $\begin{array}{l}\text { Arkansas Department of } \\
\text { Pollution Control and } \\
\text { Ecology }\end{array}$ & 46 & 582 & - & - & 8 & 11 & 22 & 71 \\
\hline $\begin{array}{l}\text { Kansas Department of } \\
\text { Health and Environment }\end{array}$ & 17 & 168 & - & - & - & - & 15 & 143 \\
\hline $\begin{array}{l}\text { Oklahoma Department } \\
\text { of Environmental Quality }\end{array}$ & 8 & 22 & - & - & 10 & 24 & 4 & 37 \\
\hline TOTAL & ${ }^{1} 140$ & 1,002 & 92 & 103 & 55 & 87 & 120 & 431 \\
\hline
\end{tabular}

have drainage basins that cover parts of two or more physiographic areas. All or part of the drainage basins for 8 of the 11 sites where 20 or more samples were collected are located in the Springfield Plateau.

Many sites were sampled only once (42 sites) or twice (19 sites) during the period of record. The sites with the most samples collected are the White River near Norfork, Ark. (site 33, 39 samples) and the Neosho River at Chetopa, Kans. (site 82, 33 samples). About 50 percent of the 1,002 samples were collected in the mid-1970's and early-1980's. The 5 years in which the largest number of samples were collected are 1982 (124 samples), 1981 (117 samples), 1974 (97 samples), 1975 (83 samples), and 1973 (82 samples). Samples were collected in 16 or more years at the Spring River near Waco, Mo. (site 106, 17 years) and the Neosho River at Chetopa, Kans. (site 82, 16 years). The White River near Norfork, Ark. (site 33) had the most consecutive years (water years 1981-87) in which three or more samples were collected.

\section{Ground Water}

Pesticide data are available for 103 samples from 92 ground-water sampling sites (90 wells; 2 springs) within the study unit (fig. 6; table 6, at the back of this report). Spatial distribution of the groundwater sampling sites is not uniform. The density of sampling sites is greatest in the Osage Plains and Mississippi Alluvial Plain and least in the St. Francois Mountains, Boston Mountains, the Salem Plateau, and the Springfield Plateau. Ninety-four percent of the sites are located in the northwestern or southeastern parts of the study unit. A pesticide-occurrence survey conducted by Ziegler and others (1994) in the northwestern part of the study unit during 1990-91 accounts for 66 percent of the sites. Nearly 70 percent of the samples were collected from the Western Interior Plains confining system (64 sites); about 21 percent of the samples were collected from the Mississippi River Valley alluvial aquifer (13 sites). Only four sites obtaining water from the Springfield Plateau aquifer and only three sites obtaining water from 


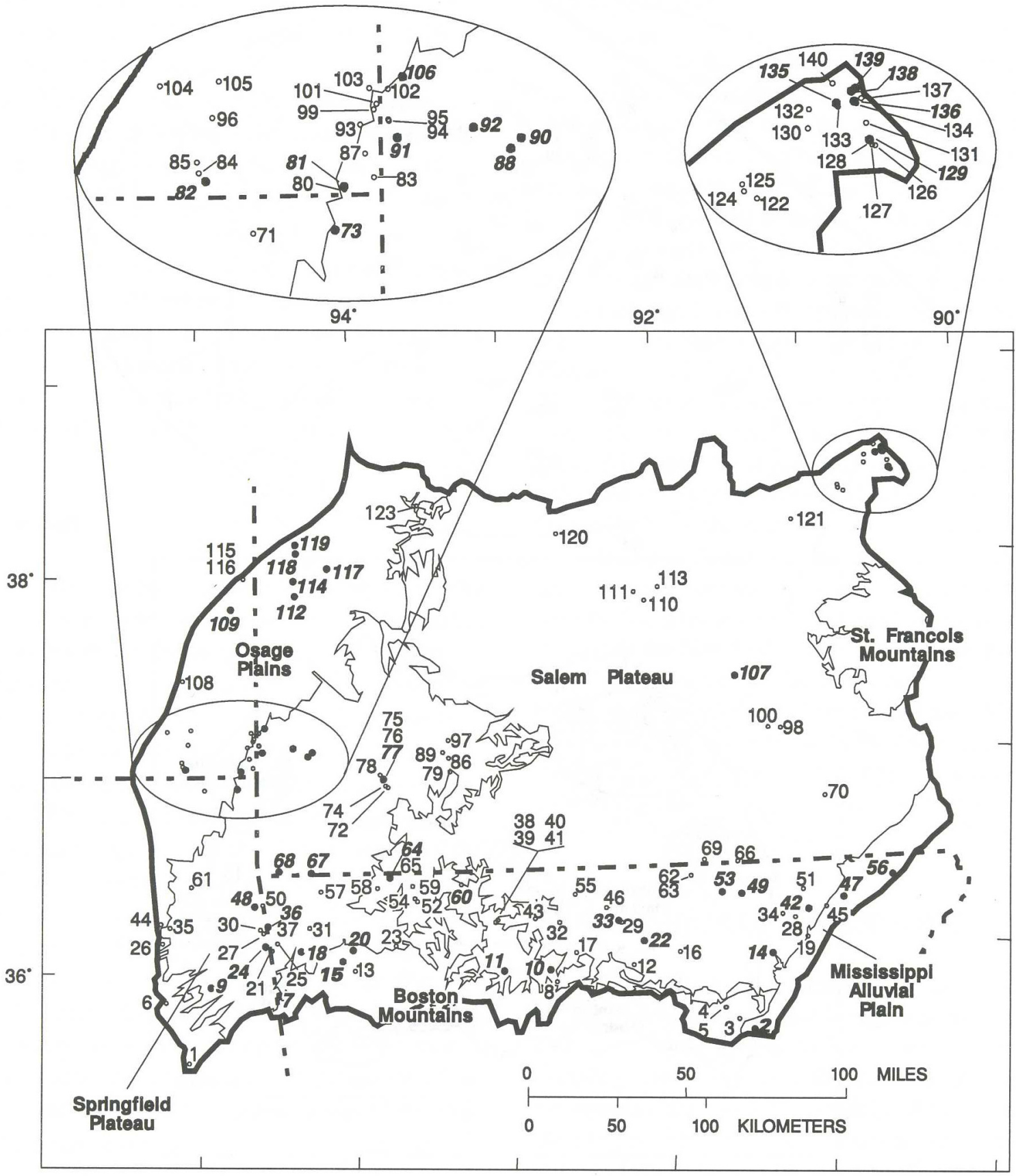

\section{EXPLANATION}

PHYSIOGRAPHIC AREA 120 。 SURFACE-WATER PESTICIDE BOUNDARY SAMPLING SITE--Number refers to site number in table 5

STUDY-UNIT BOUNDARY 139 SURFACE-WATER PESTICIDE SAMPLING SITE WHERE AT LEAST ONE PESTICIDE WAS DETECTED--

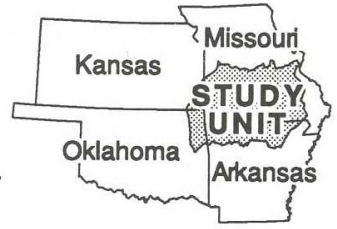




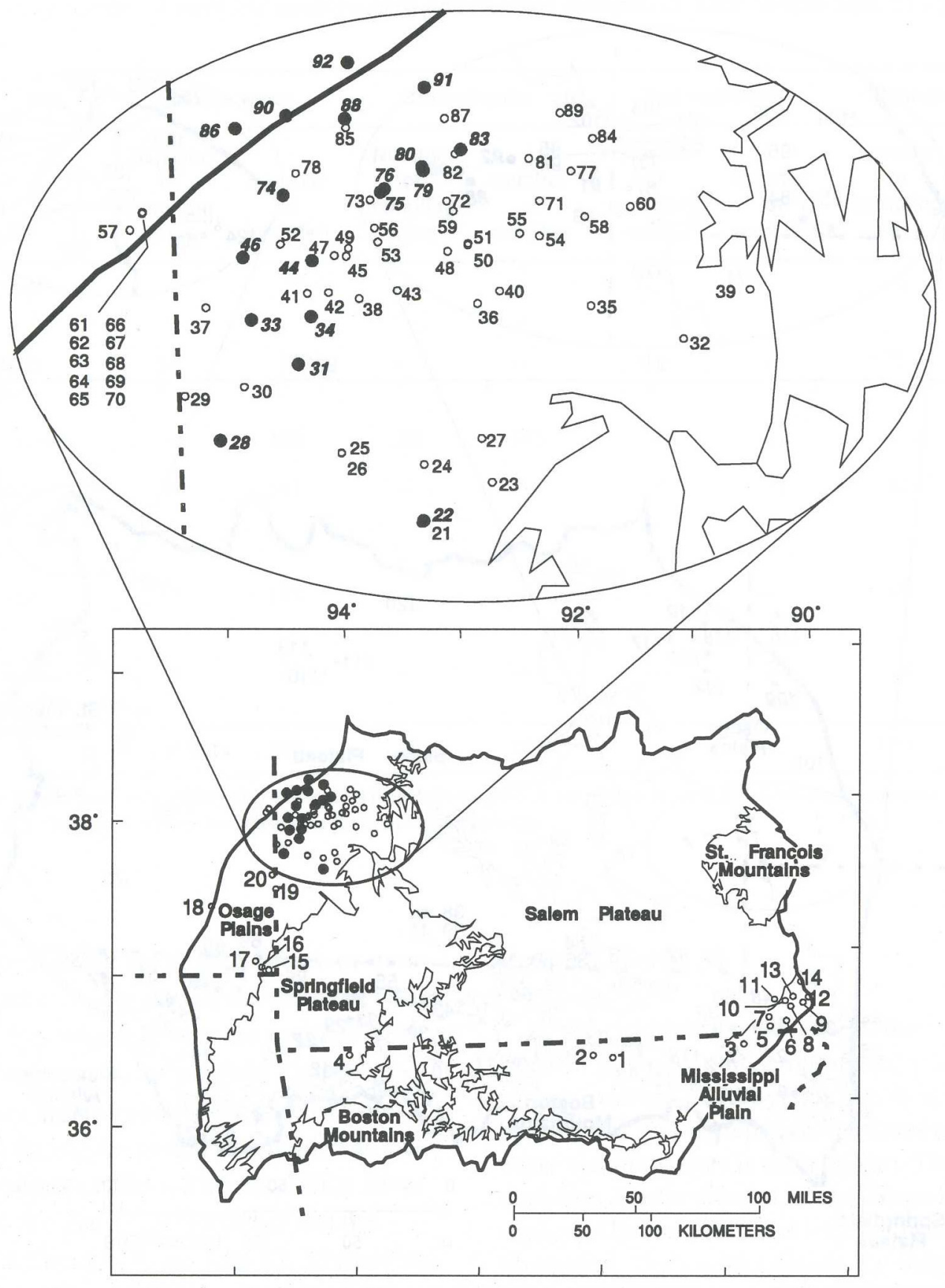

PHYSIOGRAPHIC AREA $1 \circ$ GROUND-WATER PESTICIDE BOUNDARY

_ STUDY-UNIT BOUNDARY

- - - STATE BOUNDARY
EXPLANATION SAMPLING SITE--Number refers to site number in table 6

22 - GROUND-WATER PESTTCIDE SAMPLING SITE WHERE AT LEAST ONE PESTICIDE WAS DETECTED--

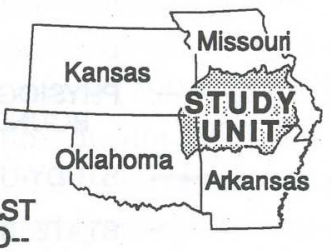

Number refers to site number in table 6 
the Ozark aquifer were sampled. Depths of the wells included in the data set ranges from 8 to $1,769 \mathrm{ft}$. Most of the wells (84) are less than $320 \mathrm{ft}$ deep. Sixty-two of the 92 wells are private wells used for domestic purposes. Uses for the other wells include public supply, stock, and irrigation.

Most ground-water sites were sampled only once ( 85 sites) or twice ( 3 sites) during the period of record. Four sites (sites 6,7,13, and 14) were sampled three times. Sixty percent of the samples were collected in 1990 in a study by Ziegler and others (1994). The years with the largest number of samples collected were 1990 (62 samples), 1989 (11 samples), 1987 (10 samples), and 1986 (8 samples).

\section{Bed Sediment}

Pesticide data are available for 87 samples from 55 bed-sediment sampling sites, which were located in streams within the study unit (fig. 7; table 7, at the back of this report). Spatial distribution of the bedsediment sampling sites is not uniform. The density of sampling sites is greatest in the northeastern Salem Plateau and the central and southwestern parts of the Springfield Plateau, and least in the St. Francois

Mountains and large areas of the Osage Plains and the Salem Plateau. Most bed-sediment sites are located in the southern and extreme northeastern Salem Plateau (16 sites), and the Springfield Plateau (14 sites). Substantially fewer sites are located in the Osage Plains (2 sites) and Boston Mountains (1 site). Twenty-two sites have drainage basins that cover parts of two or more physiographic areas. Six or more samples were collected at three sites located in the Springfield Plateau.

Most bed-sediment sites were sampled only once (42 sites) or twice ( 8 sites) during the period of record. Most sites at which more than one sample was collected are located in the southern part of the study unit. The sites with the greatest number of samples are North Sylamore Creek near Fifty Six, Ark. (site 3, 9 samples), the Illinois River at Highway 64 Bridge, Okla. (site 7, 7 samples), and the Illinois River near Tahlequah, Okla. (site 6, 6 samples). About 40 percent of the 87 samples were collected during the late 1980 's. The years in which the largest number of samples were collected were: 1990 (16 samples), 1981 (12 samples), and 1988 (11 samples).

\section{Biological Tissue}

Pesticide data are available for 431 biologicaltissue (fish and shellfish) samples from 120 sampling sites within the study unit (fig. 8 ; table 8 , at the back of this report). Spatial distribution of the biologicaltissue sampling sites is not uniform; the density of sampling sites is greatest in the Springfield Plateau and Osage Plains and least in the St. Francois Mountains and the central and western parts of the Salem Plateau. Most biological-tissue sampling sites drain basins wholly in the Salem Plateau (47 sites) and Springfield Plateau (35 sites). Fewer sites are located in the Osage Plains (17 sites). Twenty-one sites have drainage basins that cover parts of two or more physiographic areas. All 7 sites from which 17 or more samples were collected are located in the Springfield Plateau or Osage Plains in the western part of the study unit.

Many biological-tissue sites were sampled only once (51 sites) or twice ( 20 sites) during the period of record. The sites at which the most samples were collected are the Neosho River near Chetopa, Kans. (site 47, 32 samples) and Spring River near Waco, Mo. (site 69, 26 samples). About 50 percent of the 431 samples were collected between 1981-86. The 5 years in which the largest number of samples were collected were: 1983 (68 samples), 1984 (34 samples), 1981 (33 samples), 1986 (32 samples), and 1973 (30 samples).

\section{ASSESSMENT OF CONDITIONS}

Water quality is affected by factors related to physiography, geology, and land use and other human activities. Because of the limited spatial distribution of sampling sites and gaps in the temporal distribution of the samples, the available pesticide data are insufficient to provide a rigorous statistical analysis of the effects of these factors on water quality in the study unit. The following sections provide a descriptive statistical summary of recent historical pesticide data for surface water, ground water, bed sediment, and biological tissue.

Limitations in laboratory analytical techniques and equipment determine the lower limit below which constituent concentrations cannot be accurately determined. When the actual concentration is less than this lower limit, the concentration is reported as less than the detection limit of the analytical method. A particular constituent may have concentrations with several 


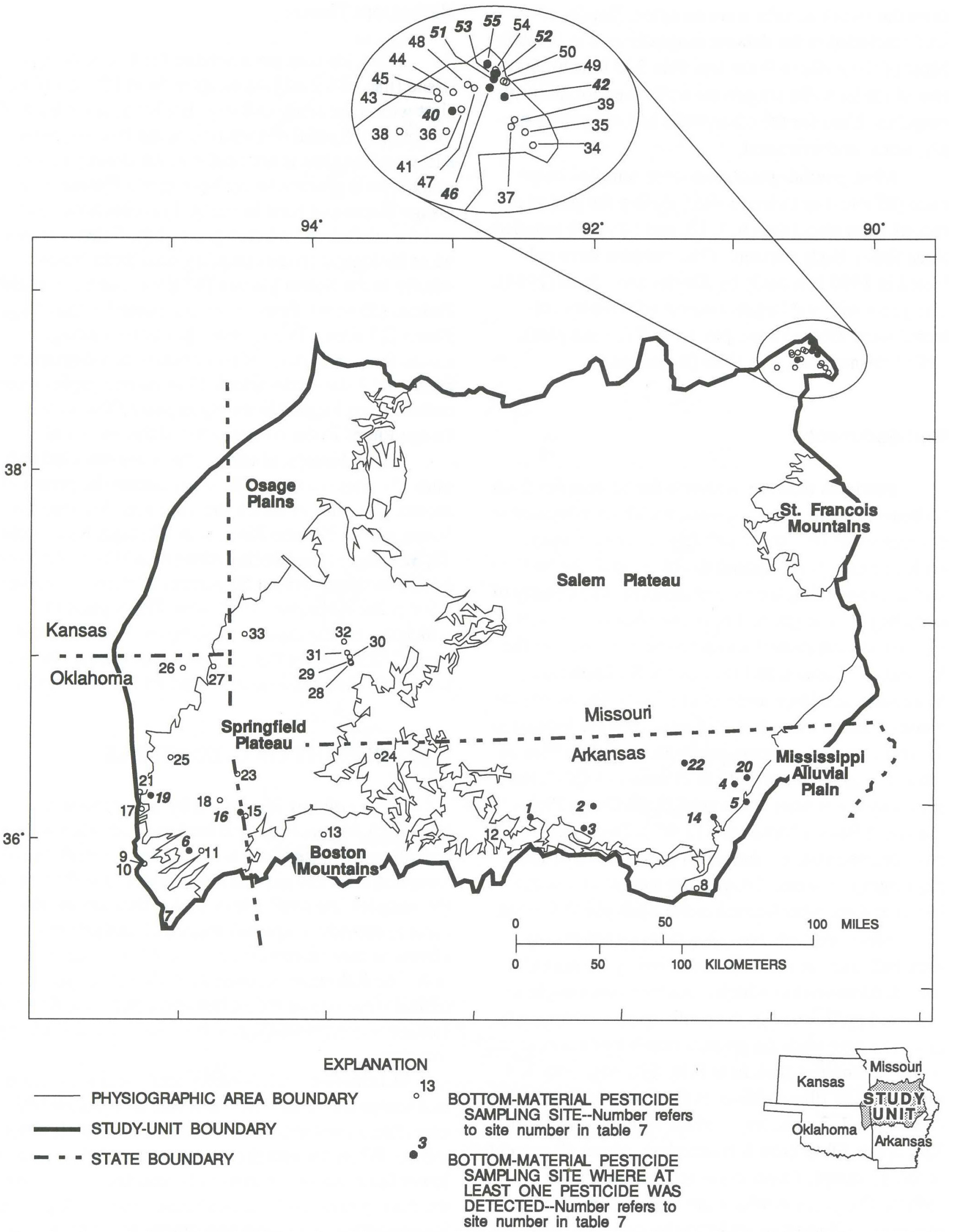




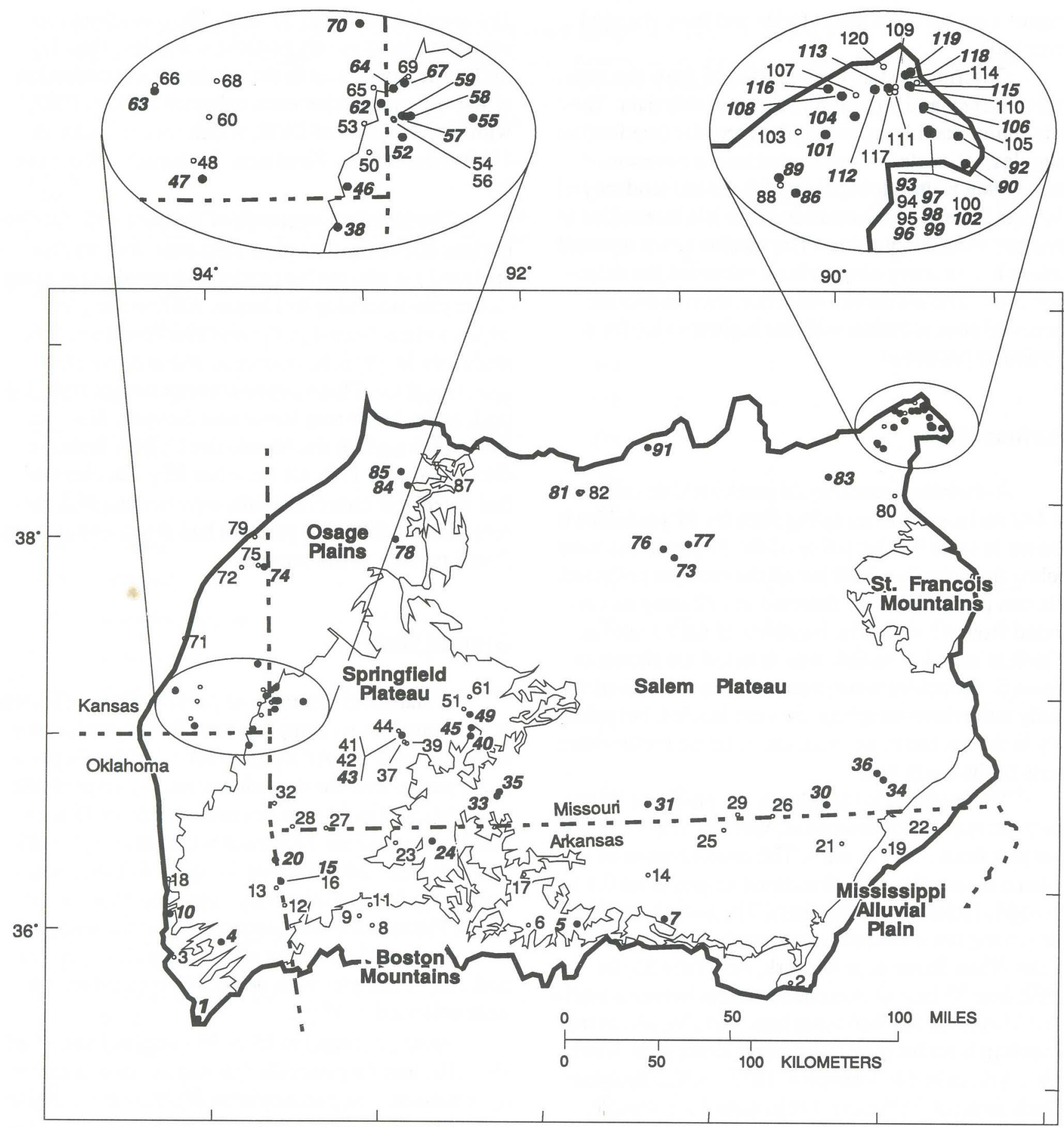

EXPLANATION

PHYSIOGRAPHIC AREA BOUNDARY

STUDY-UNIT BOUNDARY

- - $\quad$ STATE BOUNDARY
.14 BIOLOGICAL-TISSUE PESTICIDE SAMPLING SITE--Number refers to site number in table 8

7 BIOLOGICAL-TISSUE PESTICIDE SAMPLING SITE WHERE AT LEAST ONE PESTICIDE WAS DETECTED-Number refers to site number in table 8

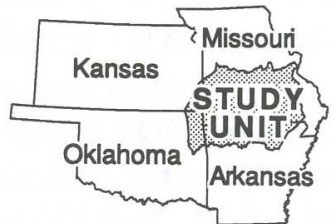


different detection limits because analytical techniques vary between laboratories and have changed over time.

Descriptive statistics are used to show the central tendency and variation in the pesticide data. The minimum, maximum, and 50th percentile (median) of samples with detected concentrations are presented; the median is used to represent the central tendency of the data instead of the mean because it is insensitive to extreme values in the data. The median is not reported unless five or more observations exceeded the detection limit. The maximum detection limit shows the censored concentration with the highest value for a particular parameter.

\section{Surface Water}

A statistical summary of pesticide data collected at 140 surface-water sampling sites for 51 pesticides is shown in table 9. Thirty-five of the 51 pesticides were below the detection limit for all the samples collected. Sixteen pesticides were detected in 132 samples collected from 43 sites. The locations of the 43 sites at which at least 1 pesticide was detected are shown in figure 5. Pesticides were detected in most areas of the study unit where sampling sites are located, but primarily in the southern, western, and extreme northeastern parts of the study unit.

The insecticide toxaphene, the pesticide having the most number of detections, was found in 17 of 866 samples from 5 of 112 sites. The concentration of toxaphene in samples with detections ranged from 0.1 to $6.0 \mu \mathrm{g} / \mathrm{L}$ (micrograms per liter). The toxaphene sample having the maximum concentration was collected at the White River near Norfork, Ark. (site 33) in 1982. Site 33 had 12 toxaphene detects between 198185. Other sites that had toxaphene samples above the detection limit include: Strawberry River near Smithville, Ark. (site 14; 2 samples, 1975, 1982); Spavinaw Creek north of Sycamore, Okla. (site 36; 1 sample, 1975); Spavinaw Creek near Sycamore, Okla. (site 48; 1 sample, 1975); South Fork Spring River at Saddle, Ark. (site 53; 1 sample, 1985).

Six other pesticides were detected in 12 or more samples: DDE was detected in 16 of 718 samples from 15 sites of 75 sites; dieldrin was detected in 15 of 990 samples from 15 of 132 sites; DDT was detected in 15 of 794 samples from 14 of 88 sites; aldrin was detected in 14 of 977 samples from 13 of 122 sites; 2,4-D was detected in 13 of 514 samples from 9 of 76 sites; lindane (parameter code 39340) was detected in 12 of 194 samples from 6 of 59 sites. The maximum concentration for these six pesticides was less than $1.0 \mu \mathrm{g} / \mathrm{L}$. The samples with the maximum concentration of these six pesticides were collected prior to 1983, with the exception of DDE, which was collected in 1990 at the Illinois River near Tahlequah, Okla. (site 9).

The highest percentage of samples with concentrations above the detection limit were for samples analyzed for triazine herbicides and metabolites using an enzyme screening technique. All five samples, which were collected in the northwestern part of the study unit in 1990, had concentrations above the detection limit. These concentrations ranged from 1.0 $\mu \mathrm{g} / \mathrm{L}$ at the Marmaton River near Nevada, Mo. (site 112) to $5.0 \mu \mathrm{g} / \mathrm{L}$ at the Marais des Cygnes drainage ditch, Mo. (site 118). Of the other 15 pesticides that had detectable concentrations, only lindane (6.2 percent) and alachlor (5.2 percent) had detections in more than 4 percent of the samples.

\section{Ground Water}

A statistical summary of pesticide data collected at 92 ground-water sampling sites for 44 pesticides is shown in table 10. All samples for 37 of the 44 pesticides were below the detection limit. Seven pesticides were detected in 31 samples collected from 18 sites. The locations of the 18 sites at which at least 1 pesticide was detected are shown in figure 6 . These pesticides were found exclusively in ground water in the Osage Plains in the northwestern part of the study unit; however, spatial coverage of sampling sites was limited. All 31 samples with detectable concentrations were collected in 1990.

Atrazine, found in 15 of 95 samples from 15 of 79 wells, was the pesticide that had the most number of detections. The concentration of atrazine in samples with detections ranged from 0.1 to $8.2 \mu \mathrm{g} / \mathrm{L}$. The atrazine sample having the maximum concentration was collected at site 88 . Fourteen other sites in the northwestern part of the study unit had samples with atrazine concentrations above the detection limit: sites 22, 28, 31, 33, 34, 44, 46, 74, 79, 80, 83, 90, 91, 92.

Three other pesticides were detected more than once: metolachlor was detected in 5 of 93 samples from 5 of 73 wells; alachlor was detected in 5 of 96 samples from 5 of 76 wells; prometon was detected in 3 of 15 samples from 3 of 15 wells. The maximum 
Table 9. Statistical summary of pesticide data from surface-water sampling sites for water years 1970-90

[STORET parameter code, U.S. Environmental Protection Agency's Storage and Retrieval code assigned to a parameter based on factors including the medium type and the analytical method used for the analysis; $\mu \mathrm{g} / \mathrm{L}$, micrograms per liter; --, data unavailable; ww, whole water]

\begin{tabular}{|c|c|c|c|c|c|c|c|c|c|}
\hline \multirow[b]{2}{*}{$\begin{array}{c}\text { STORET } \\
\text { para- } \\
\text { meter } \\
\text { code }\end{array}$} & \multirow[b]{2}{*}{ Parameter name } & \multicolumn{3}{|c|}{$\begin{array}{l}\text { Detected concentration } \\
\qquad(\mu \mathrm{g} / \mathrm{L})\end{array}$} & \multicolumn{4}{|c|}{ Number of } & \multirow[b]{2}{*}{ 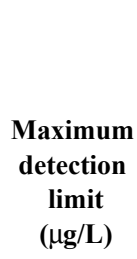 } \\
\hline & & $\begin{array}{l}\text { Mini- } \\
\text { mum }\end{array}$ & Median & $\begin{array}{l}\text { Maxi- } \\
\text { mum }\end{array}$ & samples & sites & $\begin{array}{c}\text { sites with } \\
\text { a detectable } \\
\text { concentration }\end{array}$ & $\begin{array}{l}\text { samples with } \\
\text { a detectable } \\
\text { concentration }\end{array}$ & \\
\hline 34541 & 1,2-dichloropropane, total & -- & -- & -- & 54 & 26 & 0 & 0 & 10. \\
\hline 39730 & $2,4-\mathrm{D}$, total & 0.02 & 0.03 & 0.61 & 514 & 76 & 9 & 13 & 0.8 \\
\hline 34601 & 2,4-dichlorophenol, total & -- & -- & -- & 55 & 27 & 0 & 0 & 52. \\
\hline 39360 & DDD, total & -- & -- & 0.01 & 312 & 54 & 1 & 1 & 1.0 \\
\hline 39365 & DDE, total & 0.001 & 0.001 & 0.01 & 718 & 75 & 15 & 16 & 1.0 \\
\hline 39370 & DDT, total & 0.001 & 0.002 & 0.023 & 794 & 88 & 14 & 15 & 10. \\
\hline 39305 & o,p'-DDT, total & -- & -- & -- & 90 & 11 & 0 & 0 & 10. \\
\hline 39300 & p,p'-DDT, total & -- & -- & -- & 169 & 48 & 0 & 0 & 1.1 \\
\hline 39040 & DEF, total & -- & -- & -- & 17 & 2 & 0 & 0 & 0.01 \\
\hline 39250 & PCN, total & -- & -- & -- & 59 & 16 & 0 & 0 & 5.0 \\
\hline 34200 & Acenaphthylene, total & -- & -- & -- & 55 & 27 & 0 & 0 & 10. \\
\hline 77825 & Alachlor, total recoverable & 0.015 & 0.66 & 4.2 & 115 & 23 & 5 & 6 & 0.5 \\
\hline 39330 & Aldrin, total & 0.001 & 0.001 & 0.001 & 977 & 122 & 13 & 14 & 1.0 \\
\hline 39337 & Alpha benzene hexachloride, total & 0.02 & -- & 0.02 & 93 & 44 & 3 & 3 & 0.19 \\
\hline 39338 & $\begin{array}{l}\text { Beta benzene hexachloride, } \\
\text { total }\end{array}$ & -- & -- & -- & 72 & 30 & 0 & 0 & 0.38 \\
\hline 39062 & $\begin{array}{l}\text { Chlordane, cis isomer, ww, } \\
\text { total }\end{array}$ & -- & -- & -- & 10 & 3 & 0 & 0 & 0.1 \\
\hline 39350 & Chlordane, total & 0.2 & 0.3 & 0.5 & 353 & 76 & 3 & 7 & 3.8 \\
\hline 39065 & Chlordane, trans isomer, ww, total & -- & -- & -- & 10 & 3 & 0 & 0 & 0.1 \\
\hline 39071 & $\begin{array}{l}\text { Chlordane-nonachlor, trans } \\
\text { isomer, ww, total }\end{array}$ & -- & -- & -- & 10 & 3 & 0 & 0 & 0.1 \\
\hline 81403 & Chloropyrifos, total & -- & -- & -- & 62 & 28 & 0 & 0 & 10. \\
\hline 34704 & Cis-1,3-dichloropropene, total & -- & -- & -- & 51 & 23 & 0 & 0 & 1.0 \\
\hline 34699 & Trans-1,3-dichloropropene, total & -- & -- & -- & 52 & 24 & 0 & 0 & 1.0 \\
\hline 39570 & Diazinon, total & -- & -- & 0.01 & 60 & 14 & 1 & 1 & 0.1 \\
\hline 39380 & Dieldrin, total & 0.001 & 0.001 & 0.01 & 990 & 132 & 15 & 15 & 2.0 \\
\hline 39011 & Disyston, total & -- & -- & -- & 17 & 2 & 0 & 0 & 0.01 \\
\hline 39388 & Endosulfan I, total & -- & -- & -- & 188 & 50 & 0 & 0 & 1.0 \\
\hline 34361 & Endosulfan I, ww, recoverable & -- & -- & -- & 70 & 29 & 0 & 0 & 0.38 \\
\hline 34356 & Endosulfan beta, total & -- & -- & -- & 70 & 29 & 0 & 0 & 0.63 \\
\hline 34351 & Endosulfan sulfate, total & -- & -- & -- & 70 & 29 & 0 & 0 & 1.3 \\
\hline
\end{tabular}


Table 9. Statistical summary of pesticide data from surface-water sampling sites for water years 1970-90--Continued

[STORET parameter code, U.S. Environmental Protection Agency's Storage and Retrieval code assigned to a parameter based on factors including the medium type and the analytical method used for the analysis; $\mu \mathrm{g} / \mathrm{L}$, micrograms per liter; --, data unavailable; ww, whole water]

\begin{tabular}{|c|c|c|c|c|c|c|c|c|c|}
\hline \multirow{2}{*}{$\begin{array}{c}\text { STORET } \\
\text { para- } \\
\text { meter } \\
\text { code }\end{array}$} & \multirow[b]{2}{*}{ Parameter name } & \multicolumn{3}{|c|}{$\begin{array}{l}\text { Detected concentration } \\
(\mu \mathrm{g} / \mathbf{L})\end{array}$} & \multicolumn{4}{|c|}{ Number of } & \multirow{2}{*}{$\begin{array}{c}\text { Maximum } \\
\text { detection } \\
\text { limit } \\
(\mu \mathrm{g} / \mathrm{L})\end{array}$} \\
\hline & & $\begin{array}{l}\text { Mini- } \\
\text { mum }\end{array}$ & Median & $\begin{array}{l}\text { Maxi- } \\
\text { mum }\end{array}$ & samples & sites & $\begin{array}{c}\text { sites with } \\
\text { a detectable } \\
\text { concentration }\end{array}$ & $\begin{array}{l}\text { samples with } \\
\text { a detectable } \\
\text { concentration }\end{array}$ & \\
\hline 39398 & Ethion, total & -- & -- & -- & 46 & 10 & 0 & 0 & 0.01 \\
\hline 39421 & Heptachlor epoxide, dissolved & -- & -- & -- & 7 & 7 & 0 & 0 & 1.0 \\
\hline 39420 & Heptachlor epoxide, total & -- & -- & -- & 438 & 97 & 0 & 0 & 1.0 \\
\hline 39410 & Heptachlor, total & 0.014 & -- & 0.23 & 439 & 97 & 1 & 3 & 1.0 \\
\hline 39700 & Hexachlorobenzene, total & -- & -- & -- & 71 & 32 & 0 & 0 & 10. \\
\hline 39340 & Lindane, total & 0.012 & 0.052 & 0.29 & 194 & 59 & 6 & 12 & 0.2 \\
\hline 39782 & Lindane, total & 0.03 & -- & 0.07 & 810 & 81 & 1 & 3 & 10. \\
\hline 39530 & Malathion, total & -- & -- & -- & 235 & 60 & 0 & 0 & 1.0 \\
\hline 39480 & Methoxychlor, total & -- & -- & -- & 365 & 69 & 0 & 0 & 50. \\
\hline 39600 & Methyl parathion, total & -- & -- & -- & 510 & 59 & 0 & 0 & 7.0 \\
\hline 39356 & Metolachlor, ww & -- & -- & -- & 80 & 17 & 0 & 0 & 0.25 \\
\hline 81408 & Metribuzin, ww & -- & -- & 0.57 & 101 & 17 & 1 & 1 & 0.1 \\
\hline 39755 & Mirex, total & -- & -- & -- & 60 & 14 & 0 & 0 & 0.01 \\
\hline 39540 & Parathion, total & -- & -- & -- & 51 & 11 & 0 & 0 & 0.01 \\
\hline 39034 & Perthane, total & -- & -- & -- & 34 & 10 & 0 & 0 & 0.1 \\
\hline 39023 & Phorate, total & -- & -- & -- & 17 & 2 & 0 & 0 & 0.01 \\
\hline 39760 & Silvex, total & -- & -- & -- & 99 & 17 & 0 & 0 & 0.01 \\
\hline 39055 & Simazine, total & -- & -- & -- & 843 & 100 & 0 & 0 & 0.5 \\
\hline 39402 & Toxaphene, suspended, total & -- & -- & -- & 20 & 14 & 0 & 0 & 2.5 \\
\hline 39400 & Toxaphene, total & 0.1 & 0.7 & 6.0 & 866 & 112 & 5 & 17 & 7.0 \\
\hline 34757 & $\begin{array}{l}\text { Triazine screen by enzyme } \\
\text { ww, recoverable }\end{array}$ & 1.0 & 4.0 & 5.0 & 5 & 5 & 5 & 5 & -- \\
\hline 39786 & Trithion, total & -- & -- & -- & 46 & 10 & 0 & 0 & 0.01 \\
\hline
\end{tabular}

concentration of these three pesticides was less than 1.0 $\mu \mathrm{g} / \mathrm{L}$, with the exception of prometon $(2.4 \mu \mathrm{g} / \mathrm{L})$.

The pesticide having the highest percentage of samples above the detection limit was prometon (20 percent). The concentrations ranged from 0.1 at site 83 to $2.4 \mu \mathrm{g} / \mathrm{L}$ at site 86 . Of the other six pesticides that had detectable concentrations, only atrazine (15.8 percent) was found in more than 10 percent of the samples. Four other pesticides were detected in more than
5 percent of the samples: propazine (6.7), simazine (6.7), metolachlor (5.4), and alachlor (5.2).

\section{Bed Sediment}

A statistical summary of pesticide data collected at 55 bed-sediment sampling sites for 41 pesticides is shown in table 11 . Twenty-six of the 41 pesticides 
Table 10. Statistical summary of pesticide data from ground-water sampling sites for water years 1970-90

[STORET parameter code, U.S. Environmental Protection Agency's Storage and Retrieval code assigned to a parameter based on factors including the medium type and the analytical method used for the analysis; $\mu \mathrm{g} / \mathrm{L}$, micrograms per liter; --, data unavailable; ww, whole water]

\begin{tabular}{|c|c|c|c|c|c|c|c|c|c|}
\hline \multirow[b]{2}{*}{$\begin{array}{l}\text { STORET } \\
\text { para- } \\
\text { meter } \\
\text { code }\end{array}$} & \multirow[b]{2}{*}{ Parameter name } & \multicolumn{3}{|c|}{$\begin{array}{l}\text { Detected concentration } \\
(\mu \mathrm{g} / \mathrm{L})\end{array}$} & \multicolumn{4}{|c|}{ Number of } & \multirow[b]{2}{*}{$\begin{array}{c}\text { Maximum } \\
\text { detection } \\
\text { limit } \\
(\mu \mathrm{g} / \mathrm{L})\end{array}$} \\
\hline & & $\begin{array}{l}\text { Mini- } \\
\text { mum }\end{array}$ & Median & $\begin{array}{l}\text { Maxi- } \\
\text { mum }\end{array}$ & samples & sites & $\begin{array}{c}\text { sites with } \\
\text { a detectable } \\
\text { concentration }\end{array}$ & $\begin{array}{l}\text { samples with } \\
\text { a detectable } \\
\text { concentration }\end{array}$ & \\
\hline 39740 & $2,4,5-\mathrm{T}$, total & -- & -- & -- & 21 & 15 & 0 & 0 & 0.2 \\
\hline 39730 & $2,4-\mathrm{D}$, total & -- & -- & -- & 22 & 16 & 0 & 0 & 0.4 \\
\hline 39770 & $\begin{array}{l}\text { DCPA, unfiltered, } \\
\text { recoverable }\end{array}$ & -- & -- & -- & 6 & 6 & 0 & 0 & 0.05 \\
\hline 39360 & DDD, total & -- & -- & -- & 6 & 5 & 0 & 0 & 0.05 \\
\hline 39365 & DDE, total & -- & -- & -- & 6 & 5 & 0 & 0 & 0.05 \\
\hline 39370 & DDT, total & -- & -- & -- & 6 & 5 & 0 & 0 & 0.05 \\
\hline 39305 & o,p'-DDT, total & -- & -- & -- & 6 & 6 & 0 & 0 & 0.1 \\
\hline 39310 & p,p'-DDD, total & -- & -- & -- & 10 & 10 & 0 & 0 & 0.04 \\
\hline 39320 & p,p'-DDE, total & -- & -- & -- & 10 & 10 & 0 & 0 & 0.02 \\
\hline 39300 & p,p'-DDT, total & -- & -- & -- & 16 & 16 & 0 & 0 & 0.1 \\
\hline 34200 & Acenaphthylene, total & -- & -- & -- & 11 & 11 & 0 & 0 & 2.0 \\
\hline 77825 & $\begin{array}{l}\text { Alachlor, total, } \\
\text { recoverable }\end{array}$ & 0.1 & 0.51 & 0.93 & 96 & 76 & 5 & 5 & 0.25 \\
\hline 39330 & Aldrin, total & -- & -- & -- & 22 & 21 & 0 & 0 & 0.13 \\
\hline 39337 & Alpha BHC & -- & -- & -- & 10 & 10 & 0 & 0 & 0.13 \\
\hline 82184 & Ametryne, total & -- & -- & -- & 15 & 15 & 0 & 0 & 0.1 \\
\hline 39630 & Atrazine, total & 0.1 & 0.3 & 8.2 & 95 & 79 & 15 & 15 & 1.2 \\
\hline 39338 & $\begin{array}{l}\text { Beta benzene hexa- } \\
\text { chloride, total }\end{array}$ & -- & -- & -- & 10 & 10 & 0 & 0 & 0.25 \\
\hline 39350 & Chlordane, total & -- & -- & -- & 30 & 24 & 0 & 0 & 0.3 \\
\hline 81757 & Cyanazine, total & -- & -- & -- & 93 & 73 & 0 & 0 & 0.5 \\
\hline 39570 & Diazinon, total & -- & -- & -- & 21 & 14 & 0 & 0 & 0.2 \\
\hline 39380 & Dieldrin, total & -- & -- & -- & 22 & 21 & 0 & 0 & 0.1 \\
\hline 82624 & $\begin{array}{l}\text { Endosulfan II, ww, total } \\
\text { recoverable }\end{array}$ & -- & -- & -- & 10 & 10 & 0 & 0 & 0.00 \\
\hline 34351 & Endosulfan sulfate, total & -- & -- & -- & 10 & 10 & 0 & 0 & 0.1 \\
\hline 39390 & $\begin{array}{l}\text { Endrin, unfiltered, } \\
\text { recoverable }\end{array}$ & -- & -- & -- & 23 & 22 & 0 & 0 & 0.1 \\
\hline 39420 & $\begin{array}{l}\text { Heptachlor epoxide, } \\
\text { total }\end{array}$ & -- & -- & -- & 15 & 14 & 0 & 0 & 0.1 \\
\hline 39410 & Heptachlor, total & -- & -- & -- & 16 & 15 & 0 & 0 & 0.1 \\
\hline 39700 & $\begin{array}{l}\text { Hexachlorobenzene, } \\
\text { total }\end{array}$ & -- & -- & -- & 11 & 10 & 0 & 0 & 2.0 \\
\hline 39340 & Lindane, total & -- & -- & -- & 13 & 12 & 0 & 0 & 0.1 \\
\hline 39530 & Malathion, total & -- & -- & -- & 13 & 8 & 0 & 0 & 0.5 \\
\hline
\end{tabular}


Table 10. Statistical summary of pesticide data from ground-water sampling sites for water years 1970-90--Continued

[STORET parameter code, U.S. Environmental Protection Agency's Storage and Retrieval code assigned to a parameter based on factors including the medium type and the analytical method used for the analysis; $\mu \mathrm{g} / \mathrm{L}$, micrograms per liter; --, data unavailable; ww, whole water]

\begin{tabular}{|c|c|c|c|c|c|c|c|c|c|}
\hline \multirow[b]{2}{*}{$\begin{array}{l}\text { STORET } \\
\text { para- } \\
\text { meter } \\
\text { code }\end{array}$} & \multirow[b]{2}{*}{ Parameter name } & \multicolumn{3}{|c|}{$\begin{array}{l}\text { Detected concentration } \\
(\mu \mathrm{g} / \mathrm{L})\end{array}$} & \multicolumn{4}{|c|}{ Number of } & \multirow[b]{2}{*}{$\begin{array}{c}\text { Maximum } \\
\text { detection } \\
\text { limit } \\
(\mu \mathrm{g} / \mathrm{L})\end{array}$} \\
\hline & & $\begin{array}{l}\text { Mini- } \\
\text { mum }\end{array}$ & Median & $\begin{array}{c}\text { Maxi- } \\
\text { mum }\end{array}$ & samples & sites & $\begin{array}{c}\text { sites with } \\
\text { a detectable } \\
\text { concentration }\end{array}$ & $\begin{array}{l}\text { samples with } \\
\text { a detectable } \\
\text { concentration }\end{array}$ & \\
\hline 39051 & Methomyl, total & -- & -- & -- & 9 & 5 & 0 & 0 & 5.0 \\
\hline 39480 & Methoxychlor, total & -- & -- & -- & 10 & 10 & 0 & 0 & 0.5 \\
\hline 39600 & Methyl parathion, total & -- & -- & -- & 12 & 8 & 0 & 0 & 0.2 \\
\hline 82612 & $\begin{array}{l}\text { Metolachlor ww, } \\
\text { total recoverable }\end{array}$ & 0.06 & 0.12 & 0.19 & 93 & 73 & 5 & 5 & 5.0 \\
\hline 82611 & $\begin{array}{l}\text { Metribuzin ww, } \\
\text { recoverable }\end{array}$ & -- & -- & 0.1 & 93 & 73 & 1 & 1 & 0.5 \\
\hline 39023 & Phorate, total & -- & -- & -- & 10 & 10 & 0 & 0 & 0.1 \\
\hline 39056 & Prometon, total & 0.1 & -- & 2.4 & 15 & 15 & 3 & 3 & 0.1 \\
\hline 39057 & Prometryne, total & -- & -- & -- & 15 & 15 & 0 & 0 & 0.1 \\
\hline 39024 & Propazine, total & -- & -- & 0.43 & 15 & 15 & 1 & 1 & 0.1 \\
\hline 39750 & Sevin, total & -- & -- & -- & 18 & 11 & 0 & 0 & 1.0 \\
\hline 39760 & Silvex, total & -- & -- & -- & 14 & 13 & 0 & 0 & 0.2 \\
\hline 39055 & Simazine, total & -- & -- & 0.18 & 15 & 15 & 1 & 1 & 0.1 \\
\hline 38887 & $\begin{array}{l}\text { Terbutryn, ww, } \\
\text { recoverable }\end{array}$ & -- & -- & -- & 14 & 14 & 0 & 0 & 0.05 \\
\hline 39400 & Toxaphene, total & -- & -- & -- & 29 & 25 & 0 & 0 & 2.0 \\
\hline 39030 & Trifluralin, total & -- & -- & -- & 79 & 72 & 0 & 0 & 0.1 \\
\hline
\end{tabular}

were below the detection limit for all the samples analyzed. Fifteen pesticides were detected in 39 samples collected from 19 sites. The locations of the 19 sites at which at least 1 pesticide was detected are shown in figure 7. Pesticides were detected in bed sediment in the Springfield and Salem Plateaus in the southern and extreme northeastern part of the study unit; however, spatial coverage of the sampling sites was limited.

Chlordane, found in 12 of 73 samples from 10 of 45 sites, was the pesticide that had the most number of detections. The concentration for chlordane in samples with detections ranged from 2.0 to $240 \mu \mathrm{g} / \mathrm{kg}$ (micrograms per kilogram). The chlordane sample having the maximum concentration was collected at Sugar Creek above the confluence with Romaine Creek, Mo. (site 52) in 1990. No other chlordane samples were collected at site 52 during the period of record. Other sites that had chlordane samples above the detection limit were: Buffalo River near Harriet, Ark. (site 1; 1 of 4 samples, 1982); North Sylamore
Creek near Fifty Six, Ark. (site 3; 1 of 8 samples, 1975); Illinois River near Tahlequah, Okla. (site 6; 3 of 6 samples, 1981-85); Illinois River near Watts, Okla. (site 16; 1 of 2 samples, 1986); Unnamed tributary of the Meramec River, Mo. (site 42; 1 of 1 sample, 1990); Meramec River below Fishpot Creek, Mo. (site 46; 1 of 1 sample, 1988); Grand Glaize Creek at Big Bend Road, Mo. (site 51; 1 of 1 sample, 1988); Grand Glaize Creek at Doughtery Ferry Road, Mo. (site 53; 1 of 1 sample, 1990); Grand Glaize Creek at Deitrich Road, Mo. (site 55; 1 of 1 sample, 1990).

Five other pesticides were detected more than once: DDT was detected in 5 of 48 samples from 5 of 19 sites; DDD was detected in 5 of 20 samples from 4 of 5 sites; p,p'-DDE was detected in 3 of 50 samples from 2 of 37 sites; DDE was detected in 3 of 20 samples from 2 of 5 sites; hexachlorobenzene was detected in 2 of 43 samples from 2 of 29 sites. The maximum concentration of these five pesticides was 
Table 11. Statistical summary of pesticide data from bed-sediment sampling sites for water years 1970-90

[STORET parameter code, U.S. Environmental Protection Agency's Storage and Retrieval code assigned to a parameter based on factors including the medium type and the analytical method used for the analysis; $\mu \mathrm{g} / \mathrm{kg}$, micrograms per kilogram; --, data unavailable]

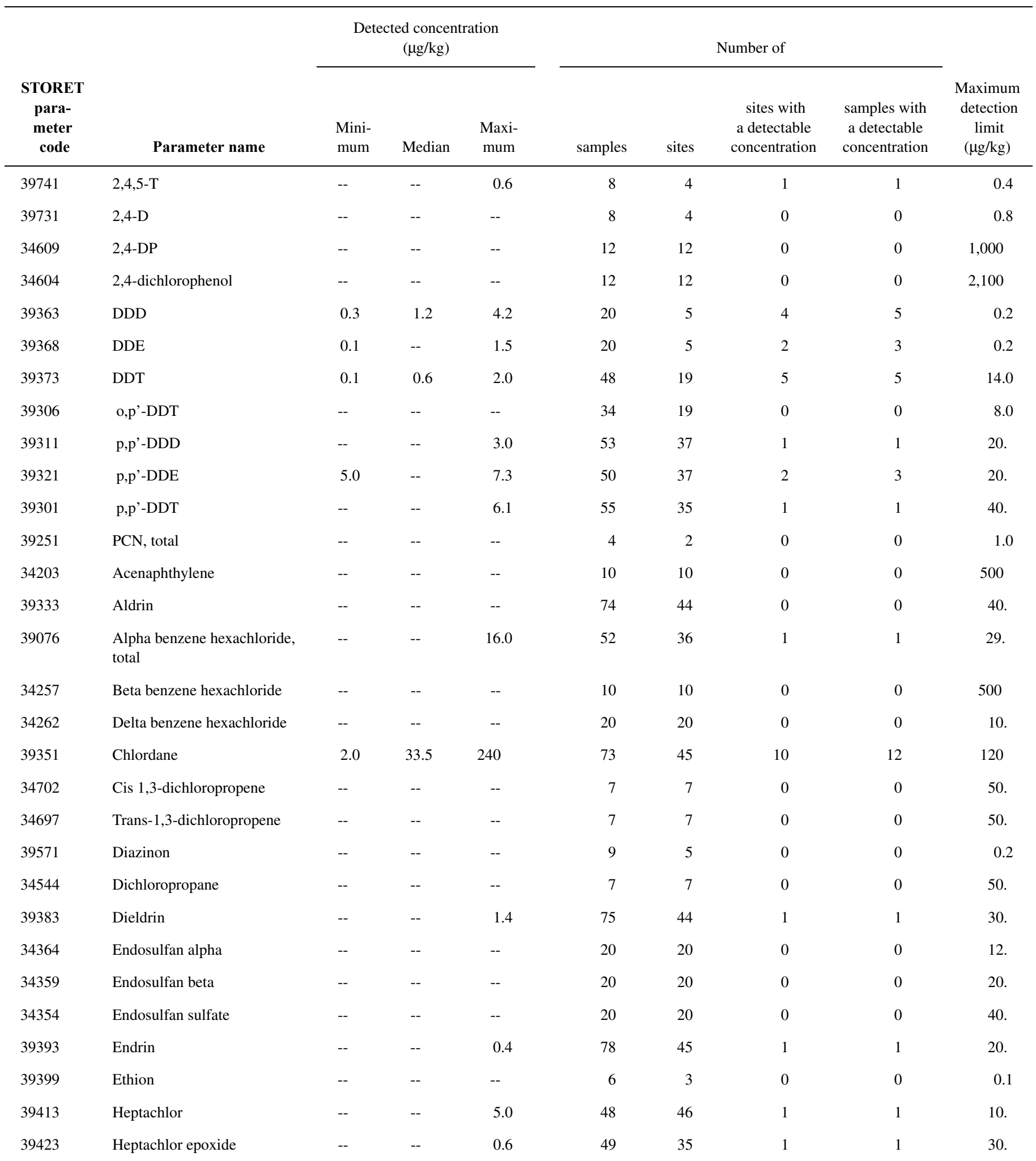


Table 11. Statistical summary of pesticide data from bed-sediment sampling sites for water years 1970-90--Continued

[STORET parameter code, U.S. Environmental Protection Agency's Storage and Retrieval code assigned to a parameter based on factors including the medium type and the analytical method used for the analysis; $\mu \mathrm{g} / \mathrm{kg}$, micrograms per kilogram; --, data unavailable]

\begin{tabular}{|c|c|c|c|c|c|c|c|c|c|}
\hline \multirow[b]{2}{*}{$\begin{array}{c}\text { STORET } \\
\text { para- } \\
\text { meter } \\
\text { code }\end{array}$} & \multirow[b]{2}{*}{ Parameter name } & \multicolumn{3}{|c|}{$\begin{array}{l}\text { Detected concentration } \\
(\mu \mathrm{g} / \mathrm{kg})\end{array}$} & \multicolumn{4}{|c|}{ Number of } & \multirow[b]{2}{*}{$\begin{array}{c}\text { Maximum } \\
\text { detection } \\
\text { limit } \\
(\mu \mathrm{g} / \mathrm{kg})\end{array}$} \\
\hline & & $\begin{array}{l}\text { Mini- } \\
\text { mum }\end{array}$ & Median & $\begin{array}{l}\text { Maxi- } \\
\text { mum }\end{array}$ & samples & sites & $\begin{array}{c}\text { sites with } \\
\text { a detectable } \\
\text { concentration }\end{array}$ & $\begin{array}{l}\text { samples with } \\
\text { a detectable } \\
\text { concentration }\end{array}$ & \\
\hline 39701 & Hexachlorobenzene & 1.0 & -- & 600 & 43 & 29 & 2 & 2 & 600 \\
\hline 39343 & Lindane & -- & -- & -- & 41 & 26 & 0 & 0 & 10. \\
\hline 39531 & Malathion & -- & -- & -- & 10 & 5 & 0 & 0 & 0.2 \\
\hline 39481 & Methoxychlor & -- & -- & 0.3 & 44 & 25 & 1 & 1 & 91. \\
\hline 39601 & Methyl parathion & -- & -- & -- & 12 & 6 & 0 & 0 & 0.2 \\
\hline 39791 & Methyl trithion & -- & -- & -- & 6 & 3 & 0 & 0 & 0.1 \\
\hline 39758 & Mirex & -- & -- & -- & 4 & 2 & 0 & 0 & 0.1 \\
\hline 39541 & Parathion & -- & -- & -- & 12 & 5 & 0 & 0 & 0.2 \\
\hline 81886 & Perthane & -- & -- & -- & 4 & 2 & 0 & 0 & 1.0 \\
\hline 39761 & Silvex & -- & -- & -- & 8 & 4 & 0 & 0 & 0.3 \\
\hline 39403 & Toxaphene & -- & -- & -- & 55 & 38 & 0 & 0 & 1,300 \\
\hline
\end{tabular}

less than $10 \mu \mathrm{g} / \mathrm{kg}$, with the exception of hexachlorobenzene $(600 \mu \mathrm{g} / \mathrm{kg})$.

The pesticide having the highest percentage of samples above the detection limit was DDD (25 percent). Four other pesticides had more than 10 percent of the samples above the detection limit: chlordane (16 percent), DDE (15 percent), 2,4,5-T (12.5 percent), and DDT (10.4 percent). Of the other 10 pesticides, which had detectable concentrations, only p,p'DDE (6 percent) and hexachlorobenzene (4.7 percent) were detected in more than 3 percent of the samples.

\section{Biological Tissue}

A statistical summary of pesticide data collected at 120 biological-tissue sampling sites for 43 pesticides is shown in table 12 . It is likely that a variety of species, ages, sizes, and tissue types (whole organisms, fillets, and specific organs) is represented in these data; all of these factors affect data comparability. Twenty of the 43 pesticides were below the detection limit for all the samples analyzed. Twentythree pesticides were detected in 798 samples col- lected from 61 sites. The locations of the 61 sites at which at least 1 pesticide was detected are shown in figure 8. Pesticides were detected in most areas of the study unit where sampling sites are located; the extreme northeastern part of the study unit had the greatest density of sites with detectable concentrations.

Chlordane, found in 93 of 151 samples at 39 of 53 sites, was the pesticide that had the most number of detections. The concentration of chlordane in samples with detections ranged from 0.009 to 8.6 milligrams per kilogram $(\mathrm{mg} / \mathrm{kg})$. The chlordane sample having the maximum concentration was collected at the Meramec River at Fenton, Mo. (site 106) in 1984. Site 106 had one other detection of chlordane in 1985. Other sites that had tissue samples with chlordane concentrations equal to or greater than $1 \mathrm{mg} / \mathrm{kg}$ were: Cow Creek 1 mile east of Langdon, Kans. (site 70; 1 of 2 samples, 1988); Meramec River 1 mile upstream of Mississippi River confluence, Mo. (site 90; 1 of 1 sample, 1984); and Romaine Creek upstream of Highway 141 Bridge, Mo. (site 96; 1 of 1 sample, 1984).

Four other pesticides were detected in 75 or more samples: p,p'-DDE was detected in 92 of 151 samples from 37 of 49 sites; chlordane-cis isomer was detected in 88 of 157 samples from 38 of 58 sites; 
Table 12. Statistical summary of pesticide data from biological-tissue sampling sites for water years 1970-90

[STORET parameter code, U.S. Environmental Protection Agency's Storage and Retrieval code assigned to a parameter based on factors including the medium type and the analytical method used for the analysis; $\mathrm{mg} / \mathrm{kg}$, milligrams per kilogram; --, data unavailable]

\begin{tabular}{|c|c|c|c|c|c|c|c|c|c|}
\hline \multirow[b]{2}{*}{$\begin{array}{c}\text { STORE } \\
\text { T } \\
\text { para- } \\
\text { meter } \\
\text { code }\end{array}$} & \multirow[b]{2}{*}{ Parameter name } & \multicolumn{3}{|c|}{$\begin{array}{l}\text { Detected concentration } \\
(\mathrm{mg} / \mathrm{kg})\end{array}$} & \multicolumn{4}{|c|}{ Number of } & \multirow[b]{2}{*}{$\begin{array}{c}\text { Maximum } \\
\text { detection } \\
\text { limit } \\
(\mathrm{mg} / \mathrm{kg})\end{array}$} \\
\hline & & $\begin{array}{l}\text { Mini- } \\
\text { mum }\end{array}$ & Median & $\begin{array}{c}\text { Maxi- } \\
\text { mum }\end{array}$ & samples & sites & $\begin{array}{c}\text { sites with } \\
\text { a detectable } \\
\text { concentration }\end{array}$ & $\begin{array}{l}\text { samples with } \\
\text { a detectable } \\
\text { concentration }\end{array}$ & \\
\hline 34545 & 1,2-dichloropropane & -- & -- & -- & 48 & 17 & 0 & 0 & 0.01 \\
\hline 34605 & 2,4-dichlorophenol & -- & -- & -- & 50 & 19 & 0 & 0 & 2.0 \\
\hline 34204 & Acenaphthylene & -- & -- & -- & 21 & 11 & 0 & 0 & 2.0 \\
\hline 82571 & Alachlor & -- & -- & -- & 46 & 16 & 0 & 0 & 0.08 \\
\hline 34680 & Aldrin, fish & -- & -- & 0.04 & 57 & 23 & 1 & 1 & 0.08 \\
\hline 39334 & Aldrin, shellfish or animal & -- & -- & -- & 18 & 3 & 0 & 0 & 6.0 \\
\hline 82404 & Atrazine, fish & -- & -- & -- & 69 & 29 & 0 & 0 & 0.38 \\
\hline 39074 & Alpha benzene hexachloride & 0.004 & 0.009 & 4.51 & 147 & 47 & 10 & 11 & 0.04 \\
\hline 34258 & Beta benzene hexachloride & -- & -- & -- & 50 & 18 & 0 & 0 & 0.04 \\
\hline 34263 & Delta benzene hexachloride & -- & -- & -- & 50 & 18 & 0 & 0 & 0.08 \\
\hline 34682 & Chlordane & 0.009 & 0.16 & 8.6 & 151 & 53 & 39 & 93 & 0.8 \\
\hline 39063 & Chlordane-cis isomer & 0.003 & 0.021 & 21.0 & 157 & 58 & 38 & 88 & 0.13 \\
\hline 39072 & $\begin{array}{l}\text { Chlordane-nonachlor, trans } \\
\text { isomer }\end{array}$ & 0.003 & 0.021 & 0.82 & 143 & 47 & 35 & 85 & 0.2 \\
\hline 39066 & Chlordane-trans isomer & 0.002 & 0.019 & 18.2 & 146 & 49 & 35 & 75 & 0.13 \\
\hline 34703 & $\begin{array}{l}\text { Cis-1,3-dichloropropene, } \\
\text { fish }\end{array}$ & -- & -- & -- & 20 & 9 & 0 & 0 & 0.02 \\
\hline 34698 & $\begin{array}{l}\text { Trans-1,3-dichloropropene, } \\
\text { fish }\end{array}$ & -- & -- & -- & 20 & 9 & 0 & 0 & 0.02 \\
\hline 39358 & DDT, total, aquatic organisms & 0.1 & 0.835 & 330 & 21 & 3 & 3 & 10 & 40. \\
\hline 39307 & o,p'-DDT & -- & -- & -- & 123 & 35 & 0 & 0 & 0.1 \\
\hline 39312 & $\mathrm{p}, \mathrm{p}$ '-DDD & 0.01 & 0.045 & 0.24 & 140 & 44 & 15 & 22 & 0.24 \\
\hline 39302 & p,p'-DDT & 0.01 & 0.05 & 0.2 & 149 & 46 & 12 & 14 & 0.4 \\
\hline 39322 & $\mathrm{p}, \mathrm{p}$ '-DDE & 0.01 & 0.03 & 52.7 & 151 & 49 & 37 & 92 & 0.16 \\
\hline 39404 & Dieldrin & 0.01 & 0.02 & 125 & 150 & 49 & 19 & 41 & 0.12 \\
\hline 34355 & Endosulfan sulfate & -- & -- & -- & 91 & 29 & 0 & 0 & 0.8 \\
\hline 34365 & Endosulfan, alpha & -- & -- & -- & 96 & 29 & 0 & 0 & 0.12 \\
\hline 34360 & Endosulfan, beta & -- & -- & 0.05 & 91 & 29 & 1 & 1 & 0.24 \\
\hline 34685 & Endrin & 0.275 & -- & 0.275 & 117 & 37 & 3 & 3 & 0.2 \\
\hline 39397 & Endrin, shellfish or animal & -- & -- & -- & 18 & 3 & 0 & 0 & 6.0 \\
\hline 34687 & Heptachlor & 0.002 & 0.005 & 0.11 & 102 & 31 & 5 & 5 & 8.0 \\
\hline 34686 & Heptachlor epoxide & 0.002 & 0.008 & 9.34 & 105 & 33 & 18 & 29 & 0.15 \\
\hline
\end{tabular}


Table 12. Statistical summary of pesticide data from biological-tissue sampling sites for water years 1970-90--Continued

[STORET parameter code, U.S. Environmental Protection Agency's Storage and Retrieval code assigned to a parameter based on factors including the medium type and the analytical method used for the analysis; $\mathrm{mg} / \mathrm{kg}$, milligrams per kilogram; --, data unavailable]

\begin{tabular}{|c|c|c|c|c|c|c|c|c|c|}
\hline \multirow[b]{2}{*}{$\begin{array}{c}\text { STORE } \\
T \\
\text { para- } \\
\text { meter } \\
\text { code }\end{array}$} & \multirow[b]{2}{*}{ Parameter name } & \multicolumn{3}{|c|}{$\begin{array}{l}\text { Detected concentration } \\
\qquad(\mathrm{mg} / \mathrm{kg})\end{array}$} & \multicolumn{4}{|c|}{ Number of } & \multirow[b]{2}{*}{$\begin{array}{c}\text { Maximum } \\
\text { detection } \\
\text { limit } \\
(\mathrm{mg} / \mathrm{kg})\end{array}$} \\
\hline & & $\begin{array}{l}\text { Mini- } \\
\text { mum }\end{array}$ & Median & $\begin{array}{c}\text { Maxi- } \\
\text { mum }\end{array}$ & samples & sites & $\begin{array}{c}\text { sites with } \\
\text { a detectable } \\
\text { concentration }\end{array}$ & $\begin{array}{l}\text { samples with } \\
\text { a detectable } \\
\text { concentration }\end{array}$ & \\
\hline 34688 & Hexachlorobenzene & 0.001 & 0.002 & 1.37 & 78 & 30 & 4 & 6 & 2.0 \\
\hline 39785 & Lindane & 0.01 & 0.025 & 3.19 & 99 & 31 & 6 & 8 & 0.02 \\
\hline 39534 & Malathion & -- & -- & -- & 10 & 3 & 0 & 0 & 0.1 \\
\hline 39482 & Methoxychlor, fish & -- & -- & -- & 27 & 10 & 0 & 0 & 100 \\
\hline 81644 & Methoxychlor, fish & -- & -- & -- & 39 & 14 & 0 & 0 & 0.2 \\
\hline 39346 & Metolachlor & -- & -- & -- & 41 & 16 & 0 & 0 & 0.5 \\
\hline 82405 & Metribuzin & 0.019 & 0.054 & 0.29 & 87 & 39 & 5 & 11 & 0.2 \\
\hline 81645 & Mirex, fish & -- & -- & 0.57 & 15 & 9 & 1 & 1 & 0.25 \\
\hline 82029 & Oxychlordane & 0.003 & 0.014 & 6.75 & 57 & 20 & 10 & 18 & 0.02 \\
\hline 81810 & Parathion, fish & -- & -- & -- & 6 & 3 & 0 & 0 & 0.1 \\
\hline 82533 & Propazine, fish & -- & -- & -- & 36 & 17 & 0 & 0 & 0.05 \\
\hline 82406 & Simazine, fish & 0.2 & 0.32 & 0.45 & 211 & 51 & 3 & 7 & 3.8 \\
\hline 34691 & Toxaphene & -- & -- & 1.5 & 72 & 25 & 1 & 1 & 6.5 \\
\hline 39407 & Toxaphene, fish & -- & -- & 424. & 9 & 2 & 1 & 1 & 60. \\
\hline
\end{tabular}

chlordane-nonachlor-trans isomer was detected in 85 of 143 samples from 35 of 47 sites; and chlordane-trans isomer was detected in 75 of 146 samples from 35 of 49 sites. The maximum concentrations of these four pesticides were $52.7,21.0,0.82$, and $18.2 \mathrm{mg} / \mathrm{kg}$, respectively. The samples having the maximum concentration of these four pesticides were collected prior to 1987. Twelve other pesticides were detected in 5 or more samples.

The pesticide having the highest percentage of samples above the detection limit was chlordane (61.6 percent). Four other pesticides were detected in 50 percent or more of the samples: p,p'-DDE, chlordanenonachlor (trans isomer), chlordane-cis isomer, chlordane-trans isomer.

\section{Comparison of Pesticide Data with Selected Quality Criteria and Standards}

Fifteen pesticides detected at sites in the study unit have quality criteria (nonenforceable suggested values) or standards (legally enforceable values) established for one or more sample types. The maximum concentrations of these pesticides in surfacewater, ground-water, bed-sediment, and biological-tissue samples summarized in this report are compared with selected quality criteria and standards established by the U.S. Environmental Protection Agency (USEPA) and U.S. Food and Drug Administration (USFDA) in table 13.

For surface water, the Acute Aquatic Life Criteria (AALC) established by the USEPA (Nowell and Resek, 1994) provide a basis of comparison with the maximum concentration of the detected pesticides having an AALC value. None of the four detected pesticides having an AALC value (chlordane, DDT, dieldrin, or heptachlor) exceeded their respective AALC.

The drinking water Maximum Contaminant Level (MCL) established by the USEPA (Nowell and Resek, 1994) provides a basis of comparison with the maximum concentration of detected pesticides having 
Table 13. Comparison of selected quality criteria and standards with maximum detected concentrations in surface-water, ground-water, bed-sediment, and biological-tissue samples

[Maximum concentration, maximum concentration of samples given in this report; AALC, Acute Aquatic Life Criteria; MCL, Maximum Contaminant Level; SQC, Sediment Quality Criteria; FTAL, Fish Tissue Action Level; $\mu \mathrm{g} / \mathrm{L}$, micrograms per liter; $\mu \mathrm{g} / \mathrm{kg}$, micrograms per kilogram; mg/kg, milligrams per kilogram; --, data unavailable; nsg, no standard or guideline established]

\begin{tabular}{|c|c|c|c|c|c|c|c|c|}
\hline \multirow[b]{2}{*}{ Parameter name } & \multicolumn{2}{|c|}{ Surface water } & \multicolumn{2}{|c|}{ Ground water } & \multicolumn{2}{|c|}{ Bed sediment } & \multicolumn{2}{|c|}{ Biological Tissue } \\
\hline & $\begin{array}{c}\text { Maxi- } \\
\text { mum } \\
\text { concen- } \\
\text { tration } \\
(\mu \mathrm{g} / \mathrm{L})\end{array}$ & $\begin{array}{c}\mathbf{A A L C}^{1} \\
(\mu \mathrm{g} / \mathrm{L})\end{array}$ & $\begin{array}{c}\text { Maxi- } \\
\text { mum } \\
\text { concen- } \\
\text { tration } \\
(\mu \mathrm{g} / \mathrm{L})\end{array}$ & $\begin{array}{c}\text { Drinking } \\
\text { water } \\
\text { standard } \\
\text { MCL }^{1,2} \\
(\mu \mathrm{g} / \mathrm{L})\end{array}$ & $\begin{array}{l}\text { Maxi- } \\
\text { mum } \\
\text { concen- } \\
\text { tration } \\
(\mu \mathrm{g} / \mathrm{kg})\end{array}$ & $\begin{array}{c}\text { SQC }^{1} \\
(\mu \mathrm{g} / \mathrm{kg})\end{array}$ & $\begin{array}{l}\text { Maxi- } \\
\text { mum } \\
\text { concen- } \\
\text { tration } \\
\text { (mg/kg) }\end{array}$ & $\begin{array}{c}\text { FTAL }^{1,3} \\
(\mathrm{mg} / \mathrm{kg})\end{array}$ \\
\hline Alachlor & 4.2 & nsg & 0.93 & 2.0 & -- & nsg & -- & nsg \\
\hline Aldrin & 0.001 & nsg & -- & nsg & -- & nsg & 0.04 & 0.3 \\
\hline Atrazine & -- & nsg & 8.2 & 3.0 & -- & nsg & -- & nsg \\
\hline Chlordane & 0.5 & 2.4 & -- & 2.0 & 240 & 309 & 8.6 & 0.3 \\
\hline DDT total & 0.023 & 1.1 & -- & -- & -- & nsg & 330 & nsg \\
\hline Dieldrin & 0.01 & 2.5 & -- & nsg & 1.4 & 11,000 & 125 & 0.3 \\
\hline Endrin & -- & 0.18 & -- & 2.0 & 0.4 & 4,200 & 0.275 & 0.3 \\
\hline Heptachlor & 0.23 & 0.52 & -- & 0.4 & 5 & 110 & 0.11 & 0.3 \\
\hline Heptachlor epoxide & -- & 0.52 & -- & 0.2 & 0.6 & $\mathrm{nsg}$ & 9.34 & 0.3 \\
\hline Mirex & -- & nsg & -- & nsg & -- & nsg & 0.57 & 0.1 \\
\hline $\mathrm{p}, \mathrm{p}^{\prime}-\mathrm{DDD}$ & -- & nsg & -- & nsg & 3 & nsg & 0.24 & 5 \\
\hline $\mathrm{p}, \mathrm{p}$-DDT & -- & nsg & -- & nsg & 6.1 & 828 & 0.2 & 5 \\
\hline $\mathrm{p}, \mathrm{p}$ '-DDE & -- & nsg & -- & nsg & 7.3 & nsg & 52.7 & 5 \\
\hline Simazine & -- & nsg & 0.18 & 4.0 & -- & nsg & 0.45 & nsg \\
\hline Toxaphene & 6.0 & nsg & -- & 3.0 & -- & 64.7 & 424 & 5,000 \\
\hline
\end{tabular}

a MCL value. Because the MCL applies to finished drinking water, the comparison of concentrations of detected pesticides in this report with the MCL is merely for informational purposes. Alachlor, the only pesticide detected in surface water that exceeded its MCL, was detected in one sample in 1982 collected at site 109 (figure 5 and table 5), which is located in the Osage Plains in the northwestern part of the study unit. Of the three pesticides detected in ground water that have an established MCL, only atrazine exceeded the MCL value of $3.0 \mu \mathrm{g} / \mathrm{L}$. The sites where atrazine concentrations exceeded the drinking water MCL were: sites 79, 80, 88, 91 (fig. 6 and table 6). All four samples (one from each site) were collected in 1990 at sites located in the Osage Plains in the northwestern part of the study unit.

For bed sediment, the Sediment Quality Criteria (SQC) developed by the USEPA (Nowell and Resek, 1994) provides a basis of comparison with the maximum concentration of detected pesticides having a SQC value. None of the five detected pesticides having a SQC value (chlordane, dieldrin, endrin, heptachlor, p,p'-DDT) exceeded their respective SQC.

For biological tissue, the Fish Tissue Action Level (FTAL) established by the USFDA (Nowell and Resek, 1994) provides a basis of comparison with the 
maximum concentration of detected pesticides having a FTAL value. Five pesticides exceeded their respective FTAL. Chlordane concentrations in 26 samples from 19 sites $(40,45,46,47,59,63,70,74,81,85$, 90, 91, 92, 93, 96, 104, 106, 108, 112; fig. 8, table 8) exceeded the FTAL value of $0.3 \mathrm{mg} / \mathrm{kg}$. Heptachlor epoxide concentrations in three samples (sites 10, 78, 101) exceeded the FTAL value of $0.3 \mathrm{mg} / \mathrm{kg}$. Concentrations of p,p'-DDE in two samples (sites 10,78) exceeded the FTAL value of $5 \mathrm{mg} / \mathrm{kg}$. Dieldrin concentrations in two samples (sites 10,78) exceeded the FTAL value of $0.3 \mathrm{mg} / \mathrm{kg}$. The concentration of mirex in one sample (site 10) exceeded the FTAL value of $0.1 \mathrm{mg} / \mathrm{kg}$. The samples with chlordane concentrations exceeding the FTAL were from primarily the Salem Plateau in the extreme northeastern part of the study unit. The samples with heptachlor epoxide, p,p'DDE, dieldrin, and mirex concentrations exceeding the FTAL were from the southwestern, northwestern, and northeastern parts of the study unit. All the samples with concentrations exceeding their respective FTAL were collected in 1986-87, except for samples with chlordane, which were collected during the years 1982-89.

The comparison of detected pesticides with selected quality criteria and standards indicates that pesticides do not pose any widespread or persistent problems in the study unit, although a complete evaluation is not possible because of the limited spatial and temporal distribution of samples. Two criteria, the AALC (for surface water) and the SQC (for bed sediment) were not exceeded by any samples and the MCL (for surface and ground water) was exceeded in only five samples, all from sites in the northwestern part of the study unit. The FTAL value (for biological tissue) was exceeded by five pesticides, but only chlordane exceeded its FTAL in more than three samples, all from sites in the extreme northeastern part of the study unit.

\section{SUMMARY}

Approximately 4.2 million pounds per year of active ingredients from 24 pesticides were applied on 20 crop types within the study unit from 1982-85. Only 6 of the 24 pesticides were used extensively throughout the study unit and these account for approximately 88 percent of the total pesticides applied. Pesticide use generally was greatest in areas where the dominant land use was pastureland in the Springfield and Salem Plateaus and in cropland areas in the Osage Plains and Mississippi Alluvial Plain. The most frequently applied pesticide in the study unit was 2,4-D. Alachlor was the second most applied pesticide.

Five crop types received approximately 90 percent of the pesticides applied within the study unit: corn, pasture, rice, sorghum, and soybeans. The highest use occurred on these crops in the Mississippi Alluvial Plain and Osage Plains. Pastureland located in the Springfield and Salem Plateaus received moderate amounts of pesticides. Forestland and pastureland in the Boston and St. Francois Mountains received the least amounts of pesticides. Pastureland was the predominant crop type in 50 of the 94 counties in the study unit based on crop estimates accompanying the pesticide-use data.

Pesticide data are available for 1,002 samples from 140 surface-water sites within the study unit. Surface-water sites have drainage basins primarily in the Springfield (45 sites) and Salem (43 sites) Plateaus. Many surface-water sites were sampled only once (42 sites) or twice (19 sites) during the 1970-90 period of record. About 50 percent of the 1,002 samples were collected in the mid-1970's and early 1980's.

Pesticide data are available for 103 samples from 92 ground-water sites (90 wells; 2 springs) within the study unit. Most of the sites (94 percent) are located in the northwestern or southeastern parts of the study unit. Most ground-water sites were sampled only once ( 85 sites) or twice ( 3 sites) during the 1970-90 period of record. Sixty percent of the samples were collected in 1990 in a study by Ziegler and others (1994) in the northwestern part of the study unit.

Pesticide data are available for 87 samples from 55 bed-sediment sites within the study unit. Bed-sediment sites have drainage basins predominately in the southern and extreme northeastern Salem Plateau (16 sites), and the Springfield Plateau (14 sites). Most bed-sediment sites were sampled only once (42 sites) or twice (8 sites) during the 1970-90 period of record. About 40 percent of the 87 samples were collected during the late 1980 's.

Pesticide data are available for 431 biologicaltissue (fish and shellfish) samples from 120 sites within the study unit. Most biological-tissue sampling sites have drainage basins in the Salem Plateau (47 
sites) and Springfield Plateau (35 sites). Many biological-tissue sites were sampled only once (51 sites) or twice (20 sites) during the period of record. About 50 percent of the 431 samples were collected between 1981-86.

Pesticide data collected at 140 surface-water sites for 51 pesticides are summarized in this report. Thirty-five pesticides were below the detection limit in all the samples analyzed. One or more of 16 pesticides were detected in 132 samples collected from 43 sites. Toxaphene, found in 17 of 866 samples from 5 of 112 sites, was the pesticide that had the most number of detections. The concentration of toxaphene in samples with detections ranged from 0.1 to $6.0 \mu \mathrm{g} / \mathrm{L}$. Six other pesticides were detected in 12 or more samples: DDE, dieldrin, DDT, aldrin, 2,4-D, and lindane. The maximum concentration for these six pesticides was less than $1.0 \mu \mathrm{g} / \mathrm{L}$.

Pesticide data collected at 92 ground-water sites for 44 pesticides are summarized in this report. The concentrations of 37 pesticides were below the detection limit in all the samples analyzed. One or more of 7 pesticides were detected in 31 samples collected from 18 sites. All 31 samples with detectable concentrations were collected in 1990. Atrazine, found in 15 of 95 samples from 15 of 79 wells, was the pesticide that had the most number of detections. The concentration of atrazine in samples with detections ranged from 0.1 to $8.2 \mu \mathrm{g} / \mathrm{L}$. Three other pesticides were detected more than once: metolachlor, alachlor, and prometon. The maximum concentration for these three pesticides was less than $1.0 \mu \mathrm{g} / \mathrm{L}$, with the exception of prometon $(2.4 \mu \mathrm{g} / \mathrm{L})$.

Pesticide data collected at 55 bed-sediment sites for 41 pesticides are summarized in this report. The concentrations of 26 pesticides were below the detection limit in all the samples analyzed. One or more of 15 pesticides were detected in 39 samples collected from 19 sites. Chlordane, found in 12 of 73 samples from 10 of 45 sites, was the pesticide that had the most number of detections. The concentration of chlordane in samples with detections ranged from 2.0 to $240 \mu \mathrm{g} / \mathrm{kg}$. Five other pesticides were detected more than once: DDT, DDD, p,p'-DDE, DDE, and hexachlorobenzene. The maximum concentration for these five pesticides was less than $10 \mu \mathrm{g} / \mathrm{kg}$, with the exception of hexachlorobenzene $(600 \mu \mathrm{g} / \mathrm{kg})$.

Pesticide data collected at 120 biological-tissue sites for 43 pesticides are summarized in this report. The concentrations of 20 pesticides were below the detection limit in all the samples analyzed. One or more of 23 pesticides were detected in 798 samples collected from 61 sites. Chlordane, found in 93 of 151 samples from 39 of 53 sites, was the pesticide that had the most number of detections. The concentration of chlordane in samples with detections ranged from 0.009 to $8.6 \mathrm{mg} / \mathrm{kg}$. Four other pesticides were detected in 75 or more samples: p,p'-DDE, chlordanecis isomer, chlordane-nonachlor-trans isomer, and chlordane-trans isomer. The maximum concentrations for these four pesticides were 52.7, 21.0, 0.82, and $18.2 \mathrm{mg} / \mathrm{kg}$, respectively. Twelve other pesticides were detected in 5 or more samples.

Quality criteria or standards have been established for 15 of the pesticides detected at sites in the study unit. For surface-water samples, the drinking water maximum contaminant level for alachlor was exceeded in one sample in 1982 from one site located in the northwestern part of the study unit in the Osage Plains. For ground-water samples, the drinking water maximum contaminant level for atrazine was exceeded in four samples from four wells in 1990. The four wells are located in the northwestern part of the study unit in the Osage Plains. For biological-tissue samples, the fish tissue action levels for chlordane (26 samples; 19 sites), heptachlor epoxide (3 sites; 3 samples), p,p'-DDE (2 sites; 2 samples), dieldrin ( 2 sites; 2 samples), and mirex (1 site; 1 sample) were exceeded. These sites are located primarily in the northeastern part of the study unit. All the samples exceeding the fish tissue action levels were collected in 1982-89. For bed-sediment samples, quality criteria or standards were not exceeded for any pesticide. Pesticides do not pose any widespread or persistent problems in the study unit, based on the limited number of samples that exceeded quality criteria and standards.

\section{SELECTED REFERENCES}

Adamski, J.C., Petersen, J.C., Freiwald, D.A., and Davis, J.V., 1995, Environmental and hydrologic setting of the Ozark Plateaus study unit, Arkansas, Kansas, Missouri, and Oklahoma: U.S. Geological Survey WaterResources Investigations Report 94-4022, 69 p.

Baldwin, F.L., Boyd, J.W., and Guy, C.B., 1994, Recommended chemicals for weed and brush control: University of Arkansas, Cooperative Extension Service, Report MP 44, 136 p. 
Becker, S.A., Smith, G.S., O’Day, M., and Jarman, J., 1992, Pesticide use surveys, Missouri, 1992: University of Missouri, Agricultural Statistics Service, 56 p.

Davis, J.V., Petersen, J.C., Adamski, J.C., and Freiwald, D.A., 1995, Water-quality assessment of the Ozark Plateaus study unit, Arkansas, Kansas, Missouri, and Oklahoma--analysis of information on nutrients, suspended sediment, and suspended solids, 1970-92: U.S. Geological Survey Water-Resources Investigations Report 95-4042, $112 \mathrm{p}$.

Dugan, J.T., and Peckenpaugh, J.M., 1985, Effects of climate, vegetation, and soils on consumptive water use and ground-water recharge to the Central Midwest Regional Aquifer System, Mid-Continent United States: U.S. Geological Survey Water-Resources Investigations Report 85-4236, $77 \mathrm{p}$.

Fenneman, N.M., 1938, Physiography of eastern United States: New York, McGraw-Hill Book Co., Inc., $689 \mathrm{p}$.

Gebert, W.A., Graczyk, D.J., and Krug, W.R., 1985, Average annual runoff in the United States, 1951-80: U.S. Geological Survey Open-File Report 85-627, scale 1:2,000,000.

Gianessi, L.P., and Puffer, C.A., 1988, Use of selected pesticides for agricultural crop production in the United States, 1982-85: Washington, D.C., Resources for the Future, $490 \mathrm{p}$.

Hanson, R.L., 1991, Hydrology of floods and droughts, evapotranspiration and droughts in National Water Summary 1988-89--Floods and Droughts: U.S. Geological Survey Water-Supply Paper 2375, p. 99-104.

Hoelman, L.H., II, compiler, 1989, STORET-Seminar documentation overview TSO: U.S. Environmental Protection Agency, p. 4.

Hutchison, N.E., compiler, 1975, WATSTORE user's guide--National water data storage and retrieval system: U.S. Geological Survey Open-File Report 75-426, v. 1, p. v-vi.

Imes, J.L., and Emmett, L.F., 1994, Geohydrology of the Ozark Plateaus aquifer system in parts of Missouri, Arkansas, Oklahoma, and Kansas: U.S. Geological Survey Professional Paper 1414-D, 127 p.

Johnson, D.R., and Jones, B.F., 1994, Insecticide recommendations for Arkansas - 1994: University of Arkansas, Cooperative Extension Service, Report MP 144, $132 \mathrm{p}$.

Nowell, L.H., and Resek, E.A., 1994, National standards and guidelines for pesticides in water, sediment and aquatic organisms: application to water-quality assessments, in Ware, G.W., ed., Reviews of environmental contamination and toxicology, v. 140: New York, Spring-Verlag, p. 1-64.
Sine, C., editor, 1991, Farm chemicals handbook: Willoughby, Ohio, Meister Publishing Company, [variously paged].

Spradley, P., 1991, Survey of pesticide use on the major vegetable crops in Arkansas - 1990: University of Arkansas, Cooperative Extension Service, Report ETB $173,52 \mathrm{p}$.

-----1992, Survey of pesticide use on the major fruit crops in Arkansas - 1991: University of Arkansas, Cooperative Extension Service, Report ETB 175, 71 p.

U.S. Department of Commerce, Bureau of Census, 1990, 1990 Census of population and housing summary population and housing characteristics--Arkansas, Kansas, Missouri, Oklahoma, [variously paged].

U.S. Geological Survey, 1990, Land use and land cover digital data from 1:250,000- and 1:100,000-scale maps: U.S. Geodata Users Guide 4, 33 p.

Ziegler, A.C., Wilkison, D.H., Maley, R.D., 1994, Occurrence of selected pesticides, nutrients, selected trace elements, and radionuclides in ground and surface water from west-central Missouri--July 1990-March 1991: U.S. Geological Survey Open-File Report 93$362,71 \mathrm{p}$. 


\section{TABLES}


Table 5. Site and basin characteristics of surface-water sampling sites

$\left[\mathrm{mi}^{2}\right.$, square mile; WY70-90, water years 1970-1990; --, data unavailable; ODEQ, Oklahoma Department of Environmental Quality; ADPCE, Arkansas Department of Pollution Control and Ecology; USGS, U.S. Geological Survey; USEPA, U.S. Environmental Protection Agency; KDHE, Kansas Department of Health and Environment; USCOE, U.S. Army Corps of Engineers]

\begin{tabular}{|c|c|c|c|c|c|c|c|c|}
\hline $\begin{array}{c}\text { Site } \\
\text { number }\end{array}$ & Site name & Latitude & Longitude & $\begin{array}{c}\text { Drainage } \\
\text { area } \\
\left(\mathbf{m i}^{2}\right)\end{array}$ & $\begin{array}{l}\text { Collecting } \\
\text { agency }\end{array}$ & Physiographic area ${ }^{1}$ & $\begin{array}{l}\text { Period of } \\
\text { record } \\
(\text { WY70-90) }\end{array}$ & $\begin{array}{c}\text { Number } \\
\text { of } \\
\text { samples }\end{array}$ \\
\hline 1 & $\begin{array}{l}\text { Illinois River at Highway } 64 \\
\text { Bridge, Okla. }\end{array}$ & 353100 & 950528 & -- & ODEQ & Springfield & $1979-90$ & 6 \\
\hline 2 & $\begin{array}{l}\text { White River at Oil Trough, } \\
\text { Ark. }\end{array}$ & 353836 & 912742 & -- & ADPCE & $\begin{array}{l}\text { Mississippi Alluvial Plain, } \\
\text { Boston, Salem, Spring- } \\
\text { field }\end{array}$ & $1974-87$ & 30 \\
\hline 3 & White River near Salado, Ark. & 354203 & 913319 & -- & ADPCE & $\begin{array}{l}\text { Boston, Salem, Spring- } \\
\text { field }\end{array}$ & 1984 & 1 \\
\hline 4 & $\begin{array}{l}\text { White River at Batesville, } \\
\text { Ark. }\end{array}$ & 354535 & 913828 & 11,070 & USGS & $\begin{array}{l}\text { Boston, Salem, Spring- } \\
\text { field }\end{array}$ & 1984 & 1 \\
\hline 5 & $\begin{array}{l}\text { White River above Batesville, } \\
\text { Ark. }\end{array}$ & 354537 & 913813 & -- & ADPCE & $\begin{array}{l}\text { Boston, Salem, Spring- } \\
\text { field }\end{array}$ & 1984 & 1 \\
\hline 6 & $\begin{array}{l}\text { Grand Neosho River near } \\
\text { Fort Gibson Dam, Okla. }\end{array}$ & 355115 & 951345 & -- & USEPA & Springfield, Osage Plains & $1980-81$ & 2 \\
\hline 7 & $\begin{array}{l}\text { Baron Fork at Dutch Mills, } \\
\text { Ark. }\end{array}$ & 355248 & 942911 & 41 & ADPCE & Springfield & $1972-85$ & 20 \\
\hline 8 & $\begin{array}{l}\text { Bear Creek west of Marshall, } \\
\text { Ark. }\end{array}$ & 355520 & 924220 & -- & ADPCE & Boston & 1985 & 1 \\
\hline 9 & $\begin{array}{l}\text { Illinois River near Tahlequah, } \\
\text { Okla. }\end{array}$ & 355522 & 945524 & 959 & $\begin{array}{l}\text { ODEQ, } \\
\text { USGS }\end{array}$ & Springfield & 1978-90 & 16 \\
\hline 10 & $\begin{array}{l}\text { Buffalo River near St. Joe, } \\
\text { Ark. }\end{array}$ & 355902 & 924444 & 829 & ADPCE & Boston, Springfield & $1974-85$ & 18 \\
\hline 11 & Buffalo River near Hasty, Ark. & 355903 & 930230 & -- & ADPCE & Boston, Springfield & $1974-77$ & 6 \\
\hline 12 & $\begin{array}{l}\text { North Sylamore Creek near } \\
\text { Fifty Six, Ark. }\end{array}$ & 355943 & 921245 & 58 & USGS & Springfield & $1970-81$ & 13 \\
\hline 13 & $\begin{array}{l}\text { White River below } \\
\text { Fayetteville, Ark. }\end{array}$ & 360000 & 940000 & -- & USEPA & Boston, Springfield & 1981 & 1 \\
\hline 14 & $\begin{array}{l}\text { Strawberry River near } \\
\text { Smithville, Ark. }\end{array}$ & 360140 & 911931 & -- & ADPCE & Salem & $1974-84$ & 15 \\
\hline 15 & $\begin{array}{l}\text { West Fork White River east } \\
\text { of Fayetteville, Ark. }\end{array}$ & 360300 & 940442 & -- & ADPCE & Boston, Springfield & $1974-85$ & 18 \\
\hline 16 & $\begin{array}{l}\text { Mill Creek near Melbourne, } \\
\text { Ark. }\end{array}$ & 360313 & 915458 & -- & ADPCE & Salem & 1984,85 & 2 \\
\hline 17 & $\begin{array}{l}\text { Buffalo River near Harriet, } \\
\text { Ark. }\end{array}$ & 360403 & 923438 & -- & USGS & Boston & $1979-82$ & 4 \\
\hline 18 & Illinois River at Savoy, Ark. & 360611 & 942039 & 167 & ADPCE & Springfield & $1974-84$ & 13 \\
\hline 19 & $\begin{array}{l}\text { Black River at Black Rock, } \\
\text { Ark. }\end{array}$ & 360615 & 910550 & 7,369 & USGS & $\begin{array}{l}\text { Mississippi Alluvial Plain, } \\
\text { Salem, St. Francois }\end{array}$ & 1970-79 & 7 \\
\hline 20 & $\begin{array}{l}\text { White River near Goshen, } \\
\text { Ark. }\end{array}$ & 360622 & 940041 & -- & ADPCE & Boston, Springfield & $1974-85$ & 19 \\
\hline 21 & $\begin{array}{l}\text { Illinois River south of Siloam } \\
\text { Springs, Ark. }\end{array}$ & 360631 & 943200 & -- & ADPCE & Springfield & $1972-81$ & 15 \\
\hline 22 & $\begin{array}{l}\text { White River at Calico Rock, } \\
\text { Ark. }\end{array}$ & 360658 & 920835 & 9,978 & USGS & $\begin{array}{l}\text { Salem, Boston, Spring- } \\
\text { field }\end{array}$ & $1974-79$ & 6 \\
\hline
\end{tabular}


Table 5. Site and basin characteristics of surface-water sampling sites--Continued

$\left[\mathrm{mi}^{2}\right.$, square mile; WY70-90, water years 1970-1990; --, data unavailable; ODEQ, Oklahoma Department of Environmental Quality; ADPCE, Arkansas Department of Pollution Control and Ecology; USGS, U.S. Geological Survey; USEPA, U.S. Environmental Protection Agency; KDHE, Kansas Department of Health and Environment; USCOE, U.S. Army Corps of Engineers]

\begin{tabular}{|c|c|c|c|c|c|c|c|c|}
\hline $\begin{array}{c}\text { Site } \\
\text { number }\end{array}$ & Site name & Latitude & Longitude & $\begin{array}{c}\text { Drainage } \\
\text { area } \\
\left(\mathbf{m i}^{2}\right)\end{array}$ & $\begin{array}{c}\text { Collecting } \\
\text { agency }\end{array}$ & Physiographic area ${ }^{1}$ & $\begin{array}{c}\text { Period of } \\
\text { record } \\
(\text { WY70-90) }\end{array}$ & $\begin{array}{c}\text { Number } \\
\text { of } \\
\text { samples }\end{array}$ \\
\hline 23 & $\begin{array}{l}\text { Holman Creek near } \\
\text { Huntsville, Ark. }\end{array}$ & 360725 & 934402 & -- & ADPCE & Boston & 1984,85 & 2 \\
\hline 24 & $\begin{array}{l}\text { Illinois River near Watts, } \\
\text { Okla. }\end{array}$ & 360748 & 943419 & 635 & USGS & Springfield & $1989-90$ & 9 \\
\hline 25 & $\begin{array}{l}\text { Illinois River near } \\
\text { Siloam Springs, Ark. }\end{array}$ & 360841 & 942941 & 509 & ADPCE & Springfield & $1982-85$ & 7 \\
\hline 26 & $\begin{array}{l}\text { Grand Neosho River above } \\
\text { Industrial Park, Okla. }\end{array}$ & 361051 & 951625 & -- & ODEQ & Springfield, Osage Plains & 1980,90 & 2 \\
\hline 27 & $\begin{array}{l}\text { Sager Creek near } \\
\text { Siloam Springs, Ark. }\end{array}$ & 361150 & 943500 & -- & ADPCE & Springfield & $1972-82$ & 20 \\
\hline 28 & Spring River at Imboden, Ark. & 361219 & 911019 & 1,183 & USGS & Salem & 1970,71 & 2 \\
\hline 29 & $\begin{array}{l}\text { North Fork River at } \\
\text { Norfork, Ark. }\end{array}$ & 361248 & 921654 & -- & ADPCE & Salem & $1974-82$ & 17 \\
\hline 30 & $\begin{array}{l}\text { Flint Creek near West } \\
\text { Siloam Springs, Okla. }\end{array}$ & 361258 & 943615 & -- & ADPCE & Springfield & $1982-85$ & 6 \\
\hline 31 & $\begin{array}{l}\text { Osage Creek near } \\
\text { Elm Springs, Ark. }\end{array}$ & 361319 & 941718 & 130 & ADPCE & Springfield & $1974-85$ & 16 \\
\hline 32 & $\begin{array}{l}\text { Crooked Creek at } \\
\text { Yellville, Ark. }\end{array}$ & 361323 & 924047 & 406 & ADPCE & Salem, Springfield & $1979-85$ & 11 \\
\hline 33 & $\begin{array}{l}\text { White River near } \\
\text { Norfork, Ark. }\end{array}$ & 361324 & 921806 & -- & ADPCE & $\begin{array}{l}\text { Salem, Boston, Spring- } \\
\text { field }\end{array}$ & $1974-87$ & 39 \\
\hline 34 & $\begin{array}{l}\text { Spring River at } \\
\text { Ravenden, Ark. }\end{array}$ & 361330 & 911503 & -- & ADPCE & Salem & $1974-84$ & 15 \\
\hline 35 & $\begin{array}{l}\text { Neosho River at State } \\
\text { Highway } 33 \text { Bridge, Okla. }\end{array}$ & 361345 & 951059 & -- & ODEQ & Springfield, Osage Plains & 1990 & 1 \\
\hline 36 & $\begin{array}{l}\text { Spavinaw Creek north of } \\
\text { Sycamore, Okla. }\end{array}$ & 361351 & 943320 & -- & ADPCE & Springfield & $1972-76$ & 10 \\
\hline 37 & $\begin{array}{l}\text { Flint Creek north of } \\
\text { Siloam Springs, Ark. }\end{array}$ & 361353 & 943320 & -- & ADPCE & Springfield & $1972-81$ & 15 \\
\hline 38 & $\begin{array}{l}\text { Crooked Creek at } \\
\text { Harrison, Ark. }\end{array}$ & 361357 & 930528 & -- & USGS & Springfield & 1984 & 1 \\
\hline 39 & $\begin{array}{l}\text { Crooked Creek above } \\
\text { Harrison, Ark. }\end{array}$ & 361404 & 930527 & -- & ADPCE & Salem & 1984 & 1 \\
\hline 40 & $\begin{array}{l}\text { Crooked Creek near } \\
\text { Harrison, Ark. }\end{array}$ & 361438 & 930438 & -- & USGS & Springfield & 1984,85 & 2 \\
\hline 41 & $\begin{array}{l}\text { Crooked Creek below } \\
\text { Harrison, Ark. }\end{array}$ & 361439 & 930439 & -- & ADPCE & Salem & 1984,85 & 2 \\
\hline 42 & $\begin{array}{l}\text { Eleven Point River near } \\
\text { Pocahontas, Ark. }\end{array}$ & 361443 & 910505 & 1,192 & ADPCE & Salem & 1974-84 & 19 \\
\hline 43 & $\begin{array}{l}\text { Crooked Creek at } \\
\text { Pyatt, Ark. }\end{array}$ & 361445 & 925004 & 207 & ADPCE & Springfield & 1974-78 & 10 \\
\hline 44 & $\begin{array}{l}\text { Pryor Creek at Highway } \\
69 \text { a Bridge, Okla. }\end{array}$ & 361455 & 951530 & -- & ODEQ & Osage Plains & 1980,90 & 2 \\
\hline
\end{tabular}


Table 5. Site and basin characteristics of surface-water sampling sites--Continued

$\left[\mathrm{mi}^{2}\right.$, square mile; WY70-90, water years 1970-1990; --, data unavailable; ODEQ, Oklahoma Department of Environmental Quality; ADPCE, Arkansas Department of Pollution Control and Ecology; USGS, U.S. Geological Survey; USEPA, U.S. Environmental Protection Agency; KDHE, Kansas Department of Health and Environment; USCOE, U.S. Army Corps of Engineers]

\begin{tabular}{|c|c|c|c|c|c|c|c|c|}
\hline $\begin{array}{c}\text { Site } \\
\text { number }\end{array}$ & Site name & Latitude & Longitude & $\begin{array}{c}\text { Drainage } \\
\text { area } \\
\left(\mathbf{m i}^{2}\right)\end{array}$ & $\begin{array}{c}\text { Collecting } \\
\text { agency }\end{array}$ & Physiographic area ${ }^{1}$ & $\begin{array}{c}\text { Period of } \\
\text { record } \\
(\text { WY70-90) }\end{array}$ & $\begin{array}{c}\text { Number } \\
\text { of } \\
\text { samples }\end{array}$ \\
\hline 45 & $\begin{array}{l}\text { Black River at } \\
\text { Pocahontas, Ark. }\end{array}$ & 361514 & 905812 & 4,845 & ADPCE & $\begin{array}{l}\text { Mississippi Alluvial Plain, } \\
\text { Salem, St. Francois }\end{array}$ & $1977-84$ & 11 \\
\hline 46 & $\begin{array}{l}\text { Hicks Creek near } \\
\text { Mountain Home, Ark. }\end{array}$ & 361732 & 922234 & -- & ADPCE & Salem & $1983-85$ & 5 \\
\hline 47 & $\begin{array}{l}\text { Current River near } \\
\text { Pocahontas, Ark. }\end{array}$ & 361755 & 905130 & 2,606 & ADPCE & $\begin{array}{l}\text { Mississippi Alluvial Plain, } \\
\text { Salem }\end{array}$ & $1972-84$ & 27 \\
\hline 48 & $\begin{array}{l}\text { Spavinaw Creek near } \\
\text { Sycamore, Okla. }\end{array}$ & 362007 & 943824 & 133 & USGS & Springfield & $1974-75$ & 4 \\
\hline 49 & $\begin{array}{l}\text { Spring River near } \\
\text { Hardy, Ark. }\end{array}$ & 362017 & 913030 & -- & ADPCE & Salem & $1974-82$ & 17 \\
\hline 50 & $\begin{array}{l}\text { Spavinaw Creek near } \\
\text { Cherokee City, Ark. }\end{array}$ & 362031 & 943515 & -- & ADPCE & Springfield & $1977-85$ & 13 \\
\hline 51 & $\begin{array}{l}\text { Eleven Point River near } \\
\text { Ravenden Springs, Ark. }\end{array}$ & 362048 & 910648 & 1,134 & ADPCE & Salem & $1972-73$ & 5 \\
\hline 52 & $\begin{array}{l}\text { Osage Creek above } \\
\text { Berryville, Ark. }\end{array}$ & 362056 & 933525 & -- & ADPCE & $\begin{array}{l}\text { Salem, Springfield, Bos- } \\
\text { ton }\end{array}$ & 1984,85 & 2 \\
\hline 53 & $\begin{array}{l}\text { South Fork Spring River } \\
\text { at Saddle, Ark. }\end{array}$ & 362100 & 913800 & -- & ADPCE & Salem & $1974-85$ & 19 \\
\hline 54 & $\begin{array}{l}\text { Osage Creek below } \\
\text { Berryville, Ark. }\end{array}$ & 362151 & 933626 & -- & ADPCE & $\begin{array}{l}\text { Salem, Springfield, Bos- } \\
\text { ton }\end{array}$ & 1984,85 & 4 \\
\hline 55 & $\begin{array}{l}\text { White River at Bull Shoals } \\
\text { Dam near Flippin, Ark. }\end{array}$ & 362154 & 923430 & 6,051 & USGS & $\begin{array}{l}\text { Salem, Boston, Spring- } \\
\text { field }\end{array}$ & $1974-82$ & 26 \\
\hline 56 & $\begin{array}{l}\text { Black River near Corning, } \\
\text { Ark. }\end{array}$ & 362407 & 903229 & 1,749 & ADPCE & $\begin{array}{l}\text { Mississippi Alluvial Plain, } \\
\text { Salem, St. Francois }\end{array}$ & $1972-86$ & 29 \\
\hline 57 & $\begin{array}{l}\text { Mckisic Creek tributary near } \\
\text { Bentonville, Ark. }\end{array}$ & 362426 & 941246 & -- & USGS & Springfield & 1984,85 & 2 \\
\hline 58 & $\begin{array}{l}\text { White River at Beaver Dam } \\
\text { near Eureka Springs, Ark. }\end{array}$ & 362515 & 935050 & 1,192 & ADPCE & $\begin{array}{l}\text { Salem, Boston, Spring- } \\
\text { field }\end{array}$ & $1973-74$ & 4 \\
\hline 59 & $\begin{array}{l}\text { Kings River near Berryville, } \\
\text { Ark. }\end{array}$ & 362536 & 933715 & 527 & ADPCE & $\begin{array}{l}\text { Salem, Boston, Spring- } \\
\text { field }\end{array}$ & $1973-85$ & 20 \\
\hline 60 & Long Creek near Denver, Ark. & 362546 & 931822 & -- & ADPCE & Springfield & 1984,85 & 2 \\
\hline 61 & $\begin{array}{l}\text { Neosho River near Langley, } \\
\text { Okla. }\end{array}$ & 362615 & 950244 & -- & ODEQ & Springfield, Osage Plains & 1990 & 1 \\
\hline 62 & $\begin{array}{l}\text { South Fork of Spring River } \\
\text { near Moko, Ark. }\end{array}$ & 362623 & 914944 & -- & USGS & Salem & $1972-73$ & 3 \\
\hline 63 & $\begin{array}{l}\text { South Fork of Spring River } \\
\text { near Salem, Ark. }\end{array}$ & 362623 & 914944 & -- & ADPCE & Salem & 1973 & 3 \\
\hline 64 & White River at Beaver, Ark. & 362820 & 934555 & 1,238 & USGS & $\begin{array}{l}\text { Salem, Boston, Spring- } \\
\text { field }\end{array}$ & $1974-82$ & 10 \\
\hline 65 & White River near Beaver, Ark. & 362828 & 934554 & -- & ADPCE & $\begin{array}{l}\text { Salem, Boston, Spring- } \\
\text { field }\end{array}$ & $1974-82$ & 12 \\
\hline 66 & Spring River near Thayer, Mo. & 363010 & 913131 & -- & ADPCE & Salem & $1972-85$ & 19 \\
\hline 67 & $\begin{array}{l}\text { Little Sugar Creek at Caverna, } \\
\text { Mo. }\end{array}$ & 363010 & 941630 & -- & ADPCE & Springfield & $1973-82$ & 17 \\
\hline
\end{tabular}


Table 5. Site and basin characteristics of surface-water sampling sites--Continued

$\left[\mathrm{mi}^{2}\right.$, square mile; WY70-90, water years 1970-1990; --, data unavailable; ODEQ, Oklahoma Department of Environmental Quality; ADPCE, Arkansas Department of Pollution Control and Ecology; USGS, U.S. Geological Survey; USEPA, U.S. Environmental Protection Agency; KDHE, Kansas Department of Health and Environment; USCOE, U.S. Army Corps of Engineers]

\begin{tabular}{|c|c|c|c|c|c|c|c|c|}
\hline $\begin{array}{c}\text { Site } \\
\text { number }\end{array}$ & Site name & Latitude & Longitude & $\begin{array}{c}\text { Drainage } \\
\text { area } \\
\left(\mathbf{m i}^{2}\right)\end{array}$ & $\begin{array}{c}\text { Collecting } \\
\text { agency }\end{array}$ & Physiographic area ${ }^{1}$ & $\begin{array}{c}\text { Period of } \\
\text { record } \\
(\text { WY70-90) }\end{array}$ & $\begin{array}{c}\text { Number } \\
\text { of } \\
\text { samples }\end{array}$ \\
\hline 68 & $\begin{array}{l}\text { Butler Creek near } \\
\text { Sulphur Springs, Ark. }\end{array}$ & 363044 & 942854 & -- & ADPCE & Springfield & $1973-85$ & 24 \\
\hline 69 & Myatt Creek near Lanton, Mo. & 363104 & 914418 & -- & USGS & Salem & $1972-73$ & 5 \\
\hline 70 & $\begin{array}{l}\text { Current River below Hawes } \\
\text { Campground, Mo. }\end{array}$ & 364908 & 905648 & -- & USGS & Salem & $1973-80$ & 6 \\
\hline 71 & $\begin{array}{l}\text { Neosho River near } \\
\text { Commerce, Okla. }\end{array}$ & 365543 & 945726 & -- & ODEQ & Osage Plains & 1990 & 1 \\
\hline 72 & Spring River near Verona, Mo. & 365600 & 934600 & -- & USEPA & Springfield & 1978 & 1 \\
\hline 73 & $\begin{array}{l}\text { Spring River at Devil's } \\
\text { Prominade Bridge, Okla. }\end{array}$ & 365604 & 944445 & -- & ODEQ & Osage, Springfield & $1981-90$ & 3 \\
\hline 74 & $\begin{array}{l}\text { Spring River } 0.6 \text { mi upstream } \\
\text { from U.S. } 60 \text { Bridge, Mo. }\end{array}$ & 365628 & 934656 & -- & USEPA & Springfield & 1981 & 1 \\
\hline 75 & $\begin{array}{l}\text { Unnamed Creek between } \\
\text { Syntex and Spring, Mo. }\end{array}$ & 365808 & 934757 & -- & USEPA & Springfield & 1981 & 1 \\
\hline 76 & $\begin{array}{l}\text { Spring River west of Verona, } \\
\text { Mo. }\end{array}$ & 365808 & 934803 & -- & USEPA & Springfield & 1981 & 1 \\
\hline 77 & $\begin{array}{l}\text { Douger Brook at State } \\
\text { Route P Bridge, Mo. }\end{array}$ & 365830 & 934741 & -- & USEPA & Springfield & 1981 & 1 \\
\hline 78 & $\begin{array}{l}\text { Spring River } 2.4 \text { mi down } \\
\text { stream of Douger Bridge, Mo. }\end{array}$ & 365951 & 934859 & -- & USEPA & Springfield & 1981 & 1 \\
\hline 79 & $\begin{array}{l}\text { James River near Boaz below } \\
\text { Wilson Creek, Mo. }\end{array}$ & 370025 & 932150 & 462 & USEPA & Springfield & 1978 & 1 \\
\hline 80 & $\begin{array}{l}\text { Spring River at Baxter } \\
\text { Springs, Kans. }\end{array}$ & 370105 & 944314 & -- & USEPA & Springfield & 1982 & 1 \\
\hline 81 & $\begin{array}{l}\text { Spring River near Baxter } \\
\text { Springs, Kans. }\end{array}$ & 370125 & 944315 & 2,510 & USGS & Springfield & $1972-73$ & 4 \\
\hline 82 & $\begin{array}{l}\text { Neosho River at Chetopa, } \\
\text { Kans. }\end{array}$ & 370210 & 950450 & -- & KDHE & Osage Plains & $1972-89$ & 33 \\
\hline 83 & $\begin{array}{l}\text { Shoal Creek near Galena, } \\
\text { Kans. }\end{array}$ & 370231 & 943834 & -- & KDHE & Springfield & $1975-90$ & 18 \\
\hline 84 & $\begin{array}{l}\text { Neosho River near Chetopa, } \\
\text { Kans. }\end{array}$ & 370309 & 950551 & -- & KDHE & Osage Plains & 1976 & 1 \\
\hline 85 & $\begin{array}{l}\text { Labette Creek near Chetopa, } \\
\text { Kans. }\end{array}$ & 370428 & 950611 & -- & KDHE & Osage Plains & 1990 & 2 \\
\hline 86 & $\begin{array}{l}\text { James River } 2 \text { mi above } \\
\text { Wilson Creek, Mo. }\end{array}$ & 370435 & 932215 & -- & USEPA & Springfield & 1978 & 1 \\
\hline 87 & $\begin{array}{l}\text { Short Creek near Galena, } \\
\text { Kans. }\end{array}$ & 370523 & 943958 & -- & KDHE & Springfield & 1990 & 1 \\
\hline 88 & Jones Creek near Fidelity, Mo. & 370549 & 941711 & -- & USGS & Springfield & $1977-78$ & 4 \\
\hline 89 & $\begin{array}{l}\text { Wilson Creek downstream of } \\
\text { South Creek, Mo. }\end{array}$ & 370624 & 932430 & -- & USEPA & Springfield & 1985 & 1 \\
\hline 90 & $\begin{array}{l}\text { Center Creek above } \\
\text { Fidelity, Mo. }\end{array}$ & 370707 & 941528 & -- & USGS & Springfield & 1978 & 6 \\
\hline
\end{tabular}


Table 5. Site and basin characteristics of surface-water sampling sites--Continued

$\left[\mathrm{mi}^{2}\right.$, square mile; WY70-90, water years 1970-1990; --, data unavailable; ODEQ, Oklahoma Department of Environmental Quality; ADPCE, Arkansas Department of Pollution Control and Ecology; USGS, U.S. Geological Survey; USEPA, U.S. Environmental Protection Agency; KDHE, Kansas Department of Health and Environment; USCOE, U.S. Army Corps of Engineers]

\begin{tabular}{|c|c|c|c|c|c|c|c|c|}
\hline $\begin{array}{c}\text { Site } \\
\text { number }\end{array}$ & Site name & Latitude & Longitude & $\begin{array}{c}\text { Drainage } \\
\text { area } \\
\left(\mathbf{m i}^{2}\right)\end{array}$ & $\begin{array}{c}\text { Collecting } \\
\text { agency }\end{array}$ & Physiographic area ${ }^{1}$ & $\begin{array}{c}\text { Period of } \\
\text { record } \\
(\text { WY70-90) }\end{array}$ & $\begin{array}{c}\text { Number } \\
\text { of } \\
\text { samples }\end{array}$ \\
\hline 91 & Turkey Creek near Joplin, Mo. & 370715 & 943455 & 42 & KDHE & Springfield & $1975-90$ & 18 \\
\hline 92 & $\begin{array}{l}\text { Center Creek near Carterville, } \\
\text { Mo. }\end{array}$ & 370826 & 942257 & 232 & USGS & Springfield & $1977-78$ & 7 \\
\hline 93 & $\begin{array}{l}\text { Shawnee Creek near Crestline, } \\
\text { Kans. }\end{array}$ & 370855 & 944038 & -- & KDHE & Springfield, Osage Plains & 1990 & 1 \\
\hline 94 & $\begin{array}{l}\text { Center Creek near } \\
\text { Smithfield, Mo. }\end{array}$ & 370921 & 943610 & -- & KDHE & Springfield & $1975-90$ & 17 \\
\hline 95 & $\begin{array}{l}\text { Center Creek south of } \\
\text { Smithfield, Mo. }\end{array}$ & 370930 & 943615 & -- & USEPA & Springfield & 1977 & 1 \\
\hline 96 & $\begin{array}{l}\text { Neosho River near } \\
\text { Oswego, Kans. }\end{array}$ & 370954 & 950346 & -- & KDHE & Osage Plains & 1990 & 2 \\
\hline 97 & $\begin{array}{l}\text { Wilson Creek upstream of } \\
\text { South Creek, Mo. }{ }^{3}\end{array}$ & 371006 & 932212 & -- & USEPA & Springfield & 1985 & 1 \\
\hline 98 & $\begin{array}{l}\text { Current River above } \\
\text { Powder Mill, Mo. }\end{array}$ & 371032 & 911248 & -- & USGS & Salem & $1973-80$ & 6 \\
\hline 99 & $\begin{array}{l}\text { Spring River near Crestline, } \\
\text { Kans. }\end{array}$ & 371044 & 943830 & -- & KDHE & Springfield & 1990 & 1 \\
\hline 100 & $\begin{array}{l}\text { Jacks Fork above } \\
\text { Two Rivers, Mo. }\end{array}$ & 371053 & 911736 & -- & USGS & Salem & $1973-80$ & 6 \\
\hline 101 & $\begin{array}{l}\text { Spring River near Galena, } \\
\text { Kans. }\end{array}$ & 371125 & 943805 & -- & USEPA & Springfield & 1977 & 1 \\
\hline 102 & $\begin{array}{l}\text { Spring River south of } \\
\text { Waco, Mo. }\end{array}$ & 371315 & 943615 & -- & USEPA & Springfield & 1977 & 1 \\
\hline 103 & $\begin{array}{l}\text { Cow Creek near } \\
\text { Lawton, Kans. }\end{array}$ & 371321 & 943914 & -- & KDHE & Osage Plains & 1990 & 1 \\
\hline 104 & $\begin{array}{l}\text { Labette Creek near } \\
\text { Labette, Kans. }\end{array}$ & 371348 & 951152 & -- & KDHE & Osage Plains & 1990 & 2 \\
\hline 105 & $\begin{array}{l}\text { Lightning Creek near } \\
\text { Oswego, Kans. }\end{array}$ & 371418 & 950238 & -- & KDHE & Osage Plains & 1990 & 2 \\
\hline 106 & $\begin{array}{l}\text { Spring River near } \\
\text { Waco, Mo. }\end{array}$ & 371444 & 943358 & 1,164 & KDHE & Springfield, Osage Plains & $1973-89$ & 32 \\
\hline 107 & $\begin{array}{l}\text { Current River below } \\
\text { Montauk State Park, Mo. }\end{array}$ & 372701 & 912941 & -- & USGS & Salem & $1973-80$ & 7 \\
\hline 108 & $\begin{array}{l}\text { Neosho River water } \\
\text { station no. } 1 \text {, Kans. }\end{array}$ & 372918 & 950830 & -- & KDHE & Osage Plains & 1990 & 1 \\
\hline 109 & $\begin{array}{l}\text { Marmaton River near Fort } \\
\text { Scott, Kans. }\end{array}$ & 375113 & 944649 & -- & KDHE & Osage Plains & $1975-90$ & 18 \\
\hline 110 & $\begin{array}{l}\text { Devil's Elbow on } \\
\text { Big Piney, Mo. }\end{array}$ & 375115 & 920400 & -- & USEPA & Salem & 1977 & 1 \\
\hline 111 & $\begin{array}{l}\text { Gasconade at Highway Y, } \\
\text { Mo. }\end{array}$ & 375400 & 920800 & -- & USEPA & Salem & 1977 & 1 \\
\hline 112 & $\begin{array}{l}\text { Marmaton River near } \\
\text { Nevada, Mo. }\end{array}$ & 375507 & 942139 & -- & USGS & Osage Plains & 1990 & 1 \\
\hline
\end{tabular}


Table 5. Site and basin characteristics of surface-water sampling sites--Continued

$\left[\mathrm{mi}^{2}\right.$, square mile; WY70-90, water years 1970-1990; --, data unavailable; ODEQ, Oklahoma Department of Environmental Quality; ADPCE, Arkansas Department of Pollution Control and Ecology; USGS, U.S. Geological Survey; USEPA, U.S. Environmental Protection Agency; KDHE, Kansas Department of Health and Environment; USCOE, U.S. Army Corps of Engineers]

\begin{tabular}{|c|c|c|c|c|c|c|c|c|}
\hline $\begin{array}{c}\text { Site } \\
\text { number }\end{array}$ & Site name & Latitude & Longitude & $\begin{array}{l}\text { Drainage } \\
\text { area } \\
\left(\mathbf{m i}^{2}\right)\end{array}$ & $\begin{array}{c}\text { Collecting } \\
\text { agency }\end{array}$ & Physiographic area ${ }^{1}$ & $\begin{array}{l}\text { Period of } \\
\text { record } \\
(\text { WY70-90) }\end{array}$ & $\begin{array}{c}\text { Number } \\
\text { of } \\
\text { samples }\end{array}$ \\
\hline 113 & $\begin{array}{l}\text { Gasconade River near } \\
\text { Jerome, Mo. }\end{array}$ & 375512 & 915833 & -- & USEPA & Salem & 1977 & 1 \\
\hline 114 & $\begin{array}{l}\text { Little Osage River near } \\
\text { Horton, Mo. }\end{array}$ & 375938 & 942207 & -- & USGS & Osage Plains & 1990 & 1 \\
\hline 115 & $\begin{array}{l}\text { Little Osage River near } \\
\text { Fulton, Kans. }\end{array}$ & 380029 & 944142 & -- & KDHE & Osage Plains & $1975-90$ & 18 \\
\hline 116 & $\begin{array}{l}\text { Little Osage River at } \\
\text { Fulton, Kans. }\end{array}$ & 380109 & 944248 & 295 & USGS & Osage Plains & 1980,81 & 2 \\
\hline 117 & $\begin{array}{l}\text { Osage River above } \\
\text { Schell City, Mo. }\end{array}$ & 380320 & 940844 & 5,410 & USGS & Osage Plains & 1990 & 1 \\
\hline 118 & $\begin{array}{l}\text { Marais des Cygnes } \\
\text { drainage ditch, Mo. }\end{array}$ & 380802 & 942102 & -- & USGS & Osage Plains & 1990 & 1 \\
\hline 119 & $\begin{array}{l}\text { Miami Creek near } \\
\text { Butler, Mo. }\end{array}$ & 381039 & 942112 & -- & USGS & Osage Plains & 1990 & 1 \\
\hline 120 & $\begin{array}{l}\text { Osage Gasconade, } \\
\text { Bagnell Dam, Mo. }\end{array}$ & 381220 & 923745 & -- & USEPA & Salem & $1970-71$ & 3 \\
\hline 121 & $\begin{array}{l}\text { Meramec River at } \\
\text { Meramec Park, Mo. }\end{array}$ & 381400 & 910500 & -- & USEPA & Salem & 1977 & 1 \\
\hline 122 & Calvey Creek no. 1, Mo. & 382200 & 904400 & -- & USEPA & Salem & 1977 & 1 \\
\hline 123 & $\begin{array}{l}\text { Tebo Creek, Henry Co. } \\
\text { Highway PP, Mo. }\end{array}$ & 382204 & 933240 & -- & USCOE & Springfield, Osage Plains & 1988 & 2 \\
\hline 124 & Calvey Creek no. 2, Mo. & 382300 & 904600 & -- & USEPA & Salem & 1977 & 1 \\
\hline 125 & Calvey Creek no. 3, Mo. & 382350 & 904610 & -- & USEPA & Salem & 1977 & 1 \\
\hline 126 & $\begin{array}{l}\text { Meramec River at Highway } \\
21 \text { Bridge, Mo. }\end{array}$ & 382745 & 902500 & -- & USEPA & Salem & 1983 & 2 \\
\hline 127 & $\begin{array}{l}\text { Romaine Creek near } \\
\text { mouth, Mo. }\end{array}$ & 382748 & 902527 & -- & USEPA & Salem & 1983 & 3 \\
\hline 128 & $\begin{array}{l}\text { Sugar Creek near } \\
\text { mouth, Mo. }\end{array}$ & 382813 & 902543 & -- & USEPA & Salem & 1983 & 3 \\
\hline 129 & $\begin{array}{l}\text { Saline Creek before } \\
\text { confluence of Sugar Creek, } \\
\text { Mo. }\end{array}$ & 382825 & 902549 & -- & USEPA & Salem & 1983 & 3 \\
\hline 130 & $\begin{array}{l}\text { Meramec River upstream I44 } \\
\text { Bridge at Times Beach, Mo. }\end{array}$ & 383013 & 903525 & -- & USEPA & Salem & 1983 & 3 \\
\hline 131 & $\begin{array}{l}\text { Meramec River below Fenton } \\
\text { upstream of Marina, Mo. }\end{array}$ & 383030 & 902610 & -- & USEPA & Salem & 1983 & 3 \\
\hline 132 & $\begin{array}{l}\text { Meramec River downstream } \\
\text { of Glencoe, Mo. }\end{array}$ & 383232 & 903507 & -- & USEPA & Salem & 1983 & 3 \\
\hline 133 & $\begin{array}{l}\text { Meramec River upstream of } \\
\text { Valley Park Bridge, Mo. }\end{array}$ & 383240 & 903030 & -- & USEPA & Salem & 1983 & 3 \\
\hline 134 & $\begin{array}{l}\text { Chrysler car plant-industrial } \\
\text { waste, Mo. }\end{array}$ & 383300 & 902735 & -- & USEPA & Salem & 1983 & 2 \\
\hline 135 & $\begin{array}{l}\text { Fishpot Creek at Hanna Road } \\
\text { Bridge, St. Louis, Mo. }\end{array}$ & 383308 & 903041 & -- & USEPA & Salem & 1983 & 3 \\
\hline
\end{tabular}


Table 5. Site and basin characteristics of surface-water sampling sites--Continued

$\left[\mathrm{mi}^{2}\right.$, square mile; WY70-90, water years 1970-1990; --, data unavailable; ODEQ, Oklahoma Department of Environmental Quality; ADPCE, Arkansas Department of Pollution Control and Ecology; USGS, U.S. Geological Survey; USEPA, U.S. Environmental Protection Agency; KDHE, Kansas Department of Health and Environment; USCOE, U.S. Army Corps of Engineers]

\begin{tabular}{|c|c|c|c|c|c|c|c|c|}
\hline $\begin{array}{c}\text { Site } \\
\text { number }\end{array}$ & Site name & Latitude & Longitude & $\begin{array}{l}\text { Drainage } \\
\text { area } \\
\left(\mathbf{m i}^{2}\right)\end{array}$ & $\begin{array}{c}\text { Collecting } \\
\text { agency }\end{array}$ & Physiographic area ${ }^{1}$ & $\begin{array}{c}\text { Period of } \\
\text { record } \\
(\text { WY70-90) }\end{array}$ & $\begin{array}{l}\text { Number } \\
\text { of } \\
\text { samples }\end{array}$ \\
\hline 136 & $\begin{array}{l}\text { Grand Glaize Creek at } \\
\text { Marshall Road Bridge, Mo. }\end{array}$ & 383316 & 902751 & -- & USEPA & Salem & 1983 & 3 \\
\hline 137 & $\begin{array}{l}\text { Meramec River near } \\
\text { Kirkwood wastewater- } \\
\text { treatment intake, Mo. }\end{array}$ & 383334 & 902645 & -- & USEPA & Salem & 1983 & 3 \\
\hline 138 & $\begin{array}{l}\text { Grand Glaize Creek at } \\
\text { Carmen Road Bridge, Mo. }\end{array}$ & 383430 & 902814 & -- & USEPA & Salem & 1983 & 3 \\
\hline 139 & $\begin{array}{l}\text { Sugar Creek near Ozark } \\
\text { View Subdivision, } \\
\text { St. Louis, Mo. }\end{array}$ & 383447 & 902732 & -- & USEPA & Salem & 1983 & 3 \\
\hline 140 & $\begin{array}{l}\text { Grand Glaize Creek Below } \\
\text { Sulphur Springs Road, Mo. }\end{array}$ & 383533 & 903108 & -- & USEPA & Salem & 1983 & 3 \\
\hline
\end{tabular}

${ }^{1}$ Springfield, Springfield Plateau; Boston, Boston Mountains; Salem, Salem Plateau; St. Francois, St. Francois Mountains.

${ }^{2}$ Original site name is "Wilson Creek downstream"; reference to South Creek added for clarification.

${ }^{3}$ Original site name is "Wilson Creek upstream"; reference to South Creek added for clarification. 
Table 6. Site characteristics of ground-water sampling sites

[WY70-90, water years 1970-90; USGS, U.S. Geological Survey; Coop, cooperative program; MODOH, Missouri Department of Health; OZAQ, Ozark aquifer; ALVM, Post Paleozoic sediments; SPAQ, Springfield Plateau aquifer; WIPC, Western Interior Plains confining system; --, data unavailable]

\begin{tabular}{|c|c|c|c|c|c|c|c|c|}
\hline $\begin{array}{c}\text { Site } \\
\text { number }\end{array}$ & $\begin{array}{c}\text { Local number/ } \\
\text { name }\end{array}$ & Latitude & Longitude & $\begin{array}{c}\text { Collecting } \\
\text { agency }\end{array}$ & $\begin{array}{l}\text { Hydro- } \\
\text { geologic } \\
\text { unit }\end{array}$ & $\begin{array}{c}\text { Well } \\
\text { depth } \\
\text { (feet) }\end{array}$ & $\begin{array}{c}\text { Period of } \\
\text { record } \\
(\text { WY70-90) }\end{array}$ & $\begin{array}{c}\text { Number } \\
\text { of } \\
\text { samples }\end{array}$ \\
\hline 1 & T20N R08W 27AAB 1 & 362219 & 0914921 & USGS & OZAQ & 1,280 & 1975 & 1 \\
\hline 2 & T20N R09W 18CAD1 & 362338 & 0915904 & USGS & OZAQ & 1,250 & 1975 & 1 \\
\hline 3 & T21N R03E 35BCC2 & 362515 & 0904347 & USGS & ALVM & 55 & 1990 & 1 \\
\hline 4 & T21N R29W 35DDB2 & 362636 & 0940126 & USGS & OZAQ & 1,769 & 1972,1977 & 2 \\
\hline 5 & T22N R05E 26BBC & 363151 & 0903010 & USGS & ALVM & 26 & 1987 & 1 \\
\hline 6 & T22N R06E 12DCC & 363344 & 0902157 & USGS & ALVM & 30 & $1986-87$ & 3 \\
\hline 7 & T23N R05E 34DCC & 363529 & 0903035 & USGS & ALVM & 25 & $1986-87$ & 3 \\
\hline 8 & T23N R07E 08DBB & 363916 & 0901924 & USGS & ALVM & 80 & 1987 & 1 \\
\hline 9 & T24N R08E 32CDC & 364032 & 0901311 & USGS & ALVM & 40 & 1987 & 2 \\
\hline 10 & T24N R06E 25CDD & 364137 & 0902156 & USGS & ALVM & 60 & 1987 & 1 \\
\hline 11 & T24N R06E 30BBA & 364228 & 0902722 & USGS & ALVM & 65 & 1987 & 1 \\
\hline 12 & T24N R08E 23BCC & 364240 & 0901019 & USGS & ALVM & 50 & 1987 & 1 \\
\hline 13 & T24N R07E 22BBB1 & 364311 & 0901754 & USGS & ALVM & -- & $1986-87$ & 3 \\
\hline 14 & T25N R08E 18ADD1 & 364848 & 0901338 & USGS & ALVM & 48 & $1986-87$ & 3 \\
\hline 15 & T35S R25E 04CCC01 & 370105 & 0944121 & USGS & SPAQ & 202 & 1978 & 1 \\
\hline 16 & T34S R24E 35DAB01 & 370218 & 0944453 & USGS & SPAQ & -- & 1988 & 1 \\
\hline 17 & T34S R24E 17DDC01 & 370437 & 0944755 & USGS & WIPC & 40 & 1988 & 1 \\
\hline 18 & T30S R20E 12DCC01 & 372634 & 0951002 & USGS & WIPC & 30 & 1981 & 1 \\
\hline 19 & T29S R25E 01ACB01 & 373308 & 0943720 & USGS & WIPC & -- & 1988 & 1 \\
\hline 20 & T28S R25E 03AAA01 & 373836 & 0943906 & USGS & WIPC & 11 & 1979 & 1 \\
\hline 21 & Well 4085 & 374036 & 0941314 & $\begin{array}{c}\text { USGS, } \\
\text { (Coop-MODOH) }\end{array}$ & WIPC & 22 & 1990 & 1 \\
\hline 22 & Well 4084 & 374046 & 0941256 & $\begin{array}{c}\text { USGS, } \\
\text { (Coop-MODOH) }\end{array}$ & WIPC & 24.9 & 1990 & 1 \\
\hline 23 & Spring 4604 & 374338 & 0940600 & $\begin{array}{c}\text { USGS, } \\
\text { (Coop-MODOH) }\end{array}$ & WIPC & -- & 1990 & 1 \\
\hline 24 & Well 4090 & 374508 & 0941249 & $\begin{array}{c}\text { USGS, } \\
\text { (Coop-MODOH) }\end{array}$ & WIPC & 25 & 1990 & 1 \\
\hline 25 & Spring 4069a & 374606 & 0942102 & $\begin{array}{c}\text { USGS, } \\
\text { (Coop-MODOH) }\end{array}$ & WIPC & -- & 1990 & 1 \\
\hline 26 & Well 4069 & 374609 & 0942102 & $\begin{array}{c}\text { USGS, } \\
\text { (Coop-MODOH) }\end{array}$ & WIPC & 33 & 1990 & 1 \\
\hline 27 & Well 4603 & 374704 & 0940659 & $\begin{array}{c}\text { USGS, } \\
\text { (Coop-MODOH) }\end{array}$ & WIPC & 29.6 & 1990 & 1 \\
\hline 28 & Well 4082 & 374713 & 0943304 & $\begin{array}{c}\text { USGS, } \\
\text { (Coop-MODOH) }\end{array}$ & WIPC & 22 & 1990 & 1 \\
\hline
\end{tabular}


Table 6. Site characteristics of ground-water sampling sites--Continued

[WY70-90, water years 1970-90; USGS, U.S. Geological Survey; Coop, cooperative program; MODOH, Missouri Department of Health; OZAQ, Ozark aquifer; ALVM, Post Paleozoic sediments; SPAQ, Springfield Plateau aquifer; WIPC, Western Interior Plains confining system; --, data unavailable]

\begin{tabular}{|c|c|c|c|c|c|c|c|c|}
\hline $\begin{array}{c}\text { Site } \\
\text { number }\end{array}$ & $\begin{array}{c}\text { Local number/ } \\
\text { name }\end{array}$ & Latitude & Longitude & $\begin{array}{c}\text { Collecting } \\
\text { agency }\end{array}$ & $\begin{array}{c}\text { Hydro- } \\
\text { geologic } \\
\text { unit }\end{array}$ & $\begin{array}{c}\text { Well } \\
\text { depth } \\
\text { (feet) }\end{array}$ & $\begin{array}{c}\text { Period of } \\
\text { record } \\
(\text { WY70-90) }\end{array}$ & $\begin{array}{c}\text { Number } \\
\text { of } \\
\text { samples }\end{array}$ \\
\hline 29 & Well 4075 & 375044 & 0943633 & $\begin{array}{c}\text { USGS, } \\
\text { (Coop-MODOH) }\end{array}$ & WIPC & 22 & 1990 & 1 \\
\hline 30 & Well 4060 & 375123 & 0943038 & $\begin{array}{c}\text { USGS, } \\
\text { (Coop-MODOH) }\end{array}$ & WIPC & 38.5 & 1990 & 1 \\
\hline 31 & Well 4071 & 375305 & 0942506 & $\begin{array}{c}\text { USGS, } \\
\text { (Coop-MODOH) }\end{array}$ & WIPC & 65 & 1990 & 1 \\
\hline 32 & Well 2060 & 375429 & 0934638 & $\begin{array}{c}\text { USGS, } \\
(\mathrm{Coop}-\mathrm{MODOH})\end{array}$ & WIPC & 10.8 & 1990 & 1 \\
\hline 33 & Well 4001 & 375633 & 0942949 & $\begin{array}{c}\text { USGS, } \\
\text { (Coop-MODOH) }\end{array}$ & WIPC & 34. & 1990 & 1 \\
\hline 34 & Well 4063 & 375645 & 0942347 & $\begin{array}{c}\text { USGS, } \\
(\mathrm{Coop}-\mathrm{MODOH})\end{array}$ & WIPC & 28.1 & 1990 & 1 \\
\hline 35 & Well 2117 & 375711 & 0935552 & $\begin{array}{c}\text { USGS, } \\
(\mathrm{Coop}-\mathrm{MODOH})\end{array}$ & SPAQ & 60 & 1990 & 1 \\
\hline 36 & Well 4087 & 375732 & 0940710 & $\begin{array}{c}\text { USGS, } \\
(\mathrm{Coop}-\mathrm{MODOH})\end{array}$ & WIPC & 18 & 1990 & 1 \\
\hline 37 & Well 4002 & 375733 & 0943419 & $\begin{array}{c}\text { USGS, } \\
\text { (Coop-MODOH) }\end{array}$ & WIPC & 21.41 & 1990 & 1 \\
\hline 38 & Well 4504 & 375804 & 0941901 & $\begin{array}{c}\text { USGS, } \\
\text { (Coop-MODOH) }\end{array}$ & WIPC & 23 & 1990 & 1 \\
\hline 39 & Well 2045 & 375809 & 0933957 & $\begin{array}{c}\text { USGS, } \\
\text { (Coop-MODOH) }\end{array}$ & WIPC & 50 & 1990 & 1 \\
\hline 40 & Well 4501 & 375828 & 0940454 & $\begin{array}{c}\text { USGS, } \\
(\mathrm{Coop}-\mathrm{MODOH})\end{array}$ & WIPC & 26 & 1990 & 1 \\
\hline 41 & Well 4061 & 375832 & 0942410 & $\begin{array}{c}\text { USGS, } \\
\text { (Coop-MODOH) }\end{array}$ & WIPC & 40.9 & 1990 & 1 \\
\hline 42 & Well 4506 & 375834 & 0942203 & $\begin{array}{c}\text { USGS, } \\
(\mathrm{Coop}-\mathrm{MODOH})\end{array}$ & WIPC & 90 & 1990 & 1 \\
\hline 43 & Well 4503 & 375838 & 0941514 & $\begin{array}{c}\text { USGS, } \\
\text { (Coop-MODOH) }\end{array}$ & WIPC & 15 & 1990 & 1 \\
\hline 44 & Well 4056 & 380104 & 0942335 & $\begin{array}{c}\text { USGS, } \\
\text { (Coop-MODOH) }\end{array}$ & WIPC & 33.6 & 1990 & 1 \\
\hline 45 & Well 4507 & 380120 & 0942015 & $\begin{array}{c}\text { USGS, } \\
\text { (Coop-MODOH) }\end{array}$ & WIPC & 20 & 1990 & 1 \\
\hline 46 & Well 4062 & 380122 & 0943033 & $\begin{array}{c}\text { USGS, } \\
(\mathrm{Coop}-\mathrm{MODOH})\end{array}$ & WIPC & 20 & 1990 & 1 \\
\hline 47 & Well 4505 & 380125 & 0942123 & $\begin{array}{c}\text { USGS, } \\
\text { (Coop-MODOH) }\end{array}$ & WIPC & 20.75 & 1990 & 1 \\
\hline 48 & Well 4502 & 380136 & 0941006 & $\begin{array}{c}\text { USGS, } \\
\text { (Coop-MODOH) }\end{array}$ & WIPC & 43 & 1990 & 1 \\
\hline 49 & Well 4508 & 380158 & 0941958 & $\begin{array}{c}\text { USGS, } \\
\text { (Coop-MODOH) }\end{array}$ & WIPC & 60.35 & 1990 & 1 \\
\hline
\end{tabular}


Table 6. Site characteristics of ground-water sampling sites--Continued

[WY70-90, water years 1970-90; USGS, U.S. Geological Survey; Coop, cooperative program; MODOH, Missouri Department of Health; OZAQ, Ozark aquifer; ALVM, Post Paleozoic sediments; SPAQ, Springfield Plateau aquifer; WIPC, Western Interior Plains confining system; --, data unavailable]

\begin{tabular}{|c|c|c|c|c|c|c|c|c|}
\hline $\begin{array}{c}\text { Site } \\
\text { number }\end{array}$ & $\begin{array}{c}\text { Local number/ } \\
\text { name }\end{array}$ & Latitude & Longitude & $\begin{array}{c}\text { Collecting } \\
\text { agency }\end{array}$ & $\begin{array}{c}\text { Hydro- } \\
\text { geologic } \\
\text { unit }\end{array}$ & $\begin{array}{r}\text { Well } \\
\text { depth } \\
\text { (feet) }\end{array}$ & $\begin{array}{c}\text { Period of } \\
\text { record } \\
(\text { WY70-90) }\end{array}$ & $\begin{array}{c}\text { Number } \\
\text { of } \\
\text { samples }\end{array}$ \\
\hline 50 & Well 4510 & 380203 & 0940800 & $\begin{array}{c}\text { USGS, } \\
\text { (Coop-MODOH) }\end{array}$ & WIPC & 240 & 1990 & 1 \\
\hline 51 & Well 4511 & 380210 & 0940759 & $\begin{array}{c}\text { USGS, } \\
\text { (Coop-MODOH) }\end{array}$ & WIPC & 55 & 1990 & 1 \\
\hline 52 & Well 4055 & 380222 & 0942649 & $\begin{array}{c}\text { USGS, } \\
\text { (Coop-MODOH) }\end{array}$ & WIPC & -- & 1990 & 1 \\
\hline 53 & Well 4509 & 380224 & 0941704 & $\begin{array}{c}\text { USGS, } \\
\text { (Coop-MODOH) }\end{array}$ & WIPC & 53.17 & 1990 & 1 \\
\hline 54 & Well 2023 & 380237 & 0940052 & $\begin{array}{c}\text { USGS, } \\
\text { (Coop-MODOH) }\end{array}$ & WIPC & 69.5 & 1990 & 1 \\
\hline 55 & Well 2002 & 380253 & 0940251 & $\begin{array}{c}\text { USGS, } \\
\text { (Coop-MODOH) }\end{array}$ & WIPC & 16.45 & 1990 & 1 \\
\hline 56 & Well 1181 & 380330 & 0941722 & $\begin{array}{c}\text { USGS, } \\
\text { (Coop-MODOH) }\end{array}$ & WIPC & 32 & 1990 & 1 \\
\hline 57 & 23S 25E 07DAA 01 & 380335 & 0944147 & USGS & WIPC & 19.4 & 1979 & 1 \\
\hline 58 & Well 2075 & 380404 & 0935616 & $\begin{array}{c}\text { USGS, } \\
\text { (Coop-MODOH) }\end{array}$ & WIPC & 165 & 1990 & 1 \\
\hline 59 & Well 1906 & 380442 & 0940929 & $\begin{array}{c}\text { USGS, } \\
\text { (Coop-MODOH) }\end{array}$ & WIPC & 28.4 & 1990 & 1 \\
\hline 60 & Well 2805 & 380445 & 0935142 & $\begin{array}{c}\text { USGS, } \\
\text { (Coop-MODOH) }\end{array}$ & WIPC & 128 & 1990 & 1 \\
\hline 61 & 23S 25E 04BBC 01 & 380448 & 0944033 & USGS & -- & 38.4 & 1989 & 1 \\
\hline 62 & 23S 25E 04BBC 02 & 380448 & 0944033 & USGS & WIPC & 28.7 & 1989 & 1 \\
\hline 63 & 23S 25E 04BBB 01 & 380454 & 0944034 & USGS & -- & 32.7 & 1989 & 1 \\
\hline 64 & 23S 25E 04BBB 02 & 380454 & 0944034 & USGS & -- & 40.4 & 1989 & 1 \\
\hline 65 & 23S 25E 04BBB 03 & 380454 & 0944034 & USGS & -- & 32.7 & 1989 & 1 \\
\hline 66 & $22 \mathrm{~S} 25 \mathrm{E} 33 \mathrm{CCD} 01$ & 380501 & 0944025 & USGS & -- & 49.5 & 1989 & 1 \\
\hline 67 & $22 \mathrm{~S} 25 \mathrm{E} 33 \mathrm{CCD} 02$ & 380501 & 0944025 & USGS & -- & 40.6 & 1989 & 1 \\
\hline 68 & $22 \mathrm{~S} 25 \mathrm{E} 33 \mathrm{CCD} 03$ & 380501 & 0944025 & USGS & WIPC & 8.7 & 1989 & 2 \\
\hline 69 & $22 \mathrm{~S} 25 \mathrm{E} 33 \mathrm{CCC} 01$ & 380501 & 0944034 & USGS & -- & 42.2 & 1989 & 1 \\
\hline 70 & $22 \mathrm{~S} 25 \mathrm{E} 33 \mathrm{CCC} 02$ & 380501 & 0944034 & USGS & -- & 30.4 & 1989 & 1 \\
\hline 71 & Well 2802 & 380521 & 0940046 & $\begin{array}{c}\text { USGS, } \\
\text { (Coop-MODOH) }\end{array}$ & WIPC & 225 & 1990 & 1 \\
\hline 72 & Well 1907 & 380528 & 0941007 & $\begin{array}{c}\text { USGS, } \\
\text { (Coop-MODOH) }\end{array}$ & WIPC & 16.9 & 1990 & 1 \\
\hline 73 & Well 1902 & 380540 & 0941749 & $\begin{array}{c}\text { USGS, } \\
\text { (Coop-MODOH) }\end{array}$ & ALVM & 88 & 1990 & 1 \\
\hline 74 & Well 1133 & 380609 & 0942625 & $\begin{array}{c}\text { USGS, } \\
\text { (Coop-MODOH) }\end{array}$ & WIPC & 200 & 1990 & 1 \\
\hline
\end{tabular}


Table 6. Site characteristics of ground-water sampling sites--Continued

[WY70-90, water years 1970-90; USGS, U.S. Geological Survey; Coop, cooperative program; MODOH, Missouri Department of Health; OZAQ, Ozark aquifer; ALVM, Post Paleozoic sediments; SPAQ, Springfield Plateau aquifer; WIPC, Western Interior Plains confining system; --, data unavailable]

\begin{tabular}{|c|c|c|c|c|c|c|c|c|}
\hline $\begin{array}{c}\text { Site } \\
\text { number }\end{array}$ & $\begin{array}{c}\text { Local number/ } \\
\text { name }\end{array}$ & Latitude & Longitude & $\begin{array}{c}\text { Collecting } \\
\text { agency }\end{array}$ & $\begin{array}{c}\text { Hydro- } \\
\text { geologic } \\
\text { unit }\end{array}$ & $\begin{array}{c}\text { Well } \\
\text { depth } \\
\text { (feet) }\end{array}$ & $\begin{array}{c}\text { Period of } \\
\text { record } \\
(\text { WY70-90) }\end{array}$ & $\begin{array}{c}\text { Number } \\
\text { of } \\
\text { samples }\end{array}$ \\
\hline 75 & Well 1179 & 380615 & 0941640 & $\begin{array}{c}\text { USGS, } \\
\text { (Coop-MODOH) }\end{array}$ & WIPC & 43 & 1990 & 1 \\
\hline 76 & Well 1187 & 380630 & 0941616 & $\begin{array}{c}\text { USGS, } \\
\text { (Coop-MODOH) }\end{array}$ & WIPC & 34.8 & 1990 & 1 \\
\hline 77 & Well 2110 & 380736 & 0935735 & $\begin{array}{c}\text { USGS, } \\
\text { (Coop-MODOH) }\end{array}$ & WIPC & 170 & 1990 & 1 \\
\hline 78 & Well 1003 & 380748 & 0942512 & $\begin{array}{c}\text { USGS, } \\
\text { (Coop-MODOH) }\end{array}$ & WIPC & 120 & 1990 & 1 \\
\hline 79 & Well 1905a (field) & 380752 & 0941222 & $\begin{array}{c}\text { USGS, } \\
\text { (Coop-MODOH) }\end{array}$ & WIPC & 29.1 & 1990 & 1 \\
\hline 80 & Well 1905 & 380809 & 0941231 & $\begin{array}{c}\text { USGS, } \\
\text { (Coop-MODOH) }\end{array}$ & WIPC & 15.8 & 1990 & 1 \\
\hline 81 & Well 2801 & 380838 & 0940144 & $\begin{array}{c}\text { USGS, } \\
\text { (Coop-MODOH) }\end{array}$ & WIPC & 260 & 1990 & 1 \\
\hline 82 & Well 1910 & 380905 & 0940910 & $\begin{array}{c}\text { USGS, } \\
\text { (Coop-MODOH) }\end{array}$ & WIPC & 17.2 & 1990 & 1 \\
\hline 83 & Well 1191 & 380924 & 0940835 & $\begin{array}{c}\text { USGS, } \\
\text { (Coop-MODOH) }\end{array}$ & ALVM & 18.4 & 1990 & 1 \\
\hline 84 & Well 2803 & 381004 & 0935521 & $\begin{array}{c}\text { USGS, } \\
\text { (Coop-MODOH) }\end{array}$ & SPAQ & 310 & 1990 & 1 \\
\hline 85 & Well 1172 & 381115 & 0942003 & $\begin{array}{c}\text { USGS, } \\
\text { (Coop-MODOH) }\end{array}$ & WIPC & 22 & 1990 & 1 \\
\hline 86 & Well 1028 & 381119 & 0943110 & $\begin{array}{c}\text { USGS, } \\
\text { (Coop-MODOH) }\end{array}$ & WIPC & 200 & 1990 & 1 \\
\hline 87 & Well 1188 & 381150 & 0941009 & $\begin{array}{c}\text { USGS, } \\
\text { (Coop-MODOH) }\end{array}$ & WIPC & 16.75 & 1990 & 1 \\
\hline 88 & Well 1175 & 381157 & 0942008 & $\begin{array}{c}\text { USGS, } \\
\text { (Coop-MODOH) }\end{array}$ & WIPC & 8 & 1990 & 1 \\
\hline 89 & Well 2909 & 381204 & 0935832 & $\begin{array}{c}\text { USGS, } \\
\text { (Coop-MODOH) }\end{array}$ & WIPC & 180 & 1990 & 1 \\
\hline 90 & Well 1174 & 381213 & 0942600 & $\begin{array}{c}\text { USGS, } \\
\text { (Coop-MODOH) }\end{array}$ & WIPC & -- & 1990 & 1 \\
\hline 91 & Well 1170 & 381418 & 0941207 & $\begin{array}{c}\text { USGS, } \\
\text { (Coop-MODOH) }\end{array}$ & WIPC & 51.5 & 1990 & 1 \\
\hline 92 & Well 1017 & 381620 & 0941943 & $\begin{array}{c}\text { USGS, } \\
\text { (Coop-MODOH) }\end{array}$ & WIPC & 46.4 & 1990 & 1 \\
\hline
\end{tabular}


Table 7. Site and basin characteristics of bed-sediment sampling sites

$\left[\mathrm{mi}^{2}\right.$, square mile; WY70-90, water years 1970-1990; --, data unavailable; USGS, U.S. Geological Survey; ODEQ, Oklahoma Department of Environmental Quality; ADPCE, Arkansas Department of Pollution Control and Ecology; USEPA, U.S. Environmental Protection Agency]

\begin{tabular}{|c|c|c|c|c|c|c|c|c|}
\hline $\begin{array}{c}\text { Site } \\
\text { number }\end{array}$ & Site name & Latitude & Longitude & $\begin{array}{c}\text { Drainage } \\
\text { area } \\
\left(\mathbf{m i}^{2}\right)\end{array}$ & $\begin{array}{l}\text { Collecting } \\
\text { agency }\end{array}$ & $\begin{array}{l}\text { Physio- } \\
\text { graphic } \\
\text { area }^{1}\end{array}$ & $\begin{array}{c}\text { Period of } \\
\text { record } \\
(\text { WY70-90) }\end{array}$ & $\begin{array}{c}\text { Number } \\
\text { of } \\
\text { samples }\end{array}$ \\
\hline 1 & Buffalo River near Harriet, Ark. & 360403 & 923438 & -- & USGS & Boston & $1979-82$ & 4 \\
\hline 2 & White River at Calico Rock, Ark. & 360658 & 920835 & 9,978 & USGS & $\begin{array}{l}\text { Salem, Boston, } \\
\text { Springfield }\end{array}$ & 1975 & 2 \\
\hline 3 & $\begin{array}{l}\text { North Sylamore Creek near } \\
\text { Fifty Six, Ark. }\end{array}$ & 355943 & 921245 & 58 & USGS & Springfield & $1970-81$ & 9 \\
\hline 4 & Spring River at Imboden, Ark. & 361219 & 911019 & 1,183 & USGS & Salem & 1970, 1971 & 2 \\
\hline 5 & Black River at Black Rock, Ark. & 360615 & 910550 & 7,369 & USGS & $\begin{array}{l}\text { Mississippi } \\
\text { Alluvial Plain, } \\
\text { Salem, } \\
\text { St. Francois }\end{array}$ & $1970-73$ & 3 \\
\hline 6 & $\begin{array}{l}\text { Illinois River near Tahlequah, } \\
\text { Okla. }\end{array}$ & 355522 & 945524 & 959 & $\begin{array}{l}\text { USGS, } \\
\text { ODEQ }\end{array}$ & Springfield & $1980-89$ & 6 \\
\hline 7 & $\begin{array}{l}\text { Illinois River at Highway } 64 \\
\text { Bridge, Okla. }\end{array}$ & 353100 & 950528 & -- & ODEQ & Springfield & $1981-90$ & 7 \\
\hline 8 & White River at Oil Trough, Ark. & 353836 & 912742 & -- & ADPCE & $\begin{array}{l}\text { Mississippi } \\
\text { Alluvial Plain, } \\
\text { Boston, Salem, } \\
\text { Springfield }\end{array}$ & 1983 & 1 \\
\hline 9 & $\begin{array}{l}\text { Fort Gibson near Dam (Neosho } \\
\text { River), Okla. }\end{array}$ & 355115 & 951345 & -- & USEPA & $\begin{array}{l}\text { Springfield, } \\
\text { Osage Plains }\end{array}$ & 1980 & 1 \\
\hline 10 & $\begin{array}{l}\text { Grand River below Fort Gibson } \\
\text { Reservoir, Okla. }\end{array}$ & 355115 & 951345 & -- & USEPA & $\begin{array}{l}\text { Springfield, } \\
\text { Osage Plains }\end{array}$ & 1981 & 1 \\
\hline 11 & Baron Fork at Eldon, Okla. & 355516 & 945018 & -- & ODEQ & Springfield & 1989 & 1 \\
\hline 12 & Buffalo River near St. Joe, Ark. & 355902 & 924444 & 829 & ADPCE & $\begin{array}{l}\text { Boston, } \\
\text { Springfield }\end{array}$ & 1983 & 1 \\
\hline 13 & $\begin{array}{l}\text { White River below Fayetteville, } \\
\text { Ark. }\end{array}$ & 360000 & 940000 & -- & USEPA & $\begin{array}{l}\text { Boston, } \\
\text { Springfield }\end{array}$ & 1981 & 1 \\
\hline 14 & $\begin{array}{l}\text { Strawberry River near } \\
\text { Smithville, Ark. }\end{array}$ & 360140 & 911931 & -- & ADPCE & Salem & 1976 & 2 \\
\hline 15 & $\begin{array}{l}\text { Illinois River south of } \\
\text { Siloam Springs, Ark. }\end{array}$ & 360631 & 943200 & -- & ADPCE & Springfield & 1977 & 1 \\
\hline 16 & Illinois River near Watts, Okla. & 360748 & 943412 & 635 & ODEQ & Springfield & 1986, 1989 & 2 \\
\hline 17 & $\begin{array}{l}\text { Grand Neosho River above } \\
\text { Industrial Park, Okla. }\end{array}$ & 361051 & 951625 & -- & ODEQ & $\begin{array}{l}\text { Springfield, } \\
\text { Osage Plains }\end{array}$ & 1990 & 1 \\
\hline 18 & Flint Creek near Kansas, Okla. & 361154 & 944230 & -- & ODEQ & Springfield & 1986, 1989 & 2 \\
\hline 19 & $\begin{array}{l}\text { Neosho River at State } \\
\text { Highway } 33 \text { Bridge, Okla. }\end{array}$ & 361345 & 951059 & -- & ODEQ & $\begin{array}{l}\text { Springfield, } \\
\text { Osage Plains }\end{array}$ & 1990 & 1 \\
\hline 20 & $\begin{array}{l}\text { Eleven Point River near } \\
\text { Pocahontas, Ark. }\end{array}$ & 361413 & 910505 & -- & ADPCE & Salem & 1976 & 1 \\
\hline 21 & $\begin{array}{l}\text { Pryor Creek at Highway } \\
69 \text { a Bridge, Okla. }\end{array}$ & 361455 & 951530 & -- & ODEQ & Osage Plains & 1990 & 1 \\
\hline 22 & Spring River near Hardy, Ark. & 362000 & 913030 & -- & ADPCE & Salem & 1976 & 2 \\
\hline
\end{tabular}


Table 7. Site and basin characteristics of bed-sediment sampling sites--Continued

[mi² , square mile; WY70-90, water years 1970-1990; --, data unavailable; USGS, U.S. Geological Survey; ODEQ, Oklahoma Department of Environmental Quality; ADPCE, Arkansas Department of Pollution Control and Ecology; USEPA, U.S. Environmental Protection Agency]

\begin{tabular}{|c|c|c|c|c|c|c|c|c|}
\hline $\begin{array}{c}\text { Site } \\
\text { number }\end{array}$ & Site name & Latitude & Longitude & $\begin{array}{c}\text { Drainage } \\
\text { area } \\
\left(\mathbf{m i}^{2}\right)\end{array}$ & $\begin{array}{l}\text { Collecting } \\
\text { agency }\end{array}$ & $\begin{array}{l}\text { Physio- } \\
\text { graphic } \\
\text { area }^{1}\end{array}$ & $\begin{array}{c}\text { Period of } \\
\text { record } \\
(\text { WY70-90) }\end{array}$ & $\begin{array}{c}\text { Number } \\
\text { of } \\
\text { samples }\end{array}$ \\
\hline 23 & $\begin{array}{l}\text { Spavinaw Creek north of } \\
\text { Cherokee City, Ark. }\end{array}$ & 362031 & 943515 & -- & ADPCE & Springfield & 1983 & 1 \\
\hline 24 & Kings River near Berryville, Ark. & 362536 & 933715 & 527 & ADPCE & $\begin{array}{l}\text { Salem, Boston, } \\
\text { Springfield }\end{array}$ & 1983,1984 & 2 \\
\hline 25 & Neosho River near Langley, Okla. & 362615 & 950244 & -- & ODEQ & $\begin{array}{l}\text { Springfield, } \\
\text { Osage Plains }\end{array}$ & 1990 & 1 \\
\hline 26 & Neosho River near Commerce, Okla. & 365543 & 945726 & -- & ODEQ & Osage Plains & 1990 & 1 \\
\hline 27 & $\begin{array}{l}\text { Spring River at Devil's } \\
\text { Prominade Bridge, Okla. }\end{array}$ & 365604 & 944445 & -- & ODEQ & $\begin{array}{l}\text { Osage Plains, } \\
\text { Springfield }\end{array}$ & 1981,1990 & 2 \\
\hline 28 & $\begin{array}{l}\text { Celia's Spring River trout } \\
\text { farm pond, Mo. }\end{array}$ & 365630 & 934720 & -- & USEPA & Springfield & 1981 & 1 \\
\hline 29 & $\begin{array}{l}\text { Spring River at Business } \\
\text { Route } 60 \text { Bridge, Mo. }\end{array}$ & 365655 & 934737 & -- & USEPA & Springfield & 1981 & 1 \\
\hline 30 & $\begin{array}{l}\text { Spring River } 315 \mathrm{ft} \text { upstream } \\
\text { of Douger Bridge, Mo. }\end{array}$ & 365826 & 934754 & -- & USEPA & Springfield & 1981 & 1 \\
\hline 31 & $\begin{array}{l}\text { Spring River } 2.4 \text { mi down- } \\
\text { stream of Douger Bridge, Mo. }\end{array}$ & 365951 & 934859 & -- & USEPA & Springfield & 1981 & 1 \\
\hline 32 & $\begin{array}{l}\text { Spring River } 5.9 \text { mi down- } \\
\text { stream of Douger Bridge, Mo. }\end{array}$ & 370330 & 935008 & -- & USEPA & Springfield & 1981 & 1 \\
\hline 33 & $\begin{array}{l}\text { Eagle-Picher Industries Inc., } \\
\text { Joplin, Mo. }\end{array}$ & 370635 & 943138 & -- & USEPA & Springfield & 1988 & 1 \\
\hline 34 & $\begin{array}{l}\text { Pomme Creek near Highway } 61 \\
\text { bridge, Mo. }\end{array}$ & 382522 & 902235 & -- & USEPA & Salem & 1990 & 1 \\
\hline 35 & $\begin{array}{l}\text { Meramec River below Saline } \\
\text { Creek, Mo. }\end{array}$ & 382705 & 902345 & -- & USEPA & $\begin{array}{l}\text { Salem, } \\
\text { St. Francois }\end{array}$ & 1988 & 1 \\
\hline 36 & $\begin{array}{l}\text { Big River } 2 \text { miles above } \\
\text { mouth, Mo. }\end{array}$ & 382743 & 903636 & -- & USEPA & $\begin{array}{l}\text { Salem, } \\
\text { St. Francois }\end{array}$ & 1988 & 1 \\
\hline 37 & $\begin{array}{l}\text { Romaine Creek near } \\
\text { Paulina Hills, Mo. }{ }^{3}\end{array}$ & 382750 & 902600 & -- & USEPA & Salem & 1990 & 1 \\
\hline 38 & Meramec River at Pacific, Mo. & 382800 & 904410 & -- & USEPA & Salem & 1988 & 1 \\
\hline 39 & $\begin{array}{l}\text { Meramec River below Fenton } \\
\text { Creek, Mo. }\end{array}$ & 382840 & 902520 & -- & USEPA & $\begin{array}{l}\text { Salem, } \\
\text { St. Francois }\end{array}$ & 1988 & 1 \\
\hline 40 & $\begin{array}{l}\text { Meramec River upstream I44 } \\
\text { bridge at Times Beach, Mo. }\end{array}$ & 383013 & 903525 & -- & USEPA & $\begin{array}{l}\text { Salem, } \\
\text { St. Francois }\end{array}$ & 1983 & 1 \\
\hline 41 & $\begin{array}{l}\text { Antire Creek near confluence } \\
\text { with the Meramec River, Mo. }\end{array}$ & 383022 & 903355 & -- & USEPA & Salem & 1990 & 1 \\
\hline 42 & $\begin{array}{l}\text { Unnamed tributary of the } \\
\text { Meramec River, Mo. }\end{array}$ & 383137 & 902647 & -- & USEPA & Salem & 1990 & 1 \\
\hline 43 & $\begin{array}{l}\text { Meramec River below } \\
\text { Flat Creek, Mo. }\end{array}$ & 383155 & 903735 & -- & USEPA & $\begin{array}{l}\text { Salem, } \\
\text { St. Francois }\end{array}$ & 1988 & 1 \\
\hline 44 & $\begin{array}{l}\text { Meramec River downstream } \\
\text { of Glencoe, Mo. }\end{array}$ & 383232 & 903507 & -- & USEPA & $\begin{array}{l}\text { Salem, } \\
\text { St. Francois }\end{array}$ & 1983 & 1 \\
\hline 45 & Carr Creek near Glencoe, Mo. ${ }^{5}$ & 383240 & 903748 & -- & USEPA & Salem & 1990 & 1 \\
\hline
\end{tabular}


Table 7. Site and basin characteristics of bed-sediment sampling sites--Continued

$\left[\mathrm{mi}^{2}\right.$, square mile; WY70-90, water years 1970-1990; --, data unavailable; USGS, U.S. Geological Survey; ODEQ, Oklahoma Department of Environmental Quality; ADPCE, Arkansas Department of Pollution Control and Ecology; USEPA, U.S. Environmental Protection Agency]

\begin{tabular}{|c|c|c|c|c|c|c|c|c|}
\hline $\begin{array}{c}\text { Site } \\
\text { number }\end{array}$ & Site name & Latitude & Longitude & $\begin{array}{c}\text { Drainage } \\
\text { area } \\
\left(\mathbf{m i}^{2}\right)\end{array}$ & $\begin{array}{l}\text { Collecting } \\
\text { agency }\end{array}$ & $\begin{array}{c}\text { Physio- } \\
\text { graphic } \\
\text { area }^{1}\end{array}$ & $\begin{array}{c}\text { Period of } \\
\text { record } \\
\text { (WY70-90) }\end{array}$ & $\begin{array}{c}\text { Number } \\
\text { of } \\
\text { samples }\end{array}$ \\
\hline 46 & $\begin{array}{l}\text { Meramec River below } \\
\text { Fishpot Creek, Mo. }\end{array}$ & 383252 & 902905 & -- & USEPA & $\begin{array}{l}\text { Salem, } \\
\text { St. Francois }\end{array}$ & 1988 & 1 \\
\hline 47 & $\begin{array}{l}\text { Meramec River below } \\
\text { Kiefer Creek, Mo. }\end{array}$ & 383255 & 903138 & -- & USEPA & $\begin{array}{l}\text { Salem, } \\
\text { St. Francois }\end{array}$ & 1988 & 1 \\
\hline 48 & $\begin{array}{l}\text { Kiefer Creek near confluence } \\
\text { with the Meramec River, Mo. }{ }^{6}\end{array}$ & 383324 & 903240 & -- & USEPA & Salem & 1990 & 1 \\
\hline 49 & $\begin{array}{l}\text { Meramec River below Grand } \\
\text { Glaize Creek, Mo. }\end{array}$ & 383325 & 902618 & -- & USEPA & $\begin{array}{l}\text { Salem, } \\
\text { St. Francois }\end{array}$ & 1988 & 1 \\
\hline 50 & $\begin{array}{l}\text { Meramec River near Kirkwood } \\
\text { wastewater treatment intake, Mo. }\end{array}$ & 383334 & 902645 & -- & USEPA & $\begin{array}{l}\text { Salem, } \\
\text { St. Francois }\end{array}$ & 1983 & 1 \\
\hline 51 & $\begin{array}{l}\text { Grand Glaize Creek at Big } \\
\text { Bend Road, Mo. }\end{array}$ & 383355 & 902820 & -- & USEPA & Salem & 1988 & 1 \\
\hline 52 & $\begin{array}{l}\text { Sugar Creek above confluence } \\
\text { with Romaine Creek, Mo. }{ }^{7}\end{array}$ & 383435 & 902750 & -- & USEPA & Salem & 1990 & 1 \\
\hline 53 & $\begin{array}{l}\text { Grand Glaize Creek at Doughtery } \\
\text { Ferry Road, Mo. }\end{array}$ & 383435 & 902815 & -- & USEPA & Salem & 1990 & 1 \\
\hline 54 & $\begin{array}{l}\text { Grand Glaize Creek at Barrett } \\
\text { Station Road, Mo. }\end{array}$ & 383457 & 902800 & -- & USEPA & Salem & 1988 & 1 \\
\hline 55 & $\begin{array}{l}\text { Grand Glaize Creek at Deitrich } \\
\text { Road, Mo. }\end{array}$ & 383548 & 902915 & -- & USEPA & Salem & 1990 & 1 \\
\hline
\end{tabular}

${ }^{1}$ Boston, Boston Mountains; Salem, Salem Plateau; Springfield, Springfield Plateau; St. Francois, St. Francois Mountains.

${ }^{2}$ Original site name is "Pomme Creek"; reference to location added for clarification.

${ }^{3}$ Original site name is "Romaine Creek"; reference to location added for clarification.

${ }^{4}$ Original site name is "Antire Creek"; reference to location added for clarification.

${ }^{5}$ Original site name is "Carr Creek"; reference to location added for clarification.

${ }^{6}$ Original site name is "Kiefer Creek"; reference to location added for clarification.

${ }^{7}$ Original site name is "Sugar Creek"; reference to location added for clarification. 
Table 8. Site and basin characteristics of biological-tissue sampling sites

$\left[\mathrm{mi}^{2}\right.$, square miles; WY70-90, water years 1970-1990; --, data unavailable; ODEQ, Oklahoma Department of Environmental Quality; ADPCE, Arkansas Department of Pollution Control and Ecology; USEPA, U.S. Environmental Protection Agency; KDHE, Kansas Department of Health and Environment; USCOE, U.S. Army Corps of Engineers]

\begin{tabular}{|c|c|c|c|c|c|c|c|c|}
\hline $\begin{array}{c}\text { Site } \\
\text { number }\end{array}$ & Site name & Latitude & Longitude & $\begin{array}{l}\text { Drainage area } \\
\qquad\left(\mathrm{mi}^{2}\right)\end{array}$ & $\begin{array}{l}\text { Collecting } \\
\text { agency }\end{array}$ & $\begin{array}{l}\text { Physio- } \\
\text { graphic } \\
\text { area }^{1}\end{array}$ & $\begin{array}{l}\text { Period of } \\
\text { record } \\
(\text { WY70-90) }\end{array}$ & $\begin{array}{c}\text { Number } \\
\text { of } \\
\text { samples }\end{array}$ \\
\hline 1 & $\begin{array}{l}\text { Illinois River at Highway } \\
64 \text { Bridge, Okla. }\end{array}$ & 353100 & 950528 & -- & ODEQ & Springfield & $1979-90$ & 13 \\
\hline 2 & $\begin{array}{l}\text { White River at Oil Trough, } \\
\text { Ark. }\end{array}$ & 353836 & 912742 & -- & ADPCE & $\begin{array}{l}\text { Mississippi Alluvial } \\
\text { Plain, Boston, Salem, } \\
\text { Springfield }\end{array}$ & $1985-87$ & 8 \\
\hline 3 & $\begin{array}{l}\text { Grand Neosho River near } \\
\text { Fort Gibson Dam, Okla. }\end{array}$ & 355115 & 951345 & -- & USEPA & $\begin{array}{l}\text { Springfield, } \\
\text { Osage Plains }\end{array}$ & 1981 & 1 \\
\hline 4 & $\begin{array}{l}\text { Illinois River near } \\
\text { Tahlequah, Okla. }\end{array}$ & 355522 & 945524 & 959 & ODEQ & Springfield & $1978-90$ & 19 \\
\hline 5 & $\begin{array}{l}\text { Buffalo River near St. Joe, } \\
\text { Ark. }\end{array}$ & 355902 & 924444 & 829 & ADPCE & $\begin{array}{l}\text { Boston, } \\
\text { Springfield }\end{array}$ & $1978-81$ & 4 \\
\hline 6 & $\begin{array}{l}\text { Buffalo River near Hasty, } \\
\text { Ark. }\end{array}$ & 355903 & 930230 & -- & ADPCE & $\begin{array}{l}\text { Boston, } \\
\text { Springfield }\end{array}$ & 1984 & 1 \\
\hline 7 & $\begin{array}{l}\text { North Sylamore Creek near } \\
\text { Fifty Six, Ark. }\end{array}$ & 355943 & 921245 & 58 & USEPA & Springfield & 1985 & 1 \\
\hline 8 & $\begin{array}{l}\text { White River below } \\
\text { Fayetteville, Ark. }\end{array}$ & 360000 & 940000 & -- & USEPA & $\begin{array}{l}\text { Boston, } \\
\text { Springfield }\end{array}$ & 1981 & 1 \\
\hline 9 & $\begin{array}{l}\text { West Fork White River east } \\
\text { of Fayetteville, Ark. }\end{array}$ & 360300 & 940442 & -- & ADPCE & $\begin{array}{l}\text { Boston, } \\
\text { Springfield }\end{array}$ & 1974 & 1 \\
\hline 10 & $\begin{array}{l}\text { Fort Gibson Lake at Pryer } \\
\text { Creek, Okla. }\end{array}$ & 360400 & 951600 & -- & USEPA & $\begin{array}{l}\text { Osage Plains, } \\
\text { Springfield }\end{array}$ & 1986, 87 & 2 \\
\hline 11 & $\begin{array}{l}\text { White River near Goshen, } \\
\text { Ark. }\end{array}$ & 360621 & 940041 & -- & ADPCE & $\begin{array}{l}\text { Boston, } \\
\text { Springfield }\end{array}$ & $1974-86$ & 3 \\
\hline 12 & $\begin{array}{l}\text { Illinois River south of } \\
\text { Siloam Springs, Ark. }\end{array}$ & 360631 & 943200 & -- & ADPCE & Springfield & 1977 & 1 \\
\hline 13 & $\begin{array}{l}\text { Sager Creek near Siloam } \\
\text { Springs, Ark. }\end{array}$ & 361150 & 943500 & -- & ADPCE & Springfield & 1973 & 2 \\
\hline 14 & $\begin{array}{l}\text { White River near Norfork, } \\
\text { Ark. }\end{array}$ & 361324 & 921806 & -- & ADPCE & $\begin{array}{l}\text { Salem, Boston, } \\
\text { Springfield }\end{array}$ & $1985-87$ & 8 \\
\hline 15 & $\begin{array}{l}\text { Spavinaw Creek north of } \\
\text { Sycamore, Okla. }\end{array}$ & 361351 & 943320 & -- & ADPCE & Springfield & $1973-79$ & 4 \\
\hline 16 & $\begin{array}{l}\text { Flint Creek north of } \\
\text { Siloam Springs, Ark. }\end{array}$ & 361353 & 943320 & -- & ADPCE & Springfield & 1972 & 1 \\
\hline 17 & $\begin{array}{l}\text { Crooked Creek below } \\
\text { Harrison, Ark. }\end{array}$ & 361439 & 930339 & -- & ADPCE & Springfield & 1986 & 1 \\
\hline 18 & $\begin{array}{l}\text { Pryor Creek at Highway } \\
69 \text { a Bridge, Okla. }\end{array}$ & 361455 & 951530 & -- & ODEQ & Osage Plains & 1980 & 1 \\
\hline 19 & $\begin{array}{l}\text { Current River near } \\
\text { Pocahontas, Ark. }\end{array}$ & 361755 & 905130 & 2,606 & ADPCE & $\begin{array}{l}\text { Mississippi Alluvial } \\
\text { Plain, Salem }\end{array}$ & 1973 & 2 \\
\hline 20 & $\begin{array}{l}\text { Spavinaw Creek near } \\
\text { Cherokee City, Ark. }\end{array}$ & 362031 & 943515 & -- & ADPCE & Springfield & $1978-83$ & 4 \\
\hline 21 & $\begin{array}{l}\text { Eleven Point River near } \\
\text { Ravenden Springs, Ark. }\end{array}$ & 362048 & 910648 & 1,134 & ADPCE & Salem & $1972-73$ & 3 \\
\hline
\end{tabular}


Table 8. Site and basin characteristics of biological-tissue sampling sites--Continued

[mi $^{2}$, square miles; WY70-90, water years 1970-1990; --, data unavailable; ODEQ, Oklahoma Department of Environmental Quality; ADPCE, Arkansas Department of Pollution Control and Ecology; USEPA, U.S. Environmental Protection Agency; KDHE, Kansas Department of Health and Environment; USCOE, U.S. Army Corps of Engineers]

\begin{tabular}{|c|c|c|c|c|c|c|c|c|}
\hline $\begin{array}{c}\text { Site } \\
\text { number }\end{array}$ & Site name & Latitude & Longitude & $\begin{array}{l}\text { Drainage area } \\
\qquad\left(\mathrm{mi}^{2}\right)\end{array}$ & $\begin{array}{l}\text { Collecting } \\
\text { agency }\end{array}$ & $\begin{array}{l}\text { Physio- } \\
\text { graphic } \\
\text { area }^{1}\end{array}$ & $\begin{array}{c}\text { Period of } \\
\text { record } \\
(\text { WY70-90) }\end{array}$ & $\begin{array}{c}\text { Number } \\
\text { of } \\
\text { samples }\end{array}$ \\
\hline 22 & $\begin{array}{l}\text { Black River near } \\
\text { Corning, Ark. }\end{array}$ & 362407 & 903229 & 1,749 & ADPCE & $\begin{array}{l}\text { Mississippi Alluvial } \\
\text { Plain, Salem, } \\
\text { St. Francois }\end{array}$ & 1973-74 & 3 \\
\hline 23 & $\begin{array}{l}\text { White River near Eureka } \\
\text { Springs, Ark. }\end{array}$ & 362515 & 935050 & 1,192 & ADPCE & $\begin{array}{l}\text { Salem, Boston, } \\
\text { Springfield }\end{array}$ & 1973 & 3 \\
\hline 24 & $\begin{array}{l}\text { Kings River near } \\
\text { Berryville, Ark. }\end{array}$ & 362536 & 933715 & 527 & ADPCE & $\begin{array}{l}\text { Salem, Boston, } \\
\text { Springfield }\end{array}$ & $1973-84$ & 8 \\
\hline 25 & $\begin{array}{l}\text { South Fork of Spring } \\
\text { River near Salem, Ark. }\end{array}$ & 362623 & 914944 & -- & ADPCE & Salem & 1973 & 2 \\
\hline 26 & $\begin{array}{l}\text { Spring River near Thayer, } \\
\text { Mo. }\end{array}$ & 363010 & 913131 & -- & ADPCE & Salem & $1972-73$ & 3 \\
\hline 27 & $\begin{array}{l}\text { Little Sugar Creek at } \\
\text { Caverna, Mo. }\end{array}$ & 363010 & 941630 & -- & ADPCE & Springfield & 1973 & 3 \\
\hline 28 & $\begin{array}{l}\text { Butler Creek near } \\
\text { Sulphur Springs, Ark. }\end{array}$ & 363044 & 942854 & -- & ADPCE & Springfield & 1973 & 3 \\
\hline 29 & $\begin{array}{l}\text { Myatt Creek near } \\
\text { Thayer, Mo. }\end{array}$ & 363104 & 914418 & -- & ADPCE & Salem & $1972-73$ & 3 \\
\hline 30 & $\begin{array}{l}\text { Eleven Point River west } \\
\text { of Calm, Mo. }\end{array}$ & 363300 & 911136 & -- & USEPA & Salem & $1986-88$ & 3 \\
\hline 31 & $\begin{array}{l}\text { North Fork River west of } \\
\text { Tecumseh, Mo. }\end{array}$ & 363515 & 921720 & -- & USEPA & Salem & 1980 & 1 \\
\hline 32 & $\begin{array}{l}\text { Elk River at Cowskin } \\
\text { access south of Tiff City, } \\
\text { Kans. }\end{array}$ & 363800 & 943524 & -- & USEPA & Springfield & 1982 & 1 \\
\hline 33 & $\begin{array}{l}\text { Lake Taneycomo and } \\
\text { Roark Creek Confluence, } \\
\text { Mo. }\end{array}$ & 363903 & 931254 & -- & USEPA & $\begin{array}{l}\text { Salem, Springfield, } \\
\text { Boston Mountains }\end{array}$ & 1981 & 2 \\
\hline 34 & $\begin{array}{l}\text { Current River west of } \\
\text { Doniphan, Mo. }\end{array}$ & 363952 & 905024 & -- & USEPA & Salem & $1980-84$ & 4 \\
\hline 35 & $\begin{array}{l}\text { Lake Taneycomo } 3.1 \text { miles } \\
\text { below Branson, Mo. }\end{array}$ & 364021 & 931200 & -- & USEPA & $\begin{array}{l}\text { Salem, Springfield, } \\
\text { Boston Mountains }\end{array}$ & $1980-86$ & 5 \\
\hline 36 & $\begin{array}{l}\text { Current River NNW. of } \\
\text { Doniphan, Mo. }\end{array}$ & 364157 & 905236 & -- & USEPA & Salem & $1985-88$ & 4 \\
\hline 37 & $\begin{array}{l}\text { Spring River near } \\
\text { Verona, Mo. }\end{array}$ & 365600 & 934600 & -- & USEPA & Springfield & 1978 & 1 \\
\hline 38 & $\begin{array}{l}\text { Spring River at Devil's } \\
\text { Prominade Bridge, Okla. }\end{array}$ & 365604 & 944445 & -- & ODEQ & $\begin{array}{l}\text { Osage Plains, } \\
\text { Springfield }\end{array}$ & 1981 & 4 \\
\hline 39 & $\begin{array}{l}\text { Spring River } 0.6 \mathrm{mi} \\
\text { upstream from U.S. } 60 \\
\text { Bridge, Mo. }\end{array}$ & 365628 & 934656 & -- & USEPA & Springfield & 1981 & 1 \\
\hline 40 & $\begin{array}{l}\text { James River at Shelvin } \\
\text { Rock access, southeast of } \\
\text { Nixa, Mo. }\end{array}$ & 365747 & 932211 & -- & USEPA & Springfield & $1985-86$ & 2 \\
\hline 41 & $\begin{array}{l}\text { Unnamed Creek between } \\
\text { Syntex and Spring, Mo. }\end{array}$ & 365808 & 934757 & -- & USEPA & Springfield & 1981 & 1 \\
\hline
\end{tabular}


Table 8. Site and basin characteristics of biological-tissue sampling sites--Continued

$\left[\mathrm{mi}^{2}\right.$, square miles; WY70-90, water years 1970-1990; --, data unavailable; ODEQ, Oklahoma Department of Environmental Quality; ADPCE, Arkansas Department of Pollution Control and Ecology; USEPA, U.S. Environmental Protection Agency; KDHE, Kansas Department of Health and Environment; USCOE, U.S. Army Corps of Engineers]

\begin{tabular}{|c|c|c|c|c|c|c|c|c|}
\hline $\begin{array}{c}\text { Site } \\
\text { number }\end{array}$ & Site name & Latitude & Longitude & $\begin{array}{l}\text { Drainage area } \\
\qquad\left(\mathrm{mi}^{2}\right)\end{array}$ & $\begin{array}{c}\text { Collecting } \\
\text { agency }\end{array}$ & $\begin{array}{l}\text { Physio- } \\
\text { graphic } \\
\text { area }^{1}\end{array}$ & $\begin{array}{l}\text { Period of } \\
\text { record } \\
(\text { WY70-90) }\end{array}$ & $\begin{array}{l}\text { Number } \\
\text { of } \\
\text { samples }\end{array}$ \\
\hline 42 & $\begin{array}{l}\text { Spring River west of } \\
\text { Verona, Mo. }\end{array}$ & 365808 & 934803 & -- & USEPA & Springfield & 1981 & 1 \\
\hline 43 & $\begin{array}{l}\text { Douger Bridge at State } \\
\text { Route P in Lawrence County, Mo. }\end{array}$ & 365830 & 934741 & -- & USEPA & Springfield & 1981 & 1 \\
\hline 44 & $\begin{array}{l}\text { Spring River } 2.4 \mathrm{mi} \\
\text { downstream of Douger } \\
\text { Bridge, Mo. }\end{array}$ & 365951 & 934859 & -- & USEPA & Springfield & 1981 & 1 \\
\hline 45 & $\begin{array}{l}\text { James River near Boaz } \\
\text { below Wilson Creek, Mo. }\end{array}$ & 370025 & 932150 & 462 & USEPA & Springfield & $1980-84$ & 5 \\
\hline 46 & $\begin{array}{l}\text { Spring River at Baxter } \\
\text { Springs, Kans. }\end{array}$ & 370105 & 944314 & -- & USEPA & Springfield & $1980-86$ & 6 \\
\hline 47 & $\begin{array}{l}\text { Neosho River near Chetopa, } \\
\text { Kans. }\end{array}$ & 370210 & 950450 & -- & KDHE & Osage Plains & 1974-89 & 32 \\
\hline 48 & $\begin{array}{l}\text { Labette Creek near } \\
\text { Chetopa, Kans. }\end{array}$ & 370428 & 950611 & -- & KDHE & Osage Plains & 1990 & 2 \\
\hline 49 & $\begin{array}{l}\text { James River } 2 \text { mi above } \\
\text { Wilson Creek, Mo. }\end{array}$ & 370435 & 932215 & -- & USEPA & Springfield & 1978,80 & 2 \\
\hline 50 & $\begin{array}{l}\text { Short Creek near Galena, } \\
\text { Kans. }\end{array}$ & 370523 & 943958 & -- & KDHE & Springfield & 1990 & 1 \\
\hline 51 & $\begin{array}{l}\text { Wilson Creek downstream } \\
\text { of South Creek, Mo. }{ }^{2}\end{array}$ & 370624 & 932430 & -- & USEPA & Springfield & 1985 & 1 \\
\hline 52 & $\begin{array}{l}\text { Turkey Creek near Joplin, } \\
\text { Mo. }\end{array}$ & 370715 & 943455 & 42 & KDHE & Springfield & $1975-90$ & 18 \\
\hline 53 & $\begin{array}{l}\text { Shawnee Creek near } \\
\text { Crestline, Kans. }\end{array}$ & 370855 & 944038 & -- & KDHE & $\begin{array}{l}\text { Springfield, } \\
\text { Osage Plains }\end{array}$ & 1990 & 1 \\
\hline 54 & $\begin{array}{l}\text { Center Creek near } \\
\text { Smithfield, Mo. }\end{array}$ & 370921 & 943610 & -- & KDHE & Springfield & $1975-90$ & 17 \\
\hline 55 & $\begin{array}{l}\text { Center Creek east of } \\
\text { Carterville, Mo. }\end{array}$ & 370930 & 942420 & -- & USEPA & Springfield & 1980 & 1 \\
\hline 56 & $\begin{array}{l}\text { Center Creek south of } \\
\text { Smithfield, Mo. }\end{array}$ & 370930 & 943615 & -- & USEPA & Springfield & 1977 & 1 \\
\hline 57 & $\begin{array}{l}\text { Spring River east of } \\
\text { Waco, Mo. }\end{array}$ & 370948 & 943406 & -- & USEPA & Springfield & 1986-89 & 4 \\
\hline 58 & $\begin{array}{l}\text { Center Creek } 1 \text { mi south of } \\
\text { Carl Junction, Mo. }\end{array}$ & 370951 & 943339 & -- & USEPA & Springfield & $1985-86$ & 2 \\
\hline 59 & $\begin{array}{l}\text { Center Creek at Highway JJ } \\
\text { Bridge near Smithfield, Mo. }\end{array}$ & 370953 & 943454 & -- & USEPA & Springfield & $1981-84$ & 4 \\
\hline 60 & $\begin{array}{l}\text { Neosho River near Oswego, } \\
\text { Kans. }\end{array}$ & 370954 & 950346 & -- & KDHE & Osage Plains & 1990 & 2 \\
\hline 61 & $\begin{array}{l}\text { Wilson Creek upstream of } \\
\text { South Creek, Mo. }{ }^{3}\end{array}$ & 371006 & 932212 & -- & USEPA & Springfield & 1985 & 1 \\
\hline 62 & $\begin{array}{l}\text { Spring River near Galena, } \\
\text { Kans. }\end{array}$ & 371125 & 943805 & -- & USEPA & Springfield & 1977 & 1 \\
\hline
\end{tabular}


Table 8. Site and basin characteristics of biological-tissue sampling sites--Continued

[mi $^{2}$, square miles; WY70-90, water years 1970-1990; --, data unavailable; ODEQ, Oklahoma Department of Environmental Quality; ADPCE, Arkansas Department of Pollution Control and Ecology; USEPA, U.S. Environmental Protection Agency; KDHE, Kansas Department of Health and Environment; USCOE, U.S. Army Corps of Engineers]

\begin{tabular}{|c|c|c|c|c|c|c|c|c|}
\hline $\begin{array}{c}\text { Site } \\
\text { number }\end{array}$ & Site name & Latitude & Longitude & $\begin{array}{l}\text { Drainage area } \\
\qquad\left(\mathrm{mi}^{2}\right)\end{array}$ & $\begin{array}{l}\text { Collecting } \\
\text { agency }\end{array}$ & $\begin{array}{l}\text { Physio- } \\
\text { graphic } \\
\text { area }^{1}\end{array}$ & $\begin{array}{l}\text { Period of } \\
\text { record } \\
(\text { WY70-90) }\end{array}$ & $\begin{array}{c}\text { Number } \\
\text { of } \\
\text { samples }\end{array}$ \\
\hline 63 & $\begin{array}{l}\text { Labette Creek southwest of } \\
\text { Labette, Kans. }\end{array}$ & 371310 & 951155 & -- & USEPA & Osage Plains & 1988-89 & 2 \\
\hline 64 & $\begin{array}{l}\text { Spring River south of } \\
\text { Waco, Mo. }\end{array}$ & 371315 & 943615 & -- & USEPA & Springfield & $1977-84$ & 4 \\
\hline 65 & $\begin{array}{l}\text { Cow Creek near Lawton, } \\
\text { Kans. }\end{array}$ & 371321 & 943914 & -- & KDHE & Osage Plains & 1990 & 1 \\
\hline 66 & $\begin{array}{l}\text { Labette Creek near Labette, } \\
\text { Kans. }\end{array}$ & 371348 & 951152 & -- & KDHE & Osage Plains & 1990 & 2 \\
\hline 67 & $\begin{array}{l}\text { Spring River at State } 171 \\
\text { Bridge, southeast of Waco, } \\
\text { Mo. }\end{array}$ & 371356 & 943433 & -- & USEPA & Springfield & 1985 & 1 \\
\hline 68 & $\begin{array}{l}\text { Lightning Creek near } \\
\text { Oswego, Kans. }\end{array}$ & 371418 & 950238 & -- & KDHE & Osage Plains & 1990 & 2 \\
\hline 69 & $\begin{array}{l}\text { Spring River near Waco, } \\
\text { Mo. }\end{array}$ & 371444 & 943358 & 1,164 & KDHE & $\begin{array}{l}\text { Springfield, } \\
\text { Osage Plains }\end{array}$ & 1973-89 & 26 \\
\hline 70 & $\begin{array}{l}\text { Cow Creek } 1 \text { mile east of } \\
\text { Langdon, Kans. }\end{array}$ & 372120 & 944110 & -- & USEPA & Osage Plains & 1988-89 & 2 \\
\hline 71 & $\begin{array}{l}\text { Neosho River water station } \\
\text { no. } 1, \text { Kans. }\end{array}$ & 372918 & 950830 & -- & KDHE & Osage Plains & 1990 & 1 \\
\hline 72 & $\begin{array}{l}\text { Marmaton River near } \\
\text { Fort Scott, Kans. }\end{array}$ & 375113 & 944649 & -- & KDHE & Osage Plains & 1990 & 2 \\
\hline 73 & $\begin{array}{l}\text { Devil's Elbow on Big } \\
\text { Piney, Mo. }\end{array}$ & 375115 & 920400 & -- & USEPA & Salem & 1977 & 1 \\
\hline 74 & $\begin{array}{l}\text { Marmaton River east of } \\
\text { Fort Scott, Kans. }\end{array}$ & 375120 & 943822 & -- & USEPA & Osage Plains & 1988-89 & 2 \\
\hline 75 & $\begin{array}{l}\text { Marmaton River near } \\
\text { Fort Scott, Kans. }\end{array}$ & 375147 & 944036 & -- & KDHE & Osage Plains & $1975-90$ & 18 \\
\hline 76 & $\begin{array}{l}\text { Gasconade at Highway } \\
\text { Y, Mo. }\end{array}$ & 375400 & 920800 & -- & USEPA & Salem & 1977 & 1 \\
\hline 77 & $\begin{array}{l}\text { Gasconade River near } \\
\text { Jerome, Mo. }\end{array}$ & 375512 & 915833 & -- & USEPA & Salem & $1977-89$ & 11 \\
\hline 78 & $\begin{array}{l}\text { Osage River at } \\
\text { Roscoe, Mo. }\end{array}$ & 375915 & 934845 & -- & USEPA & Osage Plains & 1987 & 1 \\
\hline 79 & $\begin{array}{l}\text { Little Osage River near } \\
\text { Fulton, Kans. }\end{array}$ & 380029 & 944142 & -- & KDHE & Osage Plains & $1975-90$ & 18 \\
\hline 80 & $\begin{array}{l}\text { Big River at Mammouth } \\
\text { access west of Desoto, Mo. }\end{array}$ & 380720 & 904036 & -- & USEPA & $\begin{array}{l}\text { Salem, } \\
\text { St. Francois }\end{array}$ & 1980 & 1 \\
\hline 81 & $\begin{array}{l}\text { Lake of the Ozarks at } \\
\text { Jennings Branch Cove, Mo. }\end{array}$ & 381202 & 923851 & -- & USEPA & Salem & $1985-86$ & 2 \\
\hline 82 & $\begin{array}{l}\text { Osage Gasconade, Bagnell } \\
\text { Dam, Mo. }\end{array}$ & 381220 & 923745 & -- & USEPA & Salem & 1971 & 2 \\
\hline 83 & $\begin{array}{l}\text { Meramec River at Meramec } \\
\text { Park, Mo. }\end{array}$ & 381400 & 910500 & -- & USEPA & Salem & 1977 & 1 \\
\hline
\end{tabular}


Table 8. Site and basin characteristics of biological-tissue sampling sites--Continued

$\left[\mathrm{mi}^{2}\right.$, square miles; WY70-90, water years 1970-1990; --, data unavailable; ODEQ, Oklahoma Department of Environmental Quality; ADPCE, Arkansas Department of Pollution Control and Ecology; USEPA, U.S. Environmental Protection Agency; KDHE, Kansas Department of Health and Environment; USCOE, U.S. Army Corps of Engineers]

\begin{tabular}{|c|c|c|c|c|c|c|c|c|}
\hline $\begin{array}{c}\text { Site } \\
\text { number }\end{array}$ & Site name & Latitude & Longitude & $\begin{array}{l}\text { Drainage area } \\
\qquad\left(\mathrm{mi}^{2}\right)\end{array}$ & $\begin{array}{c}\text { Collecting } \\
\text { agency }\end{array}$ & $\begin{array}{l}\text { Physio- } \\
\text { graphic } \\
\text { area }^{1}\end{array}$ & $\begin{array}{c}\text { Period of } \\
\text { record } \\
(\text { WY70-90) }\end{array}$ & $\begin{array}{c}\text { Number } \\
\text { of } \\
\text { samples }\end{array}$ \\
\hline 84 & $\begin{array}{l}\text { Truman Lake near } \\
\text { Brownington, Mo. }\end{array}$ & 381538 & 934342 & -- & USEPA & Osage Plains & 1987 & 1 \\
\hline 85 & $\begin{array}{l}\text { Truman Lake south-south } \\
\text { east of Clinton, Mo. }\end{array}$ & 381952 & 934610 & -- & USEPA & Osage Plains & $1987-88$ & 3 \\
\hline 86 & Calvey Creek no. 1, Mo. & 382200 & 904400 & -- & USEPA & Salem & 1977 & 1 \\
\hline 87 & $\begin{array}{l}\text { Tebo Creek, Henry Co. } \\
\text { Highway PP, Mo. }\end{array}$ & 382204 & 933240 & -- & USCOE & $\begin{array}{l}\text { Springfield, } \\
\text { Osage Plains }\end{array}$ & 1988 & 1 \\
\hline 88 & Calvey Creek no. 2, Mo. & 382300 & 904600 & -- & USEPA & Salem & 1977 & 1 \\
\hline 89 & Calvey Creek no. 3, Mo. & 382350 & 904610 & -- & USEPA & Salem & 1977 & 1 \\
\hline 90 & $\begin{array}{l}\text { Meramec River } 1 \mathrm{mi} \\
\text { upstream of Mississippi } \\
\text { River confluence, Mo. }\end{array}$ & 382418 & 902053 & -- & USEPA & Salem & 1984 & 1 \\
\hline 91 & $\begin{array}{l}\text { Osage River north of } \\
\text { St. Thomas, Mo. }\end{array}$ & 382518 & 921231 & -- & USEPA & $\begin{array}{l}\text { Salem, Springfield, } \\
\text { Osage Plains }\end{array}$ & 1981-89 & 9 \\
\hline 92 & $\begin{array}{l}\text { Meramec River northeast of } \\
\text { Arnold, Mo. }\end{array}$ & 382723 & 902139 & -- & USEPA & Salem & 1984 & 1 \\
\hline 93 & $\begin{array}{l}\text { Meramec River east of } \\
\text { Paulina Hills, Mo. }\end{array}$ & 382745 & 902459 & -- & USEPA & Salem & 1984 & 1 \\
\hline 94 & $\begin{array}{l}\text { Meramec River at Highway } \\
21 \text { Bridge, Mo. }\end{array}$ & 382745 & 902500 & -- & USEPA & Salem & 1983 & 2 \\
\hline 95 & $\begin{array}{l}\text { Romaine Creek near } \\
\text { mouth, Mo. }\end{array}$ & 382748 & 902527 & -- & USEPA & Salem & 1983 & 3 \\
\hline 96 & $\begin{array}{l}\text { Romaine Creek upstream } \\
\text { of Highway } 141 \text { Bridge, } \\
\text { Mo. }\end{array}$ & 382748 & 902543 & -- & USEPA & Salem & 1984 & 1 \\
\hline 97 & $\begin{array}{l}\text { Romaine Creek } 0.5 \text { miles } \\
\text { above the Meramec River, } \\
\text { Mo. }\end{array}$ & 382750 & 902524 & -- & USEPA & Salem & 1985 & 1 \\
\hline 98 & $\begin{array}{l}\text { Romaine Creek upstream } \\
\text { of the Saline Creek } \\
\text { confluence, Mo. }\end{array}$ & 382753 & 902514 & -- & USEPA & Salem & 1985 & 1 \\
\hline 99 & $\begin{array}{l}\text { Saline Creek upstream of } \\
\text { Meramec confluence, Mo. }\end{array}$ & 382756 & 902501 & -- & USEPA & Salem & 1985 & 1 \\
\hline 100 & $\begin{array}{l}\text { Sugar Creek near mouth, } \\
\text { Mo. }\end{array}$ & 382813 & 902543 & -- & USEPA & Salem & 1983 & 3 \\
\hline 101 & $\begin{array}{l}\text { Meramec River south of } \\
\text { Eureka, Mo. }\end{array}$ & 382821 & 903933 & -- & USEPA & Salem & $1980-88$ & 11 \\
\hline 102 & $\begin{array}{l}\text { Saline Creek before } \\
\text { confluence of Sugar Creek, } \\
\text { Mo. }\end{array}$ & 382825 & 902549 & -- & USEPA & Salem & 1983 & 3 \\
\hline 103 & $\begin{array}{l}\text { Meramec River } 2 \text { miles } \\
\text { below Pacific, Mo. }\end{array}$ & 382848 & 904312 & -- & USEPA & Salem & 1984 & 1 \\
\hline
\end{tabular}


Table 8. Site and basin characteristics of biological-tissue sampling sites--Continued

$\left[\mathrm{mi}^{2}\right.$, square miles; WY70-90, water years 1970-1990; --, data unavailable; ODEQ, Oklahoma Department of Environmental Quality; ADPCE, Arkansas Department of Pollution Control and Ecology; USEPA, U.S. Environmental Protection Agency; KDHE, Kansas Department of Health and Environment; USCOE, U.S. Army Corps of Engineers]

\begin{tabular}{|c|c|c|c|c|c|c|c|c|}
\hline $\begin{array}{c}\text { Site } \\
\text { number }\end{array}$ & Site name & Latitude & Longitude & $\begin{array}{l}\text { Drainage area } \\
\qquad\left(\mathrm{mi}^{2}\right)\end{array}$ & $\begin{array}{l}\text { Collecting } \\
\text { agency }\end{array}$ & $\begin{array}{l}\text { Physio- } \\
\text { graphic } \\
\text { area }^{1}\end{array}$ & $\begin{array}{l}\text { Period of } \\
\text { record } \\
(\text { WY70-90) }\end{array}$ & $\begin{array}{c}\text { Number } \\
\text { of } \\
\text { samples }\end{array}$ \\
\hline 104 & $\begin{array}{l}\text { Meramec River upstream } \\
\text { I44 Bridge at Times Beach, } \\
\text { Mo. }\end{array}$ & 383013 & 903525 & -- & USEPA & Salem & 1983 & 4 \\
\hline 105 & $\begin{array}{l}\text { Meramec River below } \\
\text { Fenton upstream of } \\
\text { Marina, Mo. }\end{array}$ & 383030 & 902610 & -- & USEPA & Salem & 1983 & 3 \\
\hline 106 & $\begin{array}{l}\text { Meramec River at } \\
\text { Fenton, Mo. }\end{array}$ & 383051 & 902603 & -- & USEPA & Salem & $1984-85$ & 2 \\
\hline 107 & $\begin{array}{l}\text { Meramec River down } \\
\text { stream of Glencoe, Mo. }\end{array}$ & 383232 & 903507 & -- & USEPA & Salem & 1983 & 4 \\
\hline 108 & $\begin{array}{l}\text { Meramec River just below } \\
\text { Glencoe, Mo. }\end{array}$ & 383232 & 903703 & -- & USEPA & Salem & 1984 & 1 \\
\hline 109 & $\begin{array}{l}\text { Meramec River upstream of } \\
\text { Valley Park Bridge, Mo. }\end{array}$ & 383240 & 903030 & -- & USEPA & Salem & 1983 & 3 \\
\hline 110 & $\begin{array}{l}\text { Meramec River at Fishpot } \\
\text { Creek, Mo. }\end{array}$ & 383241 & 902948 & -- & USEPA & Salem & 1984 & 1 \\
\hline 111 & $\begin{array}{l}\text { Chrysler car plant industrial } \\
\text { waste, Mo. }\end{array}$ & 383300 & 902735 & -- & USEPA & Salem & 1983 & 1 \\
\hline 112 & $\begin{array}{l}\text { Kiefer Creek near } \\
\text { Castlewood, Mo. }\end{array}$ & 383305 & 903233 & -- & USEPA & Salem & 1984 & 1 \\
\hline 113 & $\begin{array}{l}\text { Fishpot Creek at Hanna } \\
\text { Road Bridge, St. Louis, Mo. }\end{array}$ & 383308 & 903041 & -- & USEPA & Salem & 1983 & 3 \\
\hline 114 & $\begin{array}{l}\text { Grand Glaize Creek } \\
\text { between Marshall Road } \\
\text { Bridge \& Meramec River, } \\
\text { Mo. }\end{array}$ & 383314 & 902941 & -- & USEPA & Salem & 1984 & 1 \\
\hline 115 & $\begin{array}{l}\text { Grand Glaize Creek at } \\
\text { Marshall Road Bridge, } \\
\text { St. Louis, Mo. }\end{array}$ & 383316 & 902751 & -- & USEPA & Salem & 1983 & 3 \\
\hline 116 & $\begin{array}{l}\text { Hamilton Creek near } \\
\text { Glencoe, Mo. }\end{array}$ & 383325 & 903851 & -- & USEPA & Salem & 1984 & 1 \\
\hline 117 & $\begin{array}{l}\text { Meramec River near } \\
\text { Kirkwood wastewater } \\
\text { treatment intake, Mo }\end{array}$ & 383334 & 902645 & -- & USEPA & Salem & 1983 & 4 \\
\hline 118 & $\begin{array}{l}\text { Grand Glaize at Carmen } \\
\text { Road Bridge, Mo. }\end{array}$ & 383430 & 902814 & -- & USEPA & Salem & 1983 & 3 \\
\hline 119 & $\begin{array}{l}\text { Sugar Creek near Ozark } \\
\text { View subdivision, St. Louis, } \\
\text { Mo. }\end{array}$ & 383447 & 902732 & -- & USEPA & Salem & 1983 & 3 \\
\hline 120 & $\begin{array}{l}\text { Grand Glaize Creek below } \\
\text { Sulphur Springs Road, Mo. }\end{array}$ & 383533 & 903108 & -- & USEPA & Salem & 1983 & 3 \\
\hline
\end{tabular}

${ }^{1}$ Springfield, Springfield Plateau; Boston, Boston Mountains; Salem, Salem Plateau; St. Francois, St. Francois Mountains.

${ }^{2}$ Original site name is "Wilson Creek downstream"; reference to South Creek added for clarification.

${ }^{3}$ Original site name is "Wilson Creek upstream"; reference to South Creek added for clarification. 